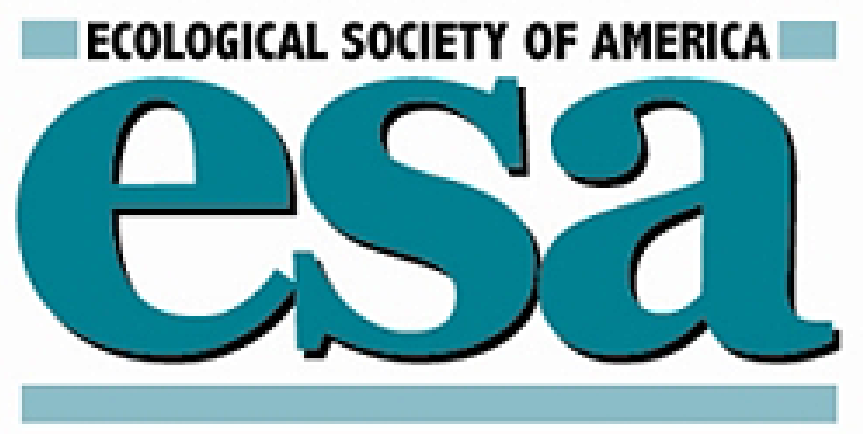

Plant-Soil Processes in Eriophorum Vaginatum Tussock Tundra in Alaska: A Systems Modeling Approach

Author(s): P. C. Miller, P. M. Miller, M. Blake-Jacobson, F. S. Chapin, K. R. Everett, D. W.

Hilbert, J. Kummerow, A. E. Linkins, G. M. Marion, W. C. Oechel, S. W. Roberts and L. Stuart Source: Ecological Monographs, Vol. 54, No. 4 (Dec., 1984), pp. 361-405

Published by: Ecological Society of America

Stable URL: http://www.jstor.org/stable/1942593

Accessed: $12 / 03 / 2014$ 10:51

Your use of the JSTOR archive indicates your acceptance of the Terms \& Conditions of Use, available at http://www.jstor.org/page/info/about/policies/terms.jsp

JSTOR is a not-for-profit service that helps scholars, researchers, and students discover, use, and build upon a wide range of content in a trusted digital archive. We use information technology and tools to increase productivity and facilitate new forms of scholarship. For more information about JSTOR, please contact support@jstor.org. 


\title{
PLANT-SOIL PROCESSES IN ERIOPHORUM VAGINATUM TUSSOCK TUNDRA IN ALASKA: A SYSTEMS MODELING APPROACH ${ }^{1}$
}

\author{
P. C. Miller, ${ }^{2}$ P. M. Miller, AND M. Blake-JACobson \\ Systems Ecology Research Group, San Diego State University,
} San Diego, California 92182 USA

\section{F. S. CHAPIN, III}

Institute of Arctic Biology, University of Alaska, Fairbanks, Alaska 99701 USA

\section{K. R. EVERETT}

Institute of Polar Studies, Ohio State University, Columbus, Ohio 43210 USA

D. W. Hilbert AND J. Kummerow

Systems Ecology Research Group, San Diego State University, San Diego, California 92182 USA

A. E. LINKINS

Biology Department, Virginia Polytechnic Institute, Blacksburg, Virginia 24061 USA

G. M. Marion, W. C. Oechel, and S. W. Roberts Systems Ecology Research Group, San Diego State University, San Diego, California 92182 USA

AND

\section{StUART}

Biology Department, Virginia Polytechnic Institute, Blacksburg, Virginia 24061 USA

\begin{abstract}
The Arctic Tundra Simulator (ARTUS) is a computer-based simulation model of $E r$ iophorum vaginatum tussock tundra ecosystems found in north central Alaska. ARTUS simulates the annual patterns of heat and water balance, carbon fixation, plant growth, and nitrogen and phosphorus cycling. ARTUS runs in 1-d time steps for a growing season from 1 May to 17 September and is intended to run for several years. The abiotic section of ARTUS encodes the seasonal input of the environmental driving variables and calculates the resultant thermal and water regimes to define the heat and water environments for the tussock tundra system. The primary driving variables are daily total solar radiation, air temperature, precipitation, surface albedo, wind, and sky conditions. The soil compartment contains three organic horizons, which are recognized by their state of physical and chemical decomposition, and one mineral horizon. Six vascular plant species and four moss species are simulated. The model has seven compartments for each vascular plant species: total nonstructura carbohydrates, total nitrogen, total phosphorus, leaves grown in the current season, leaves grown in previous years, conducting and storage stems plus roots, and absorbing roots. In ARTUS the functiona unit of the plant is the shoot system or ramet. Each shoot system consists of leaves, stems, fine roots (which do not have secondary growth and have a limited life-span), and larger roots, which have secondary growth and an extended life-span. Although plant processes are based on individual shoots, the ARTUS model as a whole is based on a square metre of ground. Values per square metre are calculated from the values per shoot by multiplying by the shoot density of each species.

The model was validated by comparing calculated and measured peak season biomasses and nutrient contents, and the seasonal progression of environmental processes, biomass, carbohydrate contents, and nutrient contents. ARTUS successfully simulated the seasonality of the physical environment, but simulated thaw depths were deeper than those measured at all sites. The simulated value for total vascular plant production was $77 \%$ of the measured value. The simulated values for ecosystem respiration for Eagle Creek were within the range of measured values. Simulations with ARTUS indicated different patterns of growth and different storage-carbohydrate levels in deciduous shrubs, evergreen shrubs, and graminoids. The simulated seasonal course of net primary production of vascular plants and mosses was similar to the pattern measured at Eagle Creek.
\end{abstract}

\footnotetext{
${ }^{1}$ Manuscript received 7 March 1983; revised 10 February 1984; accepted 12 February 1984.

2 Dr. P. C. Miller died in July 1982.
} 
Sensitivity analysis using ARTUS indicated that the tussock tundra is more sensitive to external environmental factors, such as increased temperature, than to internal ecosystem variables. The development of ARTUS was limited by the unavailability of data on whole-plant carbon balance including root and stem respiration. More data are also needed on decomposition processes and nitrogen and phosphorus cycling. Adequate climatological data for northern Alaska are needed for extensive validations of the model. While caution should be used in basing managerial decisions on model simulations, ARTUS can be used to identify and quantify the magnitude and direction of plant responses to changes in state variables in the model.

Key words: ecosystem model; Eriophorum vaginatum; mineralization; photosynthesis; plant-soil processes; productivity; tussock tundra.

\section{INTRODUCTION}

\section{Problem and objectives}

The Arctic is incurring increasing disturbance with the development of its large mineral and energy resources. Past experience indicates that arctic tundra is extremely sensitive to disturbance and slow to recover because of the short season available for plant growth and the possibility of soil subsidence and erosion following melting of permafrost (Webber and Ives 1978). Increasing exploration of the Arctic and the desire to preserve its wilderness character dictate that management alternatives be evaluated based on an understanding of biological processes in arctic ecosystems. This understanding should be formalized in a framework that is quantitative, predictive, and integrated.

In the United States, integrated research on the ecology of arctic areas began in the late 1950s at Cape Thompson in northwestern Alaska, with the Project Chariot program sponsored by the Atomic Energy Commission. The program documented major ecosystem components but was not oriented to quantifying important underlying plant and soil processes (Wilimovsky and Wolfe 1966). During the early 1970s the United States Tundra Biome Program of the International Biological Programme concentrated on process-oriented research on primary production, decomposition, and consumption in wet-meadow tundra near Barrow, Alaska (Brown et al. 1980).

In 1974 at the conclusion of the International Biological Programme (IBP), separate models of photosynthesis and growth of vascular plants and mosses and preliminary models of decomposition and mineral cycling existed (Miller and Tieszen 1972, Bunnell et al. 1975, Miller et al. 1976, Lawrence et al. 1978, Miller et al. 1978, Stoner et al. 1978a, b). The models developed during the IBP lacked sufficient detail and breadth to be useful in predicting the effects of diverse perturbations and did not attempt to link plant and soil processes. At the conclusion of the IBP it was agreed that the best time scale for simulation modeling was a 1-2 yr period using 1-d time steps. Processes in shorter time periods were hard to relate to the ecosystem level, and those in longer time periods were hard to test.
After the termination of IBP, our research concentrated on plant-soil interactions at Eagle Creek, Alaska, and was funded by the United States Department of Energy Office of Environmental Programs. A simulation model of organic decomposition and mineralization of nitrogen, phosphorus, and calcium was completed based on the research during the IBP (Barkley et al. 1978). This model was expanded to include a moss layer. The existing models of plant and soil processes were collated into one detailed mechanistic computer program, which was later revised and developed in several workshops.

The reseach on primary production, decomposition, and mineralization processes and the development of the Arctic Tundra Simulator (ARTUS) model focused on ecosystem functions and on the effects of energy exploration and development. The model was based on data obtained over a $2-5$ yr period from field research under ambient and perturbed conditions and from laboratory studies. Field measurements were made at several geographic locations in the Alaskan Arctic.

The research program focused on the Eriophorum vaginatum tussock tundra ecosystem type, one of the most widespread circumpolar ecosystems and one closely associated with Alaskan energy resources. About $16 \%$ of the $5.7 \times 10^{6} \mathrm{~km}^{2}$ of ice-free land area in the arctic and $\approx 80 \%$ of the $0.22 \times 10^{6} \mathrm{~km}^{2}$ of tundra in Alaska north of the Arctic Circle are covered by tussock tundra (Miller 1981). Known coal reserves underlie $36-40 \%$ of the tussock tundra in Alaska. It is estimated that $50 \%$ of the total oil resources remaining within the jurisdiction of the United States occur in the arctic (Polar Research Board 1982). Access routes to these reserves cross tussock tundra areas. Thus an understanding of the functioning of this ecosystem is of economic importance.

The objectives of this paper are to document the ARTUS model, to summarize the research that provided the parameter values used to develop the model, and to describe its validation. The results of simulations using ARTUS can provide insight on the recovery of tussock tundra after perturbation.

\section{Site description}

The model was developed from research carried out in tussock tundra at Eagle Creek, near mile 101 on the 
Steese Highway in north-central Alaska (Fig. 1). The site was selected because it is relatively accessible from Fairbanks and the University of Alaska campus, which facilitates logistic and laboratory support. The site, described by Wein and Bliss (1973, 1974), Haugen and Brown (1978), Oberbauer and Miller (1979, 1981), Chapin et al. (1979), and Miller (1982), is on a sloping ridge at $750 \mathrm{~m}$ elevation. The mineral soil is poorly drained and is overlain by an organic soil horizon $\approx 30$ $\mathrm{cm}$ thick. The site is surrounded by spruce forest; tussock tundra probably exists in the area because of the poorly drained mineral soil. Six sites in other parts of Alaska were selected for validating the model (Fig. 1, Table 1). Four sites were selected along the TransAlaskan Pipeline System (TAPS) haul road at Old Man Camp, Timberline, Toolik Lake, and Sagwon. The TAPS haul road provides a south-north transect from the Yukon River through the Brooks Range to the coastal plain of the Arctic Ocean. The two additional sites were in the Ogotoruk Valley at Cape Thompson in northwestern Alaska. One site is on the east side of Ogotoruk Creek at the east end of the long airfield runway. The second was on the west side of Ogotoruk Creek on the slope between the creek and the adjacent ridge. Both sites are in extensive areas of tussock tundra. The validation sites cover a broad geographic range and have been studied in previous investigations.

\section{Model Description and Data Base}

\section{General organization and operation of the model}

The Arctic Tundra Simulator (ARTUS) ${ }^{3}$ describes annual patterns of heat and water balance, carbon fixation, plant growth, and nitrogen and phosphorus cycling in tussock tundra. The model assumes a composite vegetation of $60 \%$ tussock subunits and $40 \%$ intertussock, as measured at Eagle Creek, but does not make separate calculations for each subunit. Calculations are on a square metre basis. ARTUS runs in 1-d time steps for a growing season from 1 May to 17 September and can run for any number of years. Some state variables are given initial values once at the beginning of the simulation, and other state variables are given the same initial values at the beginning of each new year. The daily sequence of calculations is: environment, soil processes, nutrient uptake, moss processes, and vascular plant processes. Two alternative soil process submodels exist; only one is used for a given simulation. The enzyme submodel uses decom-

${ }^{3}$ See ESA Supplementary Publication Service Document No. 8417 for a 55-page listing of the ARTUS program and 30 pages of information on locations and labels of variables for ARTUS equations. For a copy of this document, contact the second author, P. M. Miller, or order from the Ecological Society of America, Cornell University, Ithaca, New York 14853 USA.

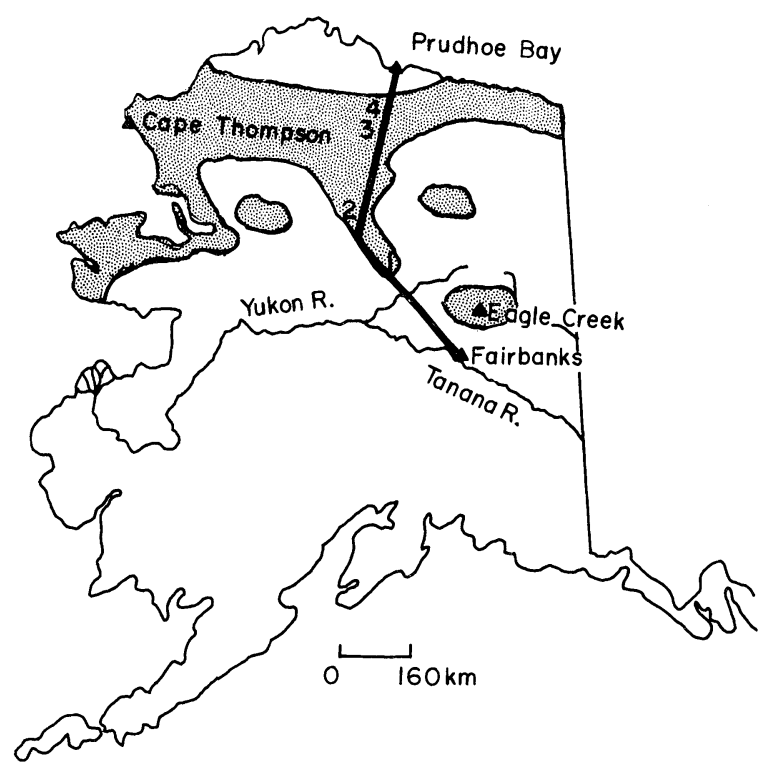

FIG. 1. Location of study areas in Alaska: Cape Thompson, Eagle Creek, and along the TAPS haul road at (1) Old Man Camp, (2) Timberline, (3) Toolik Lake, and (4) Sagwon. Stippling indicates areas of tussock tundra.

position rates of the individual soil organic components to determine nitrogen mineralization. The soil incubation submodel predicts net nitrogen mineralization from laboratory measurements of potential mineralizable nitrogen.

Six vascular plant species and four moss species are simulated. The six vascular species constitute $\approx 90 \%$ of the biomass in tussock tundra (Fig. 2). Mosses have one compartment of green biomass for each moss type. A grass species, which in the field is often a species of Arctagrostis or Calamagrostis, is also included in the model, but space limitations in the computer graphics allow presentation of the results for only six vascular plant species. The soil contains three organic horizons, which are recognizable by their state of physical and chemical decomposition, and one mineral horizon.

\section{Vascular plants}

Species covered. - The dominant plant in tussock tundra is Eriophorum vaginatum L. spissum (Fern) Hult. (cotton grass), a tussock-forming sedge (Fig. 2E) with a circumpolar distribution. It has culms that reach a height of $10 \mathrm{~cm}$ and thick roots that extend more or less straight down to the freeze-thaw line and absorb nutrients from all soil layers (Chapin et al. 1979). A tiller produces $\approx 2$ new leaves/yr and may produce an axillary tiller. After $4 \mathrm{yr}$, tillers flower and then senesce (Fetcher and Shaver 1983). Roots and most of the leaf mass die back each year. Tussocks occupy $\approx 60 \%$ of the total surface area and show various degrees of invasion by mosses and evergreen shrubs. The mosses Polytrichum commune Hedw. and Dicranum elonga- 
TABLE 1. General environmental and vegetation data on the experimental and validation sites.

\begin{tabular}{|c|c|c|c|c|c|c|c|c|}
\hline & \multirow{3}{*}{$\begin{array}{r}\text { Eagle } \\
\text { Creek }\end{array}$} & \multicolumn{4}{|c|}{ Trans-Alaskan Pipeline } & \multirow{2}{*}{\multicolumn{2}{|c|}{ Cape Thompson }} & \multirow[b]{3}{*}{ Reference } \\
\hline & & \multirow[b]{2}{*}{ Old Man } & \multirow[b]{2}{*}{ Timberline } & \multirow{2}{*}{$\begin{array}{l}\text { Toolik } \\
\text { Lake }\end{array}$} & \multirow[b]{2}{*}{ Sagwon } & & & \\
\hline & & & & & & \multicolumn{2}{|c|}{ East West } & \\
\hline Latitude & $65^{\circ} 26^{\prime}$ & $66^{\circ} 27^{\prime}$ & $68^{\circ} 02^{\prime}$ & $68^{\circ} 39^{\prime}$ & $69^{\circ} 25^{\prime}$ & $68^{\circ} 05^{\prime}$ & $68^{\circ} 05^{\prime}$ & $\begin{array}{l}\text { Wilimovsky and Wolfe } \\
\text { (1966) }\end{array}$ \\
\hline Elevation (m) & 750 & 488 & 790 & 635 & 300 & 190 & 290 & $\begin{array}{l}\text { Haugen and Brown } \\
\text { (1978) }\end{array}$ \\
\hline $\begin{array}{l}\text { Annual mean air tem- } \\
\text { perature }\left({ }^{\circ} \mathrm{C}\right)\end{array}$ & -6.9 & -7 & -9 & -12 & -12.5 & -7.3 & -7.3 & $"$ \\
\hline $\begin{array}{l}\text { July mean air tem- } \\
\text { perature }\left({ }^{\circ} \mathrm{C}\right)\end{array}$ & 12.3 & 14.2 & 14.5 & 10 & 10 & 8.3 & 8.3 & $"$ \\
\hline $\begin{array}{l}\text { August thaw depth } \\
\text { (cm) }\end{array}$ & $62 \pm 1$ & $43 \pm 1$ & $\cdots$ & $44 \pm 2$ & $47 \pm 2$ & $60 \pm 1$ & $57 \pm 1$ & $\begin{array}{l}\text { P. C. Miller (personal } \\
\text { observation) }\end{array}$ \\
\hline $\begin{array}{l}\text { Length of thaw sea- } \\
\text { son (days) }\end{array}$ & 160 & 161 & 160 & 129 & 129 & 90 & 90 & $\begin{array}{l}\text { Haugen and Brown } \\
\text { (1978) }\end{array}$ \\
\hline $\begin{array}{l}\text { Thaw degree days } \\
\text { before } 1 \text { August }\end{array}$ & $\ldots$ & 975 & 870 & 420 & 420 & $\cdots$ & $\cdots$ & " \\
\hline $\begin{array}{l}\text { Unfrozen precipita- } \\
\text { tion }(\mathrm{mm})\end{array}$ & 226 & 214 & 181 & 87 & 145 & 152 & 152 & $"$ \\
\hline \multicolumn{9}{|l|}{ Cover $(\%)$} \\
\hline Betula nana & $6 \pm 3$ & $1 \pm 0$ & $30 \pm 7$ & $4 \pm 1$ & $7 \pm 1$ & $42 \pm 8$ & $22 \pm 9$ & $\begin{array}{l}\text { P. C. Miller et al. (per- } \\
\text { sonal observation) }\end{array}$ \\
\hline Vaccinium uliginosum & $6 \pm 1$ & $11 \pm 1$ & $2 \pm 1$ & 0 & 0 & 0 & 0 & $"$ \\
\hline Ledum palustre & $4 \pm 0$ & $4 \pm 1$ & $1 \pm 1$ & $4 \pm 0$ & $4 \pm 1$ & $4 \pm 1$ & $22 \pm 5$ & $"$ \\
\hline Vaccinium vitis-idaea & $4 \pm 0$ & $4 \pm 1$ & 0 & $3 \pm 0$ & $4 \pm 0$ & 0 & $2 \pm 1$ & $"$ \\
\hline Eriophorum vaginatum & $20 \pm 2$ & $2 \pm 1$ & 0 & $16 \pm 3$ & $15 \pm 0$ & $51 \pm 8$ & $21 \pm 8$ & $"$ \\
\hline Carex bigelowii & $7 \pm 1$ & $8 \pm 1$ & $2 \pm 0$ & $3 \pm 0$ & $2 \pm 0$ & $18 \pm 8$ & $13 \pm 4$ & $"$ \\
\hline Salix pulchra & 0 & 0 & $12 \pm 1$ & $5 \pm 2$ & $3 \pm 1$ & $51 \pm 8$ & $21 \pm 8$ & $"$ \\
\hline Sphagnum capillaceum & 21 & $33 \pm 5$ & $1 \pm 1$ & $24 \pm 4$ & $17 \pm 4$ & $19 \pm 8$ & $32 \pm 10$ & $\begin{array}{l}\text { Alpert and Oechel (1982), P. C. } \\
\text { Miller et al. (personal } \\
\text { observation) }\end{array}$ \\
\hline Dicranum elongatum & 7 & $6 \pm 2$ & $10 \pm 2$ & $7 \pm 2$ & $16 \pm 4$ & $14 \pm 4$ & $15 \pm 5$ & $"$ \\
\hline Litter & $\cdots$ & $31 \pm 3$ & $21 \pm 3$ & $32 \pm 2$ & $34 \pm 4$ & $40 \pm 10$ & $90 \pm 11$ & P. C. Miller et al. (per- \\
\hline Bare ground & 0 & 0 & 0 & $2 \pm 1$ & $0 \pm 0$ & $76 \pm 19$ & $18 \pm 7$ & sonal observation) \\
\hline
\end{tabular}

tum Schleich. H. Schwaegr. often occur on the tussocks. Intertussock spaces are often dominated by Sphagnum species. Nomenclature follows Hulten (1968).

Betula nana L. Hult., also called B. exilis (dwarf birch), is a circumpolar decumbent dwarf shrub $\approx 30$ $\mathrm{cm}$ high (Fig. 2A) that annually produces six to seven leaves on long shoots and two to three leaves on each short shoot (Sorensen 1941, Murray and Miller 1982). The leaves are dropped by late August. Most B. nana roots are in the upper organic horizon, but some extend down to the freeze-thaw line (Kummerow and Russell 1980).

Vaccinium uliginosum L. alpinum (Bigel) Hult. (blueberry) is another circumpolar deciduous dwarf shrub (Fig. 2B) common in tussock tundra. It has many branches and a deep fibrous root system (Kummerow and Russell 1980).

Ledum palustre L. decumbens (Ait.) Hult. is a low, sparsely branching, evergreen shrub (Fig. 2C) that is common where water is available (Oberbauer and Miller 1982). It is abundant in heaths and occurs to $\approx 1800$ $m$ elevation in mountains (Hulten 1968). Each year, a stem produces $\approx 14$ new leaves which are $1-2 \mathrm{~cm}$ long (Shaver 1981). A stem typically grows straight for three seasons before flowering and branching into three new stems. Ledum palustre roots extend to the mineral soil and have a distribution similar to those of $B$. nana. In addition $L$. palustre has adventitious roots along stems that are buried in the organic mat (Kummerow and Russell 1980).

Vaccinium vitis-idaea L. minus (Lodd.). Hult. (lingonberry) is a creeping evergreen shrub $2 \mathrm{~cm}$ high (Fig. 2D) that is rooted solely in the upper organic horizon.

Carex bigelowii Torr., a common circumpolar sedge $\approx 15 \mathrm{~cm}$ tall (Fig. 2F), produces four new leaves each year and spreads by runners (Murray and Miller 1982). It is rooted primarily in the upper organic horizon, but some roots extend into the second horizon.

Arctagrostis latifolia (R. Br.) Griseb. (polar grass) was used to represent the grasses in the ARTUS model. It grows to a height of $25 \mathrm{~cm}$ in wet meadows, along rivers, and in the tundra (Hulten 1968). It spreads by a creeping, branching rhizome and has most of its roots in the upper organic soil horizon. Arctagrostis latifolia is rare in tussock tundra that is underlain by an organic horizon, is slightly more common in tussock tundra where the mineral soil is close to the surface, but rapidly becomes abundant and conspicuous after nutrient 


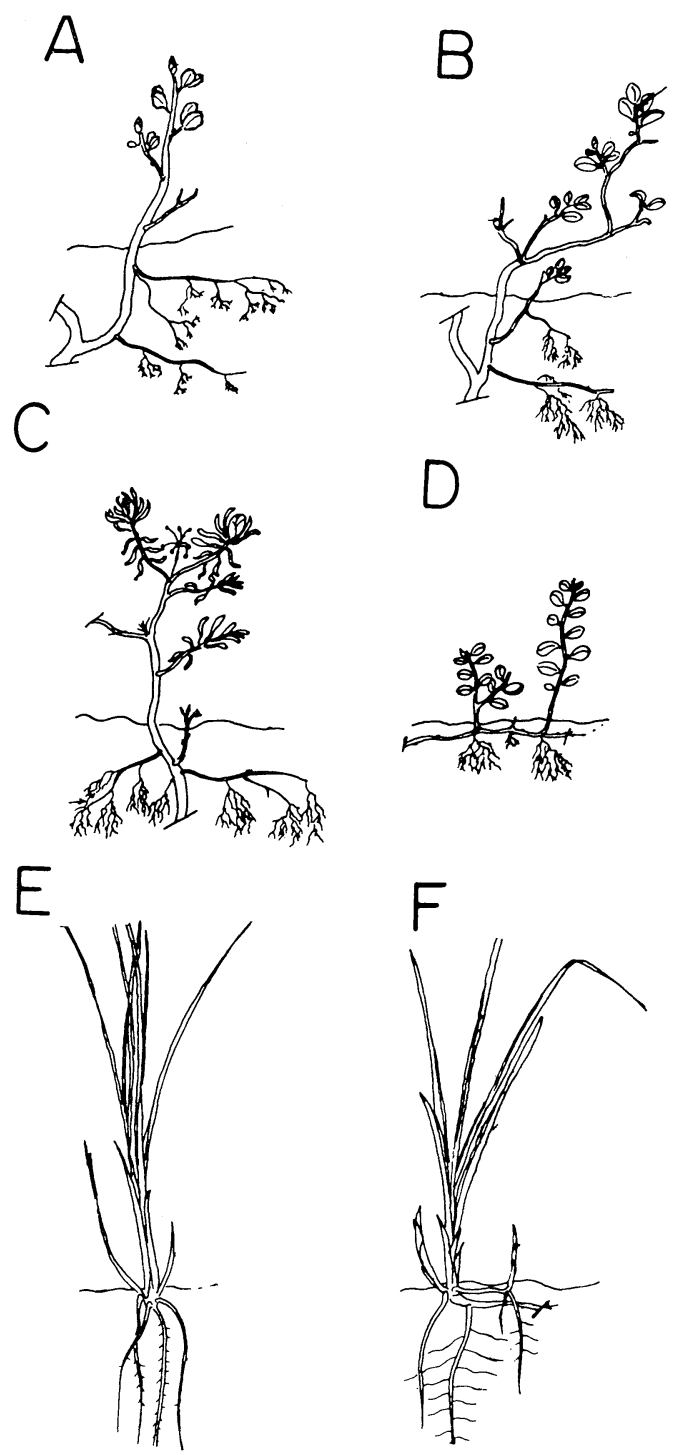

FIG. 2. Semischematic drawings of six tundra plants, the deciduous species (A) Betula nana and (B) Vaccinium uliginosum, the evergreen shrubs (C) Ledum palustre and (D) Vaccinium vitis-idaea, and the sedges (E) Eriophorum vaginatum and $(\mathrm{F})$ Carex bigelowii. Drawings $\approx 40 \%$ natural size.

additions, whether by fertilizer or decaying animal carcasses (McKendrick et al. 1978).

Growth. - The model has seven compartments for each vascular plant species: total nonstructural carbohydrates, total nitrogen, total phosphorus, leaves grown in the current season, leaves grown in previous years, conducting and storage stems plus roots, and absorbing roots (Table 2, Fig. 3). In ARTUS the functional unit of the plant is the shoot system or ramet. Each shoot system consists of leaves; stems; rhizomes; fine roots, which do not have secondary growth and have a limited life span; and larger roots, which have secondary growth and an unlimited life span. The shoot system is defined as the functional unit because it is able to grow and reproduce when separated from the parent plant. Each shoot system can contain several shoots. Individual shoots are defined as actively growing foliated stems originating from terminal or axillary buds. The units in each vascular plant compartment are expressed as grams dry mass per shoot because shoots are easily recognized and can be counted nondestructively in the field.

Although plant processes are based on individual shoots, the ARTUS model as a whole is based on a square metre of ground. Values per square metre are calculated from the values per shoot by multiplying by the shoot density (GPM2) of each species.

The total nonstructural carbohydrate compartment is a pool of sugars and storage carbohydrates that is allocated to the three biomass compartments: leaves, stems, and roots. Daily growth processes are allowed to use up to $90 \%$ of the sugars and storage carbohydrate in the pool; a small amount remains in the pool at all times.

The nitrogen and phosphorus compartments are contents of these elements in the whole shoot. These two compartments are updated each day by adding nitrogen and phosphorus uptake and subtracting loss through death (Tables 3 and 4). Before calculating nutrient uptake, the root length within each soil horizon is calculated from root biomass in that horizon using a root length : root mass ratio (Miller et al. 1982). The values for root length are minimum estimates because of the difficulty of excavating roots in tussock tundra and because the data do not include the hyphae of mycorrhizal fungi, which are abundant on roots of the dwarf shrubs. Therefore the root length of each species is multiplied by a nutrient uptake adjustment factor that accounts for the loss of roots during excavation and increases nutrient uptake to levels measured in the field (L. Stuart and P. C. Miller, personal observation). When plant parts die, certain fractions of the dying biomass contain nitrogen and phosphorus (LFNDETH, LFPDETH) that fall with the dying part. The remaining fractions are kept in the plant. Nutrient uptake is discussed later.

Growth is calculated for each biomass compartment (Table 3). New leaves are those grown in the current season. For evergreen shrubs old leaves are those produced in previous years. Leaf growth begins in early summer after the site has been snow-free for $7 \mathrm{~d}$ and after the heat sum of the air or soil surface exceeds a minimum value (HTMIN) which is estimated for each species (Gilardi 1984; Appendix 2: Table A1). To find daily potential leaf growth (POTLFGRO), the maximum daily growth rate (LFGROMX) is modified by a temperature function (LFGROTF) and by a sigmoidal function such that rates are higher in early season and approach zero as new-leaf biomass approaches peak season biomass (Table 3: Eq. 1). Stems include oldand new-stem biomass. Potential stem growth in the 
TABLE 2. Initial values (early season) for the vascular plant compartments at Eagle Creek. Compartments are defined in Model description and data base: growth.

\begin{tabular}{|c|c|c|c|c|c|c|c|c|c|c|}
\hline \multirow[b]{3}{*}{ Compartment } & \multirow{3}{*}{$\begin{array}{l}\text { Program } \\
\text { name* }\end{array}$} & \multirow{2}{*}{\multicolumn{6}{|c|}{ Value }} & \multicolumn{2}{|c|}{ Confidence $\ddagger$} & \multirow[b]{3}{*}{ Reference } \\
\hline & & & & & & & & \multirow{2}{*}{$\begin{array}{l}\text { Eagle } \\
\text { Creek }\end{array}$} & \multirow{2}{*}{$\begin{array}{l}\text { Tus- } \\
\text { sock } \\
\text { tun- } \\
\text { dra }\end{array}$} & \\
\hline & & B.n.† & V.u. & L.d. & V.v. $-i$ & E.v. & C.b. & & & \\
\hline Leaf dry mass (mg/shoot) & & 1 & 1 & 50 & 64 & 5 & 1 & $\mathrm{~b}$ & $\mathrm{~b}$ & $\begin{array}{c}\text { Shaver and Cutler } \\
(1979)\end{array}$ \\
\hline $\begin{array}{l}\text { Stem and large root dry mass } \\
(\mathrm{mg} / \mathrm{shoot})\end{array}$ & & 100 & 115 & 64 & 45 & 65 & 900 & c & c & Miller et al. (1982) \\
\hline $\begin{array}{l}\text { Absorbing root dry mass (mg/ } \\
\text { shoot) }\end{array}$ & & 0.01 & 0.01 & 0.01 & 0.01 & 0.01 & 0.01 & c & $\mathrm{d}$ & Miller et al. (1982) \\
\hline $\begin{array}{l}\text { Leaf storage carbohydrate } \\
\left(\mathrm{CH}_{2} \mathrm{O}, \mathrm{mg} / \mathrm{g} \text { dry mass }\right)\end{array}$ & & 160 & 160 & 100 & 100 & 300 & 100 & $\mathrm{~d}$ & d & Estimate \\
\hline $\begin{array}{l}\text { Stem storage carbohydrate } \\
\left(\mathrm{CH}_{2} \mathrm{O}, \mathrm{mg} / \mathrm{g} \text { dry mass }\right)\end{array}$ & & 160 & 160 & 50 & 100 & 300 & 100 & d & d & Estimate \\
\hline $\begin{array}{l}\text { Root storage carbohydrate } \\
\left(\mathrm{CH}_{2} \mathrm{O}, \mathrm{mg} / \mathrm{g} \text { dry mass }\right)\end{array}$ & & 160 & 160 & 100 & 100 & 300 & 100 & $\mathrm{~d}$ & $\mathrm{~d}$ & Estimate \\
\hline Leaf nitrogen (mg/g dry mass) & & 37 & 37 & 10 & 15 & 25 & 20 & $\mathrm{~b}$ & $\mathrm{~b}$ & Stuart and Miller (1982) \\
\hline Stem nitrogen (mg/g dry mass) & & 9 & 9 & 8 & 15 & 10 & 20 & $\mathrm{~b}$ & $\mathrm{~b}$ & Stuart and Miller (1982) \\
\hline Root nitrogen (mg/g dry mass) & & 10 & 10 & 20 & 10 & 25 & 20 & $\mathrm{~b}$ & $\mathrm{~b}$ & Estimate \\
\hline $\begin{array}{l}\text { Shoot density (shoots } / \mathrm{m}^{2} \text { ) } \\
\text { Absorbing root distribution }\end{array}$ & $\begin{array}{l}\text { GPM2 } \\
\text { RTDIS }\end{array}$ & 46 & 46 & 570 & 1434 & 984 & 100 & $\mathrm{~b}$ & $\mathrm{~b}$ & Stoner et al. (1982) \\
\hline layer) Fibric & & 0.70 & 0.70 & 0.70 & 1.00 & 0.50 & 0.80 & & & $\begin{array}{l}\text { Kummerow and Rus- } \\
\text { sell (1980) }\end{array}$ \\
\hline Hemic & & 0.15 & 0.15 & 0.15 & 0 & 0.20 & 0.20 & & & $\begin{array}{l}\text { Kummerow and Rus- } \\
\text { sell (1980) }\end{array}$ \\
\hline Sapric & & 0.10 & 0.10 & 0.10 & 0 & 0.15 & 0 & & & $\begin{array}{l}\text { Kummerow and Rus- } \\
\text { sell (1980) }\end{array}$ \\
\hline Mineral & & 0.05 & 0.05 & 0.05 & 0 & 0.15 & 0 & & & $\begin{array}{l}\text { Kummerow and Rus- } \\
\text { sell (1980) }\end{array}$ \\
\hline $\begin{array}{l}\text { Nutrient adjustment factor } \\
(\mathrm{m} / \mathrm{m})\end{array}$ & MYCO & 3.2 & 1.6 & 4 & 8 & 4 & 1 & d & d & Estimate \\
\hline Specific leaf mass & GLFM2LF & 80 & 77 & 235 & 117 & 123 & 80 & b & $\mathrm{b}$ & Estimate \\
\hline
\end{tabular}

* See Appendix 1 for definitions.

$\dagger$ B.n. = Betula nana, V.u. = Vaccinium uliginosum, L.d. = Ledum palustre, V.v.-i. = Vaccinium vitis-idaea, C.b. $=$ Carex bigelowii, E.v. = Eriophorum vaginatum.

$¥$ Indication of degree of confidence in the value as representing conditions at the indicated sites.

$\mathrm{a}=$ value believed representative within $\pm 25 \%$; confident.

$\mathrm{b}=$ value believed representative within $\pm 50 \%$; mildly unconfident.

$\mathrm{c}=$ value believed representative within $\pm 100 \%$; unconfident

$\mathrm{d}=$ value believed not representative within $\pm 100 \%$; i.e., no data whatsoever.

present ARTUS model is set equal to potential leaf growth (Table 3: Eq. 2).

The root biomass compartment consists of roots with diameters $<1.0 \mathrm{~mm}$. This compartment is subdivided to account for roots in the four soil horizons. Roots grow within a given horizon whenever soil temperature is above $0^{\circ} \mathrm{C}$ (THAWF; Table 3: Eq. 3). Soil temperature and peak root biomass affect potential root growth similarly to the effect of temperature and peak leaf biomass on leaf growth. Potential root growth is also affected by soil water and effective nutrient uptake ability (Table 3: Eq. 4). Root growth increases as soil water content approaches $98 \%$ of field capacity, but higher water contents greatly inhibit root growth (WATERF; Table 3: Eq. 5a-d). Root growth varies in the soil horizons according to nitrogen uptake ability. Roots with lower nitrogen uptake per unit length have priority for growth over those with higher nitrogen uptake (RTNTF; Table 3: Eq. 6), because greater root length is required to satisfy nitrogen demands.
Potential growth rates for each biomass compartment are altered by growth priority (LFALLOCATION, STALLOCATION, RTALLOCATION), where nitrogen limitation gives priority to root growth (Table 3: Eqs. 7-11).

Actual leaf, stem, and root growth (Table 3: Eqs. 1214) are calculated after considering total potential growth demands for carbohydrate, nitrogen, and phosphorus (Table 3: Eqs. 5-7). If the demands for each are less than the amounts available (Table 3: Eqs. 1719), growth proceeds at an unmodified potential rate. If the demands are greater than the reserves, the growth rates are modified (Table 3: Eq. 20) according to the most limiting resource, and new growth demands are calculated. The method of assigning priorities to growth of leaves, stems, and roots by supply and demand follows Morgan (1976). In the present ARTUS model, shoot population dynamics are not considered.

Death of vascular plants and fate of standing dead.In the model, leaf death is controlled by nitrogen con- 


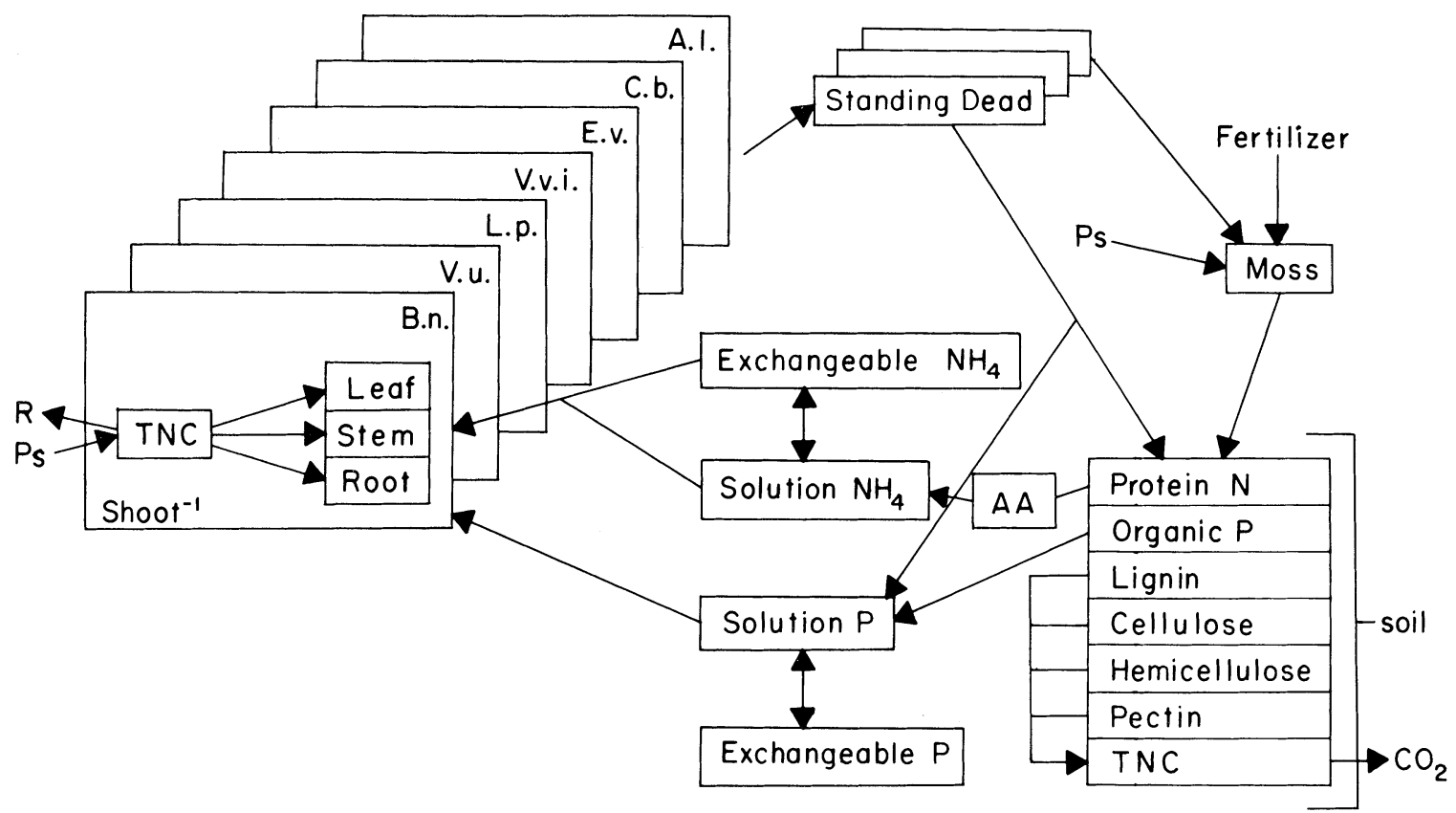

FIG. 3. Relational diagram of state variables (rectangles) and major flows of carbon and nutrients in the tussock tundra simulation model. The species included are Betula nana (B.n.), Vaccinium uliginosum(V.u.), Ledum palustre (L.p.), Vaccinium vitis-idaea (V.v.i.), Eriophorum vaginatum (E.v.), Carex bigelowii (C.b.), and Arctagrostis latifolia (A.l.).

tent and air temperature (Table 3; Eqs. 21 and 22); leaf turnover rates are an additional factor controlling leaf death in graminoids (Table 3: Eq. 23). Daily leaf death is the sum of the death rate due to the three causes (Table 3: Eq. 24). Leaf death due to nitrogen deficiency occurs when the fraction of nitrogen in the leaf is below a species-specific level (LFNDETH). The farther the air temperature falls below a certain value, the greater is the leaf death. For graminoids, daily leaf death due to leaf turnover (TURNDETH) depends on the average life span of a leaf (Murray and Miller 1982). Evergreen shrubs have a small leaf turnover after mid-July. Dead leaves of shrubs are added to the top organic soil layer, while dead leaves of graminoids are added to the standing dead compartment where they have a mean longevity of $4 \mathrm{yr}$ under ambient conditions. In the simulated off-road vehicle perturbation, the standing dead is crushed to the moss surface. Dead roots, which die annually during freeze-up in the fall, are added to the organic matter of the soil layer in which they occurred.

Photosynthesis and respiration. - Reported values of photosynthetic maxima for arctic species vary considerably, because of differences in growth temperature, ecotype, and site (Billings et al. 1971, Smith and Hadley 1974, Hinklenton and Oechel 1977, Bigger and Oechel 1982). Photosynthetic rates (as $\mathrm{CO}_{2}$ evolved) of $B$. nana, for example, range from $11 \mathrm{mg} \cdot \mathrm{g}^{-1} \cdot \mathrm{h}^{-1}$ (Shvetsova and Voznesensky 1970) to $37 \mathrm{mg} \cdot \mathrm{g}^{-1} \cdot \mathrm{h}^{-1}$ (Johnson and Tieszen 1976). Smith and Hadley (1974) calculated an $80 \%$ elevation in maximal photosyn- thetic rate in Ledum plaustre ssp. groenlandicum following a $15^{\circ} \mathrm{C}$ elevation in growth temperatures. Maximum photosynthesis under constant conditions also varied by over $30 \%$ among plants from different locations. Annual photosynthetic rates acclimated by up to $58 \%$, and populations varied by up to $48 \%$ in photosynthetic rates under constant temperatures (Smith and Hadley 1974).

Photosynthesis is calculated from the maximum photosynthetic rate (PMAX), a temperature function, and a light function (Table 4: Eq. 1; Appendix 2: Table A2). The temperature function (TMPF) for photosynthesis differs by species (Table 4: Eq. 2a-f) and was derived from a regression of photosynthesis rate on temperature (Limbach et al. 1982). The maximum rate is further reduced by a solar factor (SOLARFACTOR) (Table 4). The solar factor increases linearly from the daily compensation point to a daily maximum radiation level, considered here to be $25.9 \mathrm{MJ} \cdot \mathrm{m}^{-2} \cdot \mathrm{d}^{-1}$. The solar factor was derived from the generally linear patterns of daily photosynthetic rate vs. daily radiation found by Tieszen (1978) and from data from instantaneous cuvette studies (Limbach et al. 1982). The solar factor is multiplied by the canopy leaf mass per growing point to give the canopy photosynthetic rate, and by 0.00068 to convert from milligrams of carbon dioxide to grams of carbohydrate. Betula nana leaves are calculated to receive full solar radiation (SOLAR) (Table 4). For the other species, the average radiation incident on leaves is calculated as one-half of the sum 
TABLE 3. Equations used to calculate vascular plant growth and leaf death. See Appendix 1 for definitions of variable names.

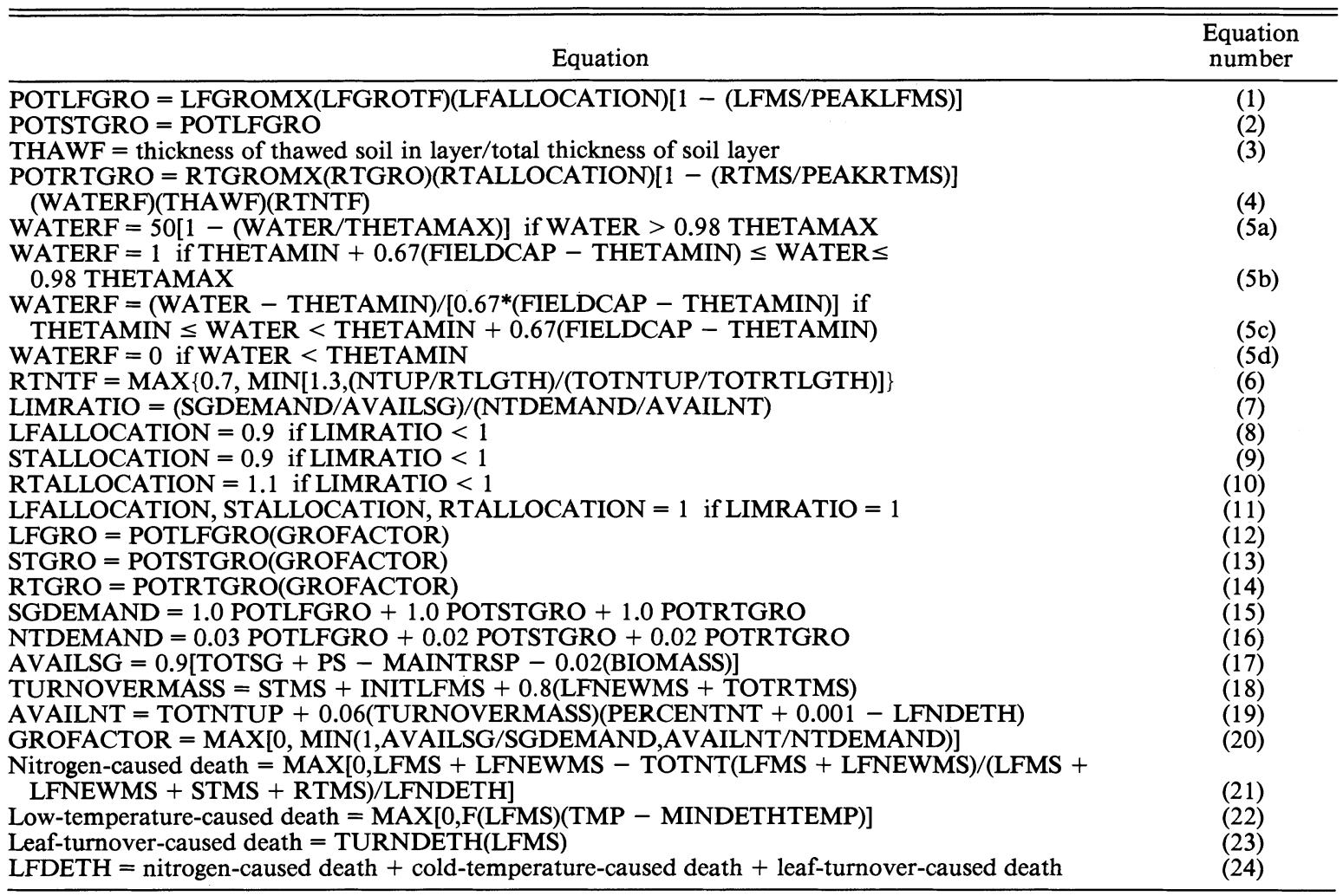

of the solar at the top of the canopy and at the bottom of the canopy (Table 4: Eq. 5b). To simplify calculations of photosynthetic rates below light compensation, an amount of carbon dioxide equivalent to dark respiration is added to the maximum photosynthetic rate (Table 4: Eq. 1). The same amount of carbon is subtracted from the resultant photosynthate pool. Carbon dioxide assimilation is converted to a sugar equivalent for the calculation of carbon budget of the plant.

Leaf respiration is calculated as the maximum value of either zero or the value resulting from an exponential temperature function (Table 4: Eq. 7) times the leaf mass (LFMS) (Limbach et al. 1982). Stem and root respiration are calculated as a temperature function (Table 4: Eq. 7) and are multiplied by the stem (STMS) and root mass (RTMS), respectively. For root respiration, calculations take into account the biomass and soil temperature of each soil horizon (Table 4: Eq. 8). Total plant respiration is the sum of leaf, stem, and root respiration (Table 4: Eq. 8). Respiration rates are converted to grams per $24 \mathrm{~h}$ and to a sugar equivalent basis.

\section{Mosses}

Data on total moss biomass were obtained from Shaver and Cutler (1979) and Miller et al. (1982) and were modified by the relative cover of the different species (Alpert and Oechel 1984). About 45\% of the cover in the Eagle Creek tussock tundra consists of three moss genera: Sphagnum, Dicranum, and Polytrichum. Sphagnum species make up almost $50 \%$ of the moss cover and dominate the intertussock areas. The other moss species are commonly found within the tussock itself. Polytrichum species are the only mosses that have functional stems, which can be in excess of $10 \mathrm{~cm}$ long and which extend into the organic soil layer. Bryophyte cover is accurately known for the Eagle Creek site but is less accurately known for the other research sites.

The green moss biomass in the tussock tundra at Eagle Creek was reported to be from $225 \mathrm{~g} / \mathrm{m}^{2}$ (Chapin et al. 1979) to $288 \mathrm{~g} / \mathrm{m}^{2}$ (Shaver and Cutler 1979), of which Sphagnum contributed $116 \mathrm{~g} / \mathrm{m}^{2}$ (Chapin et al. 1979). In ARTUS green biomass by species is assumed to be proportional to the relative cover of each species (Alpert and Oechel 1982) and is therefore calculated as $134 \mathrm{~g} / \mathrm{m}^{2}$ for $S$. capillaceum, $70 \mathrm{~g} / \mathrm{m}^{2}$ for D. elongatum, $47 \mathrm{~g} / \mathrm{m}^{2}$ for $P$. commune, and $37 \mathrm{~g} / \mathrm{m}^{2}$ for other moss and liverwort species (Alpert and Oechel 1984).

With the exception of $P$. commune, the mosses included in ARTUS grow above the top soil horizon. The total nonstructural carbohydrate pool (TNC) for mosses during the early season at Eagle Creek was assumed to be the same as that measured at Schefferville, 
TABLE 4. Equations used to calculate vascular plant photosynthesis and respiration. See Appendix 1 for definitions of variable names.

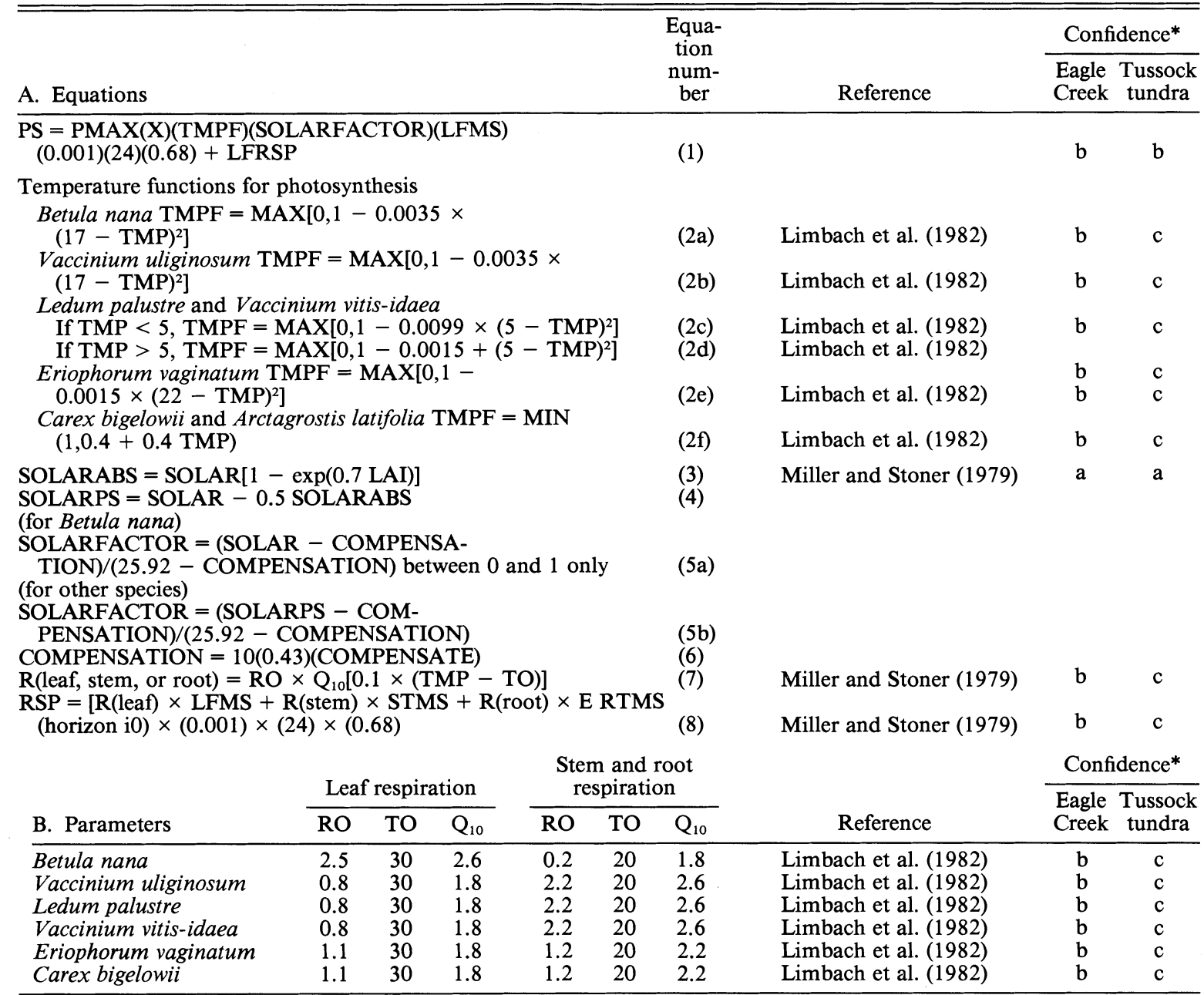

* Degree of confidence in the value as representing conditions at the indicated sites. Highest confidence is denoted as a, lowest as d. Rough numerical estimates of degree of confidence are indicated in Table 2.

Quebec, for Dicranum fuscescens (Hicklenton and Oechel 1977), and the same as measured at Atkasook in north-central Alaska for Aulocomnium and Polytrichum (F. S. Chapin and J. D. McKendrick, personal observation). Data used in ARTUS for nitrogen and phosphorus contents were from measurements in black spruce forest for Sphagnum subsecundum (Skre and Oechel 1979) and at Atkasook for Polytrichum (Chapin et al. 1980).

Moss photosynthesis is limited by incident light, temperature, and water content (Table 5: Eq. 1-6b; Appendix 2: Table A3). Moss growth rate is constrained by available carbohydrate, nitrogen, and phosphorus and by the maximum intrinsic rate of growth. The lower moss leaves are considered dead when they fall below the calculated light compensation level for photosynthesis. Outputs from moss processes affect nutrients available to vascular plants, organic matter available to decomposition, net primary productivity, and net ecosystem carbon dioxide flux.
The measured maximum photosynthetic rates (PMAX) for D. fuscescens and for Sphagnum subsecundum were similar (Oechel 1976) and were fivefold higher than the rates for $P$. commune (Skre and Oechel 1981). In ARTUS these rates are multiplied by $20 \mathrm{~h} / \mathrm{d}$ to convert to a daily rate, assuming an average daylight period of $20 \mathrm{~h}$. The solar irradiance incident on the moss (SOLARMOSS) is the incoming solar irradiance above the vascular plant canopy reduced by a function of leaf area index (LAI) (Table 5: Eq. 2). Because the radiation function for daily moss photosynthesis saturates at low daily irradiance and is an exponential function (Oechel and Sveinbjornsson 1978; Table 5: Eq. 3), photosynthesis reaches $95 \%$ of its potential maximum at $8.10 \mathrm{MJ} \cdot \mathrm{m}^{-2} \cdot \mathrm{d}^{-1}$, which is relatively low irradiance when compared to values for vascular plants (Tieszen 1978).

Moss photosynthesis is moderated by a temperature function (TMPF) (Table 5: Eq. 4a, b) that calculates a reduction in photosynthetic rates due to nonoptimal 
TABLE 5. Equations used to calculate the carbon and nutrient balance of mosses. See Appendix 1 for definitions of variable names. $\uparrow=$ raised to the power of.

\begin{tabular}{|c|c|}
\hline Equation & $\begin{array}{c}\text { Equation } \\
\text { number }\end{array}$ \\
\hline 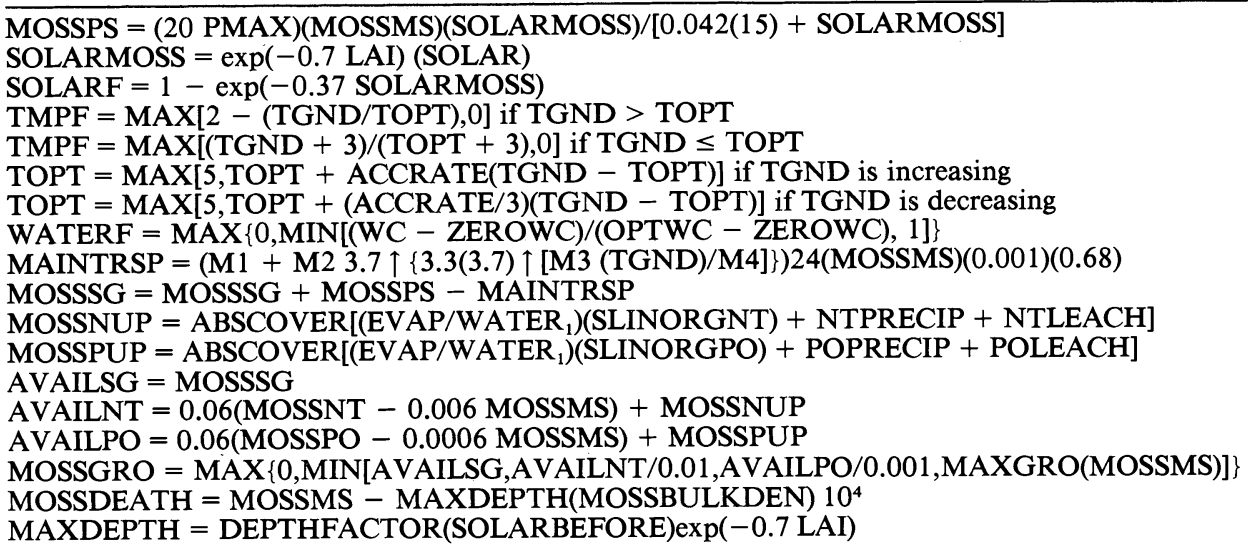 & $\begin{array}{l}(1) \\
(2) \\
(3) \\
(4 \mathrm{a}) \\
(4 \mathrm{~b}) \\
(5 \mathrm{a}) \\
(5 \mathrm{~b}) \\
(6) \\
(7) \\
(8) \\
(9) \\
(10) \\
(11) \\
(12) \\
(13) \\
(14) \\
(15) \\
(16)\end{array}$ \\
\hline
\end{tabular}

temperatures. The temperature optimum (TOPT) is calculated each day (Table 5: Eq. 5a, b), depends on the previous-days optimum, and approaches the mean ambient ground temperature (TGND) of the day at species-specific acclimation rates (ACCRATE) (Sveinbjornsson and Oechel 1983). Because mosses appear to acclimate more slowly to decreasing temperatures than to increasing temperatures (Oechel 1976, Hicklenton and Oechel 1977), the acclimation rate is reduced to one-third in the case of decreasing temperatures (Table 5: Eq. 5b).

With respect to moss water content (WC), photosynthesis is assumed to decrease linearly from a maximum at the optimal water content (OPTWC) to zero at the compensation point (ZEROWC) (Oechel and Collins 1976; Table 5: Eq. 6; Appendix 2: Table A4). Above the optimal water content, photosynthetic rate is assumed to be maximal, although some data indicate that photosynthesis may decrease at supraoptimal water contents (Oechel and Collins 1976). Water contents yielding optimal photosynthesis rates were seven times higher for $S$. subsecundum than for P. commune (Skre and Oechel 1981). In ARTUS D. elongatum and other mosses are assumed to have an optimal water content about twice that of $P$. commune. The water content at which positive photosynthesis is no longer maintained varies by species. This lower water content is usually correlated with the water-holding capacity of the species (Oechel and Sveinbjornsson 1978, Skre and Oechel 1981). Sphagnum subsecundum has the highest water compensation point; Polytrichum commune and $D$. elongatum have a compensation point about half that of S. subsecundum.

Finally, to simplify certain calculations for the determination of net ecosystem respiration, photosynthesis is augmented by a value equal to maintenance respiration. Moss maintenance respiration
(MAINTRSP) is calculated over $24 \mathrm{~h}$, is species specific, and depends on temperature (Table 5: Eq. 7). In the simulations, the pool of total nonstructural carbohydrate (MOSSSG) is augmented by photosynthesis and reduced by respiration and new growth (Table 5: Eq. 8).

Nitrogen and phosphorus taken up by the mosses (MOSSNUP and MOSSPUP) come from two major sources. One is the nitrogen and phosphorus in the soil solution that moves by mass flow to the moss surface to replace water that evaporates. This is calculated as the inorganic nitrogen (SLINORGN) or phosphorus (SLINORGP) in the soil solution times the fraction of water evaporated from the soil (EVAP/WATER). Other sources of nitrogen and phosphorus are from precipitation (NTPRECIP, POPRECIP) (G. M. Marion, personal observation) and throughfall precipitation which leaches nitrogen and phosphorus from vascular plants (NTLEACH, POLEACH). All sources are adjusted for the absolute cover (ABSCOVER) of the moss species (Table 5: Eqs. 9 and 10).

Moss growth is calculated as the minimum rate allowed by the following factors: maximum intrinsic rate of growth (MAXGRO), the sugar reserves (AVAILSG), and the nitrogen and phosphorus reserves (AVAILNT, AVAILPO) (Table 5: Eqs. 11-14). One gram dry mass of new growth requires $1 \mathrm{~g}$ sugar, $0.01 \mathrm{~g} \mathrm{~N}$, and 0.001 g P. Sugar available for growth is from reserves that remain after photosynthesis and maintenance respiration. Available nitrogen is all nitrogen uptake plus $6 \%$ of the tissue nitrogen in excess of $0.006 \mathrm{~g} / \mathrm{g}$ moss. This $6 \%$ represents nitrogen made available through protein turnover. Moss tissue dies (MOSSDEATH) at depths below the light compensation point for photosynthesis (Table 5: Eq. 15); depths are expressed as biomass or depth times bulk density. The maximum depth (MAXDEPTH) on a given day is set by the 


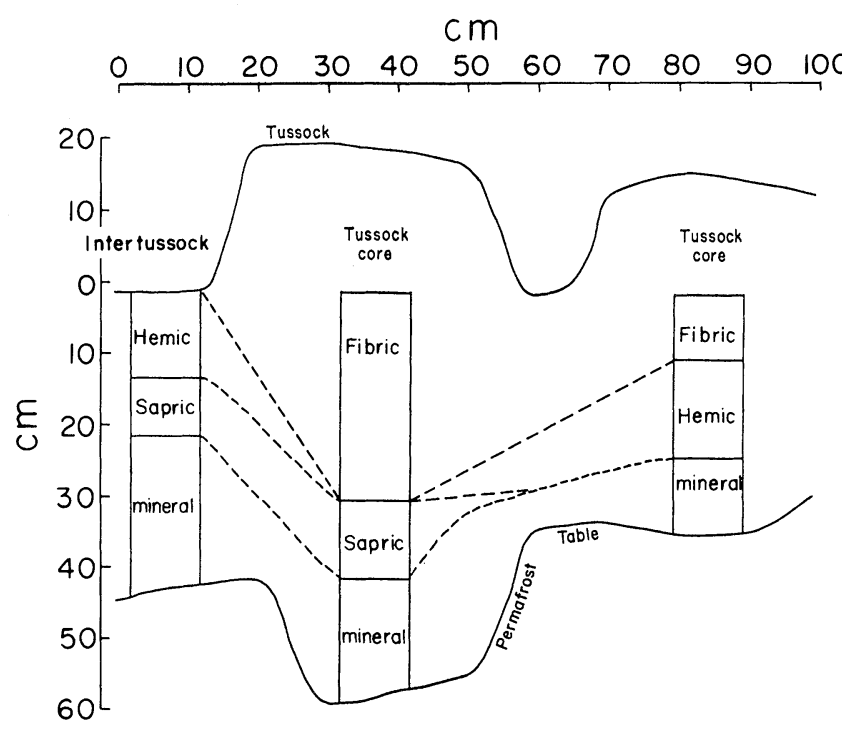

Fig. 4. Cross section of typical tussock tundra soil at Eagle Creek, Alaska. Dashed lines indicate suggested horizon correlations.

species-specific attenuation of light through the moss canopy (DEPTHFACTOR) and by solar irradiance. In order to smooth the moss biomass curve from day to day, the solar irradiance used is the amount available before atenuation by daily climate (SOLARBEFORE) (Table 5: Eq. 16). At the end of the simulation year, dead moss is added as organic matter to the top soil horizon.

\section{Soil processes and nutrient cycling}

Soil properties. - Generally, tussock tundra soils have four recognizable horizons of functional importance (Fig. 4). Three of these are primarily organic and one is primarily mineral. At the base of the green vegetation is the fibric horizon, which consists of low-density, relatively undecomposed remains of leaves, stems, and roots; this horizon ranges in thickness from $<5$ to 30 $\mathrm{cm}$ or more. Beneath the fibric horizon is the hemic horizon, which contains organic material in a more advanced state of mechanical and biochemical decomposition because of its greater age and the mass of the overburden. This horizon is not always present; if present it is $12-20 \mathrm{~cm}$ thick. Below the hemic horizon is a dark-colored organic horizon, 6->20 cm thick, termed sapric, which consists of highly decomposed materials. At Eagle Creek the fibric, hemic, and sapric horizons measured beneath tussocks were $9.0 \pm 0.4,14.4 \pm 0.6$, and $12.4 \pm 0.7 \mathrm{~cm}$ thick, respectively (Marion and Miller 1982). The three organic horizons differ substantially in chemical and physical properties (Appendix 2: Table A5). These horizons in various combinations constitute the primary histic or organic component of the soil and are the medium in which most vascular plants are rooted.
Below the organic horizons is mineral material into which only a few plant species extend their roots. The mineral horizon extends to an indeterminate depth with the upper 10-40 cm undergoing seasonal thaw and thus being a part of the active layer. The mineral horizon commonly contains some sapric organic material.

The sequential ordering of organic horizons in tussock tundra shows considerable spatial variability (Fig. 4). Generally, intertussock areas lack the fibric horizon. In other tussock tundra areas, frost scars are important and may constitute from 10 to $30 \%$ of the tundra. In frost scars mineral material is exposed at the surface. To encompass the natural variability, a wide range of physical and chemical-biochemical characteristics are used as initial conditions in ARTUS (Appendix 2: Table A5).

The average depth of the active layer, or total seasonal thaw value, may vary from year to year by $10 \%$ depending upon onset of thaw, soil moisture content of thawed horizons, and accumulated positive degree days. The thickness of the active layer on any given day represents the available rooting volume and potential organic matter reservoir for decomposition or mineralization.

As formulated in ARTUS, bulk density (BD) increases with depth (Appendix 2: Table A5), because of the combined effects of compression from overlying horizons, physical commutation, and biochemical oxidation. The increased bulk density increases thermal conductivity, decreases porosity, and usually decreases permeability and hydraulic conductivity (Allan et al. 1969, Everett 1973, Chapin et al. 1979). However, these thermal and moisture parameters were not included in ARTUS. Commensurate with increasing bulk density is an increase in the proportion of biochemical 
compounds resistant to decomposition and a decrease in the potential nutrient release. Commonly, the organic horizons with highest bulk densities lie deepest in the active layer where soil temperatures are $1^{\circ}-2^{\circ}$ and microbial activities are low. Such horizons, especially the sapric, may constitute $30 \%$ of the soil volume and often overlie mineral horizons with a sharp physical discontinuity. At the end of the 1979 summer season the thawed mineral horizon measured at Eagle Creek constituted $35 \%$ of the active layer under tussocks and 49\% under intertussock areas (Marion and Miller 1982). The mineral horizons have relatively high bulk densities and low hydraulic conductivities. Field observations indicate that movement of the soil solution occurs in the upper 10-20 cm of the soil column and primarily at the junction of the surface fibric horizon and the underlying hemic or sapric horizon. However, in ARTUS the depth at which water drains from the soil is not explicitly calculated.

During winter the surface soil may be supersaturated, with ice volumes exceeding the thawed pore volume, but much of the profile may be unsaturated until the spring thaw releases meltwater that can penetrate into the soil. The active layer of tussock tundra becomes saturated, i.e., the pore volume becomes filled with water, early in the growing season. In most years tussocks probably become unsaturated as the growing season progresses. The upper $25-40 \mathrm{~cm}$ of the soil column are unsaturated for variable lengths of time during late July to mid-August, as indicated by the precipitation of iron manganese humates in the deeper levels (K. R. Everett, personal observation).

The soil solution is the transport medium for nutrients moving between the organic and/or mineral exchange complex and the plant roots. The more advanced the decomposition state of the organic matter, the more effective it is as an exchange complex. In sapric materials the cation exchange capacity (concentration of exchangeable charges) reaches $300 \mathrm{mmol} /$ $100 \mathrm{~g}$ (Chapin et al. 1979).

The organic carbon content, calculated as 0.58 times the dry mass of organic matter, may decrease somewhat as the decomposition state advances. This relationship is often variable. When bulk density was considered, the concentration of organic $\mathrm{C}$ in fibric horizons of Eagle Creek soils was $\approx 5.7 \mathrm{~kg} / \mathrm{m}^{2}$, in hemic horizons $6.3 \mathrm{~kg} / \mathrm{m}^{2}$, and in sapric horizons $6.5 \mathrm{~kg} / \mathrm{m}^{2}$. Organic carbon in mineral horizons ranged from $<1$ to as much as $8 \mathrm{~kg} / \mathrm{m}^{2}$, depending upon the amount of enmixed organic material (Chapin et al. 1979).

Recognized differences in decomposition state among the three organic horizons also reflect measurable differences in the quality or availability of those horizons as substrates for microbial decomposition. As decomposition increases, total percent nitrogen increases (Appendix 2: Table A6) as do lignin and other complex polyphenolic compounds; cellulose and hemicellulose decrease. Total nonstructural carbohydrate in the soil compartment also decreases relative to the amount found in living plant material and then remains essentially unchanged. Soil $\mathrm{pH}$ influences several soil and plant processes including phosphorus availability, but these effects of soil $\mathrm{pH}$ were not included in ARTUS.

Decomposition. - In ARTUS decomposition of selected carbon compounds in the soil is based on an understanding of extracellular soil enzyme activity (McLaren 1975, Burns 1978, Linkins et al. 1978, Spaulding 1978, Linkins and Neal 1982, S. A. Herbein et al., personal communication). An analysis of enzymatic activity is used to simulate a basic rate of decomposition that is modulated by soil temperature and moisture. Soil pH was not used in ARTUS because cellulases and phosphatases were relatively insensitive to changes of $\pm 2.5 \mathrm{pH}$ units about the mean soil $\mathrm{pH}$ (Linkins 1981, Herbein 1981). Enzymatic decomposition is included for the following compounds: (1) structural plant polysaccharides (cellulose, hemicellulose, and pectin); (2) organic nitrogen (protein, polypeptides, and chitin); and (3) organic phosphomonoesters (inositol phosphates, nucleotides, glycerophosphates, and sugar phosphates).

The decomposition of plant structural polysaccharides was modeled after the well-studied extracellular multienzyme complex cellulase, which hydrolyzes cellulose to glucose (Reese 1977, Eriksson 1978). The two general functional components of the cellulase complex are endocellulase and exocellulase. Endocellulase initiates cellulose hydrolysis into soluble oligosaccharides, while exocellulases release products assimilated by microorganisms. Cellulase activity was also used to describe the general nature and rate of hydrolysis of other plant structural polymers because of close correlations between cellulase and xylanase activities and respiration in conifer litter (Spaulding 1978) and between hydrolytic activity of purified cellulases and polyxylan and galactan substrates (Hedges and Wolfe 1974, Kanda et al. 1976, Reese 1977). In ARTUS lignified structural polymers were assumed not to decompose.

The temperature response for cellulose hydrolysis between $0^{\circ}$ and $14^{\circ}$ was derived from endocellulase activity since endocellulase activity has been shown to be the limiting component in overall cellulose hydrolysis at these temperatures (Linkins 1981, Linkins et al. 1983). Enzymes are assumed to be inactive below $0^{\circ}$. The cellulose hydrolysis-temperature relationship is used in the hydrolysis of all other plant structural polysaccharides and protein.

The best correlations between temperature and moisture and cellulose hydrolysis occur when the ratio of exo- and endocellulase is used in ARTUS. This ratio represents a better expression of enzyme activity related to the generation of products for microbial assimilation than does the use of a single enzyme. Furthermore, expression of enzymatic activity as a ratio 
TABLE 6. Equations used to calculate nitrogen cycling in the enzyme model. See Appendix 1 for definitions of variable names. For soil outputs and updates, see Table 17.

\begin{tabular}{|c|c|}
\hline Equation & $\begin{array}{c}\text { Equation } \\
\text { number }\end{array}$ \\
\hline \multicolumn{2}{|l|}{ Soil input } \\
\hline $\begin{array}{l}\text { NTPRECIP }=0.001(\text { NTCONC)PRECIP } \\
\text { NTLEACH }=0.13 \text { (STANDDEADNT) }\end{array}$ & $\begin{array}{l}(1) \\
(2)\end{array}$ \\
\hline \multicolumn{2}{|l|}{ Mineralization } \\
\hline $\begin{array}{l}\text { TMPF }=\text { MAX }\{0, M I N[1,0.25+0.75(T S O I L / 20)]\} \\
\text { WATERF }=\text { MIN }\{1, \text { MAX }[0,1-(\text { WATER }-0.25) /(\text { THMAX }-0.25)]\} \\
\text { TMPFP }=\text { TMPF } \\
\text { WATERFP = WATERF } \\
\text { DKOPO4 = MIN[ORGANICP,(TMPF)(THAWF)(WATERF)(ORGANIC)(0.00094)] } \\
\text { THAWF }=\text { THAWTHICK/THICK } \\
\text { DKLIGN }=0 \\
\text { DKCELL }=\text { MIN[CELL,(TMPF)(THAWF)(WATERF)(ORGANIC)(0.00096)] } \\
\text { DKHEMI = MIN[HEMI,(TMPF)(THAWF)(WATERF)(ORGANIC)(0.00096)] } \\
\text { DKPECT }=\text { MIN[PECT,(TMPF)(THAWF)(WATERF)(ORGANIC)(0.0000144)] } \\
\text { DKPROT = MIN[PROT,(TMPF)(THAWF)(WATERF)(ORGANIC)(0.00096)] } \\
\text { DKCHIT = MIN[CHIT,(TMPF)(THAWF)(WATERF)(ORGANIC)(0.00096)] } \\
\text { DKTNC }=\text { SOILTNC(0.05) } \\
\text { NTMIN = DKPROT } /(6.25 / 2) \\
\text { DECOMP = DKLIGN + DKCELL + DKHEMI + DKPROT + DKPECT + DKCHIT + DKTNC }\end{array}$ & $\begin{array}{l}(3) \\
(4) \\
(5) \\
(6) \\
(7) \\
(8) \\
(9) \\
(10) \\
(11) \\
(12) \\
(13) \\
(14) \\
(15) \\
(16) \\
(17)\end{array}$ \\
\hline
\end{tabular}

resolves problems of relating zero-order kinetic expressions of activity to complex natural systems (Linkins et al. 1978, 1983, Sinsabaugh et al. 1981).

Protein hydrolysis was characterized from the solubilization of an azo-dye coupled protein substrate (Rinderknecht et al. 1968). These assay end products represent soluble amino acid and polypeptic residues that are potentially available for direct microbial assimilation. This nitrogen is also available to the plant either through mycorrhizal association or from microbial death and the subsequent release of inorganic nitrogen. The model assumes no net annual immobilization of nutrients by microbes. Chitin hydrolysis was measured through an exochitinase assay from the solubilization of n-acetylglucosamine residues from chitin (Waterhouse et al. 1961).

Organic phosphorus mineralization was characterized from phosphomonoesterase activity, as determined from PNP-phosphate hydrolysis (Tabatabai and Bremner 1969) as modified by Herbein (1981). Organic phosphomonoesters were assumed to comprise up to $60-75 \%$ of the total organic phosphorus as has been estimated in some nontundra soils (Halsted and McKercher 1975).

All measurements of enzyme activity were made on soil samples from the hemic horizon. In ARTUS it is assumed that activity in the hemic samples is similar to that throughout the $30-\mathrm{cm}$ active layer of the soil and that modulation of enzyme activity by temperature and moisture is constant throughout the active layer. Decomposition is also assumed to become active and responsive to soil temperature and moisture during thaw, which occurs in $1-\mathrm{cm}$ intervals. Therefore the simulations with ARTUS represent decomposition as it would occur in a thawing, uniform, 30-cm hemic horizon. Parameter values were obtained from tussock tundra soils at Eagle Creek, Toolik Lake, and Cape Thompson, Alaska (Appendix 2: Table A6).

Enzymatic decomposition of cellulose, hemicellulose, protein, pectin, chitin, soil total nonstructural carbohydrate, and organic phosphomonoesters in organic matter is included in ARTUS. The initial amount of each compound present is a fraction of the organic matter present in a gram of soil. The initial state variable is updated daily by subtracting the amount of each compound that is decomposed during the previous day (Table 6). The total amount of soil organic matter decomposed by the soil enzymes is updated at the end of each simulated year.

The amount of each compound decomposed during the day is never more than the amount present in a gram of soil and is affected by the temperature of the soil (TEMPF) and the amount of water present (WATERF) (Table 6: Eqs. 3 and 4). Decomposition increases with increasing temperatures and approaches zero as the soil approaches a maximum soil-waterholding capacity. Soil temperature and soil water have different effects on the decomposition of organic phosphomonoesters (Table 6: Eqs. 5-7). Since it is assumed that enzymes are active only above $0^{\circ}$, decomposition only occurs in the thawed layer of the soil (Table 6: Eq. 8).

Lignin decomposition is set at 0 because the rate of lignin decomposition in arctic ecosystems is assumed to be so slow that it can be ignored over the 5-yr time frame used in these simulations (Table 6: Eq. 9). Nitrogen mineralized (NTMIN) is $6.25 \%$ of decomposed protein (Table 6: Eq. 16). Part of the nitrogen from decomposed protein is immediately immobilized by microorganisms and is not available for plant uptake. 
TABLE 7. Equations used to calculate nitrogen cycling in the soil incubation model. See Appendix 1 for definitions of variable names.

\begin{tabular}{|c|c|}
\hline Equation & $\begin{array}{l}\text { Equation } \\
\text { number }\end{array}$ \\
\hline \multicolumn{2}{|l|}{ Soil inputs } \\
\hline $\begin{array}{l}\text { NTPRECIP }=0.001(\mathrm{NTCONC}) \text { PRECIP } \\
\text { NTLEACH }=0.13(\text { STANDDEADNT) }\end{array}$ & $\begin{array}{l}(1) \\
(2)\end{array}$ \\
\hline \multicolumn{2}{|l|}{ Mineralization } \\
\hline $\begin{array}{l}\text { NO }=A(\text { SOILNT }) \\
N=(35-\text { TSOIL }) / 10 \\
\text { Log(NO }- \text { NOPT })=\log \text { NO }-\mathrm{K}(\text { time })^{\mathrm{B}} \\
\text { NFIELD }=\text { NOPT }(1 / 2.5)^{\mathrm{N}} \\
\text { NTMIN }=0.01(\text { NFIELD)(BD)(THAWTHICK) }\end{array}$ & $\begin{array}{l}(3) \\
(4) \\
(5) \\
(6) \\
(7)\end{array}$ \\
\hline \multicolumn{2}{|l|}{ Fertilizer } \\
\hline FERTADD $=0.20$ FERTN & (8) \\
\hline \multicolumn{2}{|l|}{ Internal equilibrium } \\
\hline $\begin{array}{l}\text { AVAILNT }=\text { SLINORGN + EXCHANGNT } \\
\text { EXCHANGNT = } 26 \text { AVAILNT } / 27 \\
\text { SLINORGN = AVAILNT } / 27 \\
\text { AVAILNT }=\text { SLINORGN + ECHANGNT + NTMIN + (NTLEACH + NTPRECIP })(1- \\
\text { ABSMOSSCOVER }+ \text { NTDRAIN, into layer, - NTDRAIN, out of layer, - PARTMOSSNTUP - } \\
\text { VASCNTUP }\end{array}$ & $\begin{array}{r}(9) \\
(10) \\
(11)\end{array}$ \\
\hline \multicolumn{2}{|l|}{ Soil output and update } \\
\hline $\begin{array}{l}\text { NTDRAIN = SLINORGNT(DRAIN)/WATER(THAWTHICK) + DRAIN } \\
\text { SYSTEMLOSS = NTDRAIN from lowest thawed layer }\end{array}$ & $\begin{array}{l}(13) \\
(14)\end{array}$ \\
\hline
\end{tabular}

This parameter can be varied easily to simulate nutrient additions. Mineralized nitrogen is taken up by the vascular plants and mosses (Table 7).

All of the soil total nonstructural carbohydrate is decomposed in the first $20 \mathrm{~d}$ after a soil horizon thaws. Soil carbohydrate is updated daily, and the level in the soil remains constant (Table 6: Eq. 15). Organic matter is incremented once a year through litterfall.

In ARTUS moisture effects are only considered in the range of $100-750 \%$ soil moisture as a percent of dry mass. Soil moisture values above $800 \%$ are not included because these values are assumed to indicate supersaturated soils with potential anaerobic conditions. However, apart from limiting lignin degradation (Hackett et al. 1977, Kirk et al. 1978), anaerobic conditions do not seem to affect directly the hydrolytic activities of the enzyme systems that were included in this study.

Nitrogen cycling. - The nitrogen-cycling submodel in ARTUS is one of two alternative models, the other being the enzymatic decomposition model, which are used to calculate nutrient release from dead organic matter. The nitrogen-cycling submodel considers nitrogen mineralization and uptake by plants and focuses on the available soil nitrogen pool. Nitrogen inputs to the available soil nitrogen pool include precipitation, throughfall, and mineralization (Table 7). Outputs of nitrogen from the available nitrogen pool include drainage losses and plant uptake. The dominant processes in the nitrogen cycle in most unperturbed tundra ecosystems are mineralization and plant uptake; inputs in precipitation and throughfall and outputs in drainage are generally minor components of the total nu- trient flux (Likens et al. 1977, Chapin et al. 1978, Van Cleve and Alexander 1981). Nitrification, dentrification, and ammonia volatilization are not considered in ARTUS because these processes are normally insignificant in tundra ecosystems (Van Cleve and Alexander 1981).

In ARTUS the input of nitrogen via precipitation is calculated using an average seasonal concentration of nitrogen in precipitation of $0.2 \mathrm{mg} / \mathrm{L}$ (Table 7: Eq. 1) (G. M. Marion, personal observation). Throughfall nitrogen addition is assumed to be $13 \%$ of the nitrogen content of leaf standing dead (Table 7: Eq. 2); the remainder of the nitrogen in standing dead material is added to the litter category. These proportions were based on the observation that throughfall nitrogen is $\approx 13 \pm 4 \%$ of the nitrogen in the litterfall in terrestrial ecosystems (Van Cleve and Alexander 1981).

Nitrogen mineralization is the key process making nitrogen available for plant growth in most terrestrial ecosystems. The submodel used to calculate nitrogen mineralization is based on the potential nitrogen mineralization concept developed by Stanford and Smith (1972) and adapted for prediction of tundra nitrogen mineralization by Marion amd Miller (1982) (Table 8 ). The potentially mineralizable nitrogen (NO) is redefined at the beginning of each year and serves as an upper bound on the mineralizable nitrogen within each soil horizon for that year. The regression equations used to predict mineralizable nitrogen from total soil nitrogen concentration were developed from Marion and Miller (1982). The temperature correction uses a $\mathrm{Q}_{10}$ of 2.5 (Marion and Miller 1982). A moisture correction is not included in the model because low soil 
TABLE 8. Parameter values used to calculate nitrogen mineralization for tussock and intertussock areas in Eriphorum vaginatum tussock tundra at Eagle Creek. Values were measured at $35^{\circ} \mathrm{C}$ and $20 \mathrm{kPa}$ soil moisture tension.* The mineralization equation is: $\log (\mathrm{NO}-\mathrm{NT})=\log \mathrm{NO}-\mathrm{K}(\mathrm{TIME})^{\mathrm{B}}$.

\begin{tabular}{|c|c|c|c|c|c|c|c|}
\hline $\begin{array}{c}\text { Soil } \\
\text { horizon }\end{array}$ & $\begin{array}{c}\text { Initial total } \\
\text { soil nitrogen } \\
\text { (SOILNT, \%) }\end{array}$ & $\begin{array}{c}\text { Fraction } \\
\text { potentially } \\
\text { mineralizable } \\
\text { nitrogen } \\
(\%)\end{array}$ & $\begin{array}{l}\text { Rate constant } \\
\left(\mathrm{K}, \mathrm{wk}^{-1}\right)\end{array}$ & $\begin{array}{l}\text { Time } \\
\text { exponent } \\
\text { (B) }\end{array}$ & $\begin{array}{l}\text { Coefficient of } \\
\text { determination } \\
\qquad\left(r^{2}\right)\end{array}$ & \multicolumn{2}{|c|}{ Confidence $\dagger$} \\
\hline Fibric & 0.45 & 2.44 & 0.1266 & 1.27 & 0.92 & a & 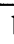 \\
\hline Hemic & 0.96 & 3.65 & 0.1114 & 1.07 & 0.98 & $\mathrm{a}$ & 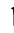 \\
\hline Sapric & 1.64 & 0.67 & 0.1352 & 0.90 & 0.98 & a & ( \\
\hline Mineral & 0.30 & 0.07 & 0.0265 & 0.20 & 0.95 & $\mathrm{a}$ & 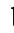 \\
\hline
\end{tabular}

* From Marion and Miller (1982), where soil moisture tension was measured in atmospheres $\left(1 \mathrm{~atm}=1.013250 \times 10^{5} \mathrm{~Pa}\right)$.

† See Table 2 for definitions of degrees of confidence.

moisture is probably not an important factor limiting nitrogen mineralization in these normally wet soils.

The nitrogen mineralization model is based on net nitrogen mineralization curves, i.e., mineralization in excess of microbial immobilization, which were developed from soil incubations (Marion and Miller 1982, Marion et al. 1982). Microbial incorporation of mineralized nitrogen is implicitly considered in the nitrogen mineralization submodel. The assumption is made that $80 \%$ of added nitrogen fertilizer (FERTN) is immobilized by microbes, which leaves $20 \%$ (FERTADD) for vascular species, mosses, and the exchange complex (Table 7: Eq. 8). This assumption was based on a nitrogen- 15 study in tussock tundra where $\approx 80 \%$ of the nitrogen fertilizer additions of $0,5,10$, and 15 $\mathrm{g} / \mathrm{m}^{2}$ was incorporated into the soil organic matter by microbes (Marion et al. 1981).

The upper bound on nitrogen uptake by plants (TOTNUP) from a given horizon is the available nitrogen pool (AVAILNT), which consists of soluble inorganic (SLINORGN) plus exchangeable nitrogen (EXCHANGT) (Table 7: Eqs. 9-14). Nitrogen uptake is assumed to be directly proportional to the effective root length of all species (TOTRTLGTH). The effective root length is the measured absorbing root length adjusted by the uptake adjustment factor, which is assumed to account for roots lost in excavations, for mycorrhizae, for variations in root mass in the soil relative to pockets of high nutrient availability and for variations in uptake efficiency in individual species. Mass : length ratios for roots were taken from Miller et al. (1982) and Chapin and Slack (1979). The root nitrogen uptake constant, $2.0 \times 10^{-5}$, was selected to give the correct seasonal total nitrogen uptake. Uptake for a given species (VASCNTUP) is apportioned by its effective root length (VASCRTLGTH) relative to total species absorbing root length (TOTRTLGTH).

Since nitrification is not significant in these soils (Van Cleve and Alexander 1981), inorganic nitrogen in ARTUS is wholly in the ammonium form. The equilibrium constant for soluble inorganic ammonium and exchangeable ammonium is derived from data collected at the wet coastal tundra at Barrow, Alaska (Ta- ble 7: Eqs. 10 and 11) (Gersper 1972, Flint and Gersper 1974). This ratio is only an approximation; the actual ratio depends on the specific ions associated with ammonium on the exchange complex and in solution. Movement of soluble nitrogen from horizon to horizon (NTDRAIN) and loss from the soil through deep drainage (SYSTEMLOSS) are included in ARTUS (Table 7: Eqs. 13 and 14).

Phosphorus cycling. - The phosphorus-cycling model in ARTUS describes the rate of phosphorus mineralization, the dynamics of phosphorus movement from dead plant material and precipitation into the soil, and subsequent phosphorus uptake by plants (Table 9; Appendix 2: Table A7). In ARTUS phosphorus enters tussock tundra systems only through precipitation (POPRECIP), because there is negligible chemical weathering of phosphorus (Table 9: Eq. 3; Ellis 1980). The model structure is similar to that described above for nitrogen except that uptake of phosphorus by vascular plants is calculated using parameters for plants and soil, whereas the nitrogen-cycling model uses only parameters for the soil.

Little is known about the mineralization of organic phosphorus. The rate and controls of phosphorus mineralization were assumed to be similar to those described above for nitrogen, and phosphorus mineralization rate in ARTUS is therefore calculated as $10 \%$ of that observed for nitrogen (Table 9: Eq. 1). These assumptions require verification.

The soil organic phosphorus pool (SOILPORG), which contains the bulk of phosphorus in tussock tundra, is augmented daily by inputs from death of moss, vascular plant roots, and leaves, and is depleted by mineralization (Table 9: Eqs. 2 and 4). In the uppermost soil horizon, which is $96 \%$ organic (Chapin et al. 1978), all phosphorus except soil solution and exchangeable phosphorus is assumed to be organic phosphorus. Soil organic phosphorus in lower soil horizons is calculated as nitrogen content times the nitrogen : phosphorus ratio of the uppermost soil horizon (Appendix 2: Table A7). A nitrogen : phosphorus ratio of 10 for both soil organic matter and vascular senescent leaves and roots is used in ARTUS (G. M. Marion 
TABLE 9. Equations used to calculate phosphorus cycling. See Appendix 1 for definitions of variable names.

\begin{tabular}{|c|c|}
\hline Equation & $\begin{array}{c}\text { Equation } \\
\text { number }\end{array}$ \\
\hline \multicolumn{2}{|l|}{ Phosphorus transformations } \\
\hline $\begin{array}{l}\text { SLINORGPO }=\text { SLINORGPO }+0.1 \times \text { NTMIN } \\
\text { SOILPORG }=\text { SOILPORG }-0.1 \times \mathrm{NTMIN}\end{array}$ & $\begin{array}{l}(1) \\
(2)\end{array}$ \\
\hline \multicolumn{2}{|l|}{ Phosphorus input to soil } \\
\hline $\begin{array}{l}\text { POPRECIP }=\text { POCONTENT } \times \text { PRECIP } \\
\text { SOILPORG }=\text { SOILPORG }+ \text { RTDETHPO + MOSSDETHPO }+(1-\text { POLEACH }) \times \text { DETHPO } \\
\text { SLINORGPO }=\text { SLINORGPO }+(1-\text { ABSCOVER }) \times \text { POPRECIP }+(\text { POLEACH } \times \text { DETHPO })\end{array}$ & $\begin{array}{l}(3) \\
(4) \\
(5)\end{array}$ \\
\hline $\begin{array}{l}\text { Phosphorus loss from soil } \\
\text { PODRAIN }=\text { SLINORGPO } \times \text { DRAINAGE/WATER }\end{array}$ & (6) \\
\hline \multicolumn{2}{|l|}{ Update of soil conditions } \\
\hline $\begin{array}{l}\text { If WATER }<\text { FIELDCAP } \\
\text { SLINORGPO }=0.1 \times(\text { SLINORGPO }+ \text { EXCHANGPO }) \\
\text { EXCHANGPO }=0.9 \times(\text { SLINORGPO + EXCHANGPO }) \\
\text { If WATER } \geq \text { FIELDCAP } \\
\text { SLINORGPO }=0.6 \times(\text { SLINORGPO + EXCHANGPO }) \\
\text { EXCHANGPO }=0.4 \times(\text { SLINORGPO + EXCHANGPO })\end{array}$ & $\begin{array}{r}(7) \\
(8) \\
(9) \\
(10) \\
(11) \\
(12)\end{array}$ \\
\hline \multicolumn{2}{|l|}{ Phosphorus uptake by plants } \\
\hline $\begin{array}{l}\text { MOSSPUP }=\text { ABSCOVER } \times(\text { POPRECIP }+ \text { POLEACH }+(\text { EVAP/WATER })+\text { SLINORGPO }) \\
\text { POUP }=\text { RTMS } \times \text { MYCO } \times \text { PUPCAP } \times \mathrm{X} \times \text { SLINORGPO } \\
\text { If WATER } \geq \text { FIELDCAP } \\
\mathrm{X}=1.0 \\
\text { If WATER }<\text { FIELDCAP } \\
\mathrm{X}=0.1 \times \text { WATER } \times \text { WATER }\end{array}$ & $\begin{array}{l}(13) \\
(14) \\
(15) \\
(16)\end{array}$ \\
\hline
\end{tabular}

and F. S. Chapin III, personal observation). Undissolved inorganic phosphorus is not included in the estimate of organic phosphorus. Thirteen percent of the senescent vascular leaf phosphorus (POLEACH) is considered to be inorganic and to be readily leached. In ARTUS the fraction of the leached phosphorus that falls on mosses is absorbed by them, and the remainder enters the soil inorganic-phosphorus pool. Phosphorus loss from the ecosystem occurs in the drainage of groundwater over the permafrost table. In ARTUS this loss is presumed to occur only from the inorganicphosphorus pool because the soluble organic phosphorus is a negligible proportion $(0.005 \%)$ of total organic phosphorus (Table 9: Eq. 6) (Barel and Barsdate 1978).

In the model soil solution inorganic phosphorus (SLINORGPO) is augmented by mineralization, leaching of standing dead material, and precipitation; and is reduced by phosphorus uptake by moss and vascular plants (Table 9: Eqs. 1, 5, and 6). Soil solution phosphorus measured at Eagle Creek (Appendix 2: Table A7) was 30-fold higher than that measured in wet tundra (Barel and Barsdate 1978). In ARTUS phosphorus in the soil solution is in equilibrium with a larger, exchangeable pool. At other sites under oxidizing conditions and low $\mathrm{pH}, 90 \%$ of this potentially available phosphorus was on the exchange complex rather than in the soil solution (Barel and Barsdate 1978). However, under anaerobic conditions, iron is converted to the ferrous form in some tussock tundras (Chapin and Shaver 1981), which probably makes inorganic phosphorus more available.
Phosphorus uptake in ARTUS is based on fundamentally different mechanisms in mosses, shrubs, and graminoids. Mosses absorb a fraction of the phosphorus leached from vascular plants, plus the phosphorus in precipitation, in proportion to their percentage cover (ABSCOVER) and by capillary movement of soil solution into mosses to replace water lost by evaporation (Table 9: Eq. 13). Shrubs are mycorrhizal, and graminoids are essentially nonmycorrhizal (Miller 1982). In ARTUS the daily absorption rate of mycorrhizal species equals the uptake capacity (PUPCAP) that was measured on excised roots (Chapin and Tryon 1982). The absorption rate is adjusted for phosphate concentration and a factor to account for increased effectiveness of phosphorus uptake by mycorrhizal roots in soil (Table 9: Eq. 14). The mycorrhizal adjustment factor was not measured directly but was calculated as a coefficient necessary to produce an annual phosphate accumulation in the model equal to the measured annual accumulation by each species. A similar uptake adjustment factor is used in the model for all deep-rooted shrubs that have access to available nutrients through the season as the depth of thaw increases (Appendix 2: Table A7). A large uptake adjustment factor is used for Vaccinium vitis-idaea, which is shallow rooted and only has access to nutrients in the upper soil layer. Mycorrhizae are largely absent from saturated anaerobic soils (A. E. Linkins, personal observation), so the uptake adjustment factor was 1.0 under such conditions. Calamagrostis canadensis and Poa arctica have recently been found to be endomycorrhizal at sites near Toolik Lake (A. E. Linkins, per- 
sonal observation). Therefore phosphorus uptake by these graminoids is calculated in ARTUS with a root uptake adjustment factor (Table 9: Eq. 14).

Phosphorus uptake by Eriophorum vaginatum is calculated without a root uptake adjustment factor because there is no evidence of extensive mycorrhizal association in this species (Miller 1982). In ARTUS the inorganic phosphorus concentration at the root surface of $E$. vaginatum is assumed to be reduced by diffusion limitation to $10 \%$ of that measured in the bulk soil solution in unsaturated soils. In saturated soils, phosphorus at the root surface is assumed to be replenished at a rate proportional to the square of the volumetric water content (F. S. Chapin, III and P. H. Nye, personal observation). Nye and Tinker (1977) found that high soil water contents increased the quantity of soil solution in the vicinity of the root and decreased the tortuosity, the diffusion distance, from the bulk soil to the root surface. When soil water content exceeds field capacity, water flows laterally and would also overcome the diffusion limitation of uptake. Thus, under saturated conditions it is assumed in ARTUS that root surface phosphate concentration equals that in the bulk root solution (Table 9: Eq. 15).

Daily temperature variations caused as much as 1 $\mathrm{cm}$ daily variation in thaw depth and caused refreezing and thawing of soil at a given depth several times per season (Barkley et al. 1978, Chapin et al. 1979). Cycles of freezing and thawing resulted in a release of exchangeable phosphorus into the soil-solution phosphorus pool (Saebo 1969). In ARTUS if the freezethaw interface occurs in a soil horizon, the inorganic phosphorus available to E. vaginatum roots is augmented by the amount available in the exchangeable pool in that horizon (Table 9: Eq. 16).

\section{Environmental driving variables,} heat exchange, and water balance

The abiotic section of ARTUS encodes the seasonal changes of the environmental driving variables and calculates the resultant thermal and water regimes to define the heat and water environments for the tussock tundra system. All parameter values are daily means or daily totals in concordance with the 1-d time step of ARTUS. The values for environmental variables are summarized data from Eagle Creek for 1978, 1979, and 1980 . The primary driving variables are daily total solar radiation, air temperature, precipitation, surface albedo, wind, and sky conditions (Appendix 2: Table A8). Empirical equations that fit the measurements are used to calculate the seasonal changes of environmental driving variables for the model (Table 10).

The seasonal course of potential maximum daily total solar radiation (SOLAR) and of potential maximum daily mean temperature (TMP) is calculated using a sinusoidal fluctuation about a seasonal mean value (Table 10: Eqs. 1 and 2, respectively). The magnitude of the seasonal fluctuations of solar radiation and temperature is governed by the amplitude parameters (SMAX-SMIN)/2 and TAMP, respectively. The timing of the peak value is governed by the day in the season, as determined from field data. These potential maxima are then reduced on a day-by-day basis, depending upon sky conditions and precipitation events. Heat sums (degree days, Table 10: Eqs. 3 and 4) are calculated for air temperature and surface temperature by accumulating the degree-day product for days when mean temperatures were above $0^{\circ}$. Tundra surface temperature (TGND) is calculated as a simple function of solar radiation (Table 10: Eq. 5). Surface temperature is then reduced according to daily evaporation and precipitation (Table 10: Eq. 2).

Longwave radiation from the tundra surface (IRUP) is calculated (Table 10: Eq. 6) as blackbody radiation dependent on the surface temperature. Net longwave radiation (IRNET) is calculated using a Brunt-type formulation (Table 10: Eq. 7) that utilizes air temperature, vapor pressure of the air, and an overcast index for the sky (Brunt 1932). Longwave radiation from the sky (IRSKY) is then calculated as the residual from the net and surface longwave radiation (Table 10: Eq. 8).

The probability of precipitation is based on measurements at the Eagle Creek site and is calculated each day as a random event with a probability of .23 . If precipitation occurs, its duration is a random variable of 1-6 d. The precipitation on each day is a uniform random variable between 0.5 and $10.5 \mathrm{~mm}$, based on measured data. On days with precipitation, solar radiation is reduced by a precipitation factor, relative humidity is set at $100 \%$, the sky is considered fully overcast, and air and surface temperatures are modified (Table 10: Eq. 10). Wind is also a stochastic variable varying uniformly between 96 and $216 \mathrm{~km} / \mathrm{d}$ (Table 10: Eq. 11).

Vapor pressure at any temperature is calculated (Table 10: Eq. 13) from relative humidity by the MagnusTetens method (Murray 1967). Potential evaporation from the tundra surface is derived (Table 10: Eq. 14) from the vapor pressure deficit of the air and net radiation above the tundra surface (Penman 1948). The actual evaporation is calculated (Table 10: Eq. 18) as the potential evaporation multiplied by the relative water content of the surface to allow water availability at the surface to affect the evaporation rate, based on Stuart et al. (1982).

Movement of water between soil horizons and drainage out of the soil column (Table 10: Eq. 19) is allowed only when water content is above the field capacity in the layer. Water is added to the lowest thawed horizon from the advancing thaw front (Table 10: Eq.20) according to the rate of thaw during the day. Substrate water content (WATER) is the bulk value for each soil horizon from the surface down to the thawing front. The moss water content is set equal to that of the top soil horizon. Soil water content is updated daily (Table 
TABLE 10. Equations used to calculate daily means or totals for environmental variables, water balance, and soil thaw. See Appendix 1 for definitions of variable names.

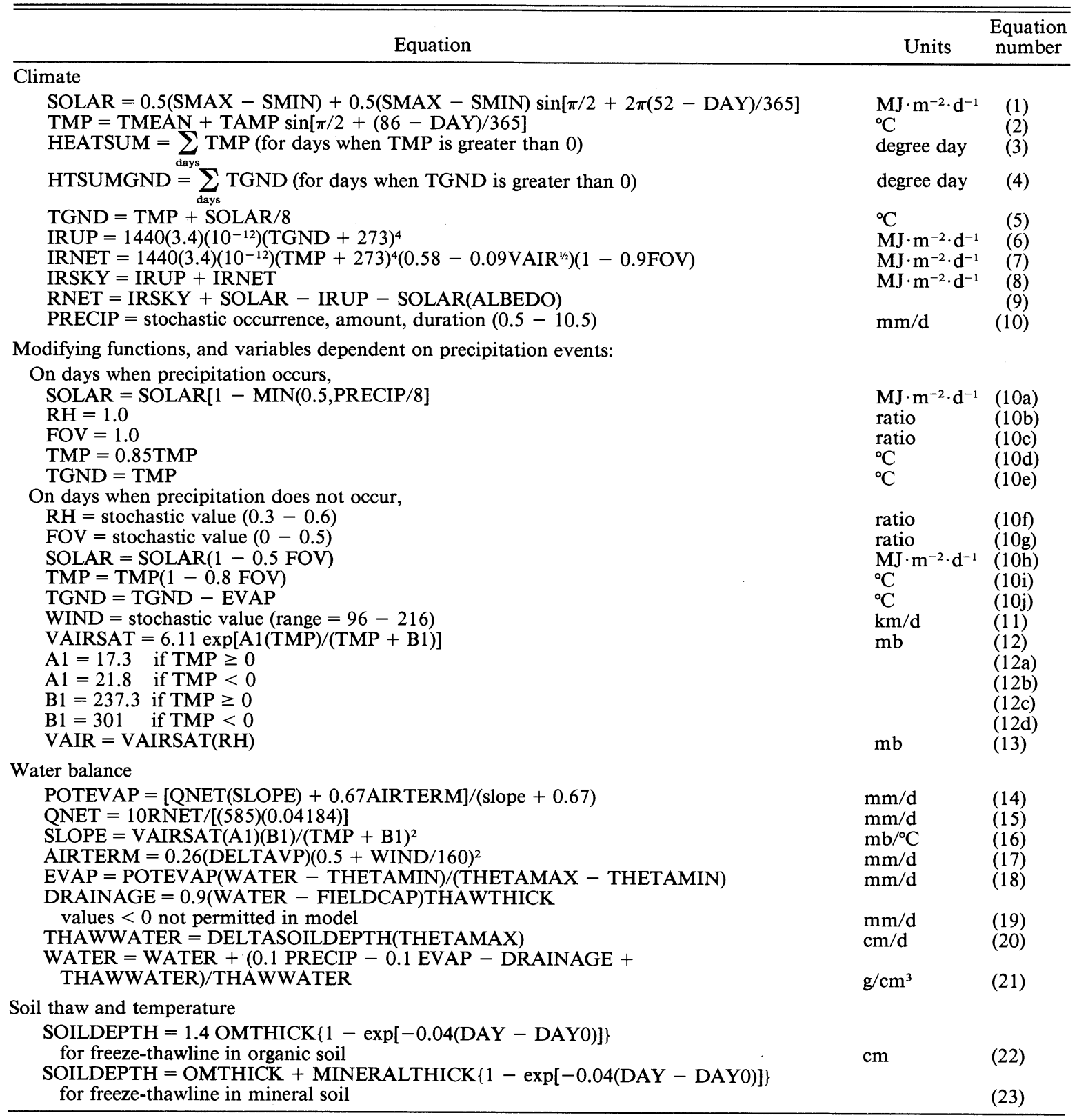

10: Eq. 21), considering additions from precipitation and thawing permafrost and losses by drainage and evaporation. The seasonal course of permafrost depth below the surface (Table 10: Eq. 23) is calculated as a smooth curve fitted to measurements of depth to permafrost as a function of the day of the season.

\section{Model Validation}

Several experiments and sets of observations were used for validating ARTUS. (1) Measurements were made under ambient conditions at Eagle Creek in years other than those used to generate parameter values for the model. (2) Tussock tundra was fertilized with nitrogen and phosphorus at Eagle Creek in 1970, 1975, 1976, and 1979 (Shaver and Chapin 1980) and at sites along the haul road in 1975 and 1976. (3) Measurements of leaf and shoot production, nutrient uptake, and ecosystem respiration were made under ambient conditions and in an off-road vehicle track at Eagle Creek in 1978 and 1979 (L. Stuart and P. C. Miller, personal observation, J. Kummerow and A. Jackson, personal observation). (4) Oil was spilled in experi- 
TABLE 11. Summary of values measured for validation with ambient conditions at Eagle Creek, the TAPS haul road sites, and Cape Thompson (means $\pm 1 \mathrm{SE}$ ). Summaries of simulated values with ambient conditions at each site are given in parentheses. $N=4$ for plant variables, 25 for thaw depth, 4-8 for ecosystem respiration. NP indicates species is not present; - indicates no data.

\begin{tabular}{|c|c|c|c|c|c|c|c|}
\hline \multirow[b]{2}{*}{ Variable } & \multirow[b]{2}{*}{ Eagle Creek } & \multirow[b]{2}{*}{ Old Man } & \multirow[b]{2}{*}{ Timberline } & \multirow[b]{2}{*}{ Toolik Lake } & \multirow[b]{2}{*}{ Sagwon } & \multicolumn{2}{|c|}{ Cape Thompson } \\
\hline & & & & & & East & West \\
\hline Thaw depth $(\mathrm{cm})$ & $62 \pm 1(75)$ & $43 \pm 1(99)$ & $-(105)$ & $44 \pm 2(55)$ & $47 \pm 1(56)$ & $60 \pm 1(106)$ & $57 \pm 1(106)$ \\
\hline $\begin{array}{l}\text { Ecosystem respiration }\left(\mathrm{CO}_{2} \text { release }\right) \\
\left(\mathrm{g} \cdot \mathrm{m}^{-2} \cdot \mathrm{d}^{-1}\right)\end{array}$ & $\begin{array}{c}2-3.8 \\
(1.4-2.7)\end{array}$ & $\begin{array}{l}2.1 \pm 0.4 \\
(1.5)\end{array}$ & $\begin{array}{l}1.6 \pm 0.2 \\
\quad(1.1)\end{array}$ & $\begin{array}{l}2.5 \pm 0.3 \\
\quad(1.8)\end{array}$ & $\begin{array}{l}1.2 \\
(0.85)\end{array}$ & - & - \\
\hline $\begin{array}{l}\text { Total vascular-plant dry-mass production, new leaf, } \\
\text { and new stem }\left(\mathrm{g} \cdot \mathrm{m}^{-2} \cdot \mathrm{yr}^{-1}\right)\end{array}$ & $\begin{array}{l}128 \\
(99)\end{array}$ & $\begin{array}{c}79 \\
(88)\end{array}$ & $\begin{array}{l}109 \\
(70)\end{array}$ & $\begin{array}{c}74 \\
(34)\end{array}$ & $\begin{array}{c}45 \\
(28)\end{array}$ & $\begin{array}{c}- \\
(70)\end{array}$ & $\begin{array}{c}83 \\
(43)\end{array}$ \\
\hline $\begin{array}{l}\text { Absorbing-root extension } \\
\left(\mathrm{km} / \mathrm{m}^{2}\right)\end{array}$ & $\begin{array}{l}11.1 \\
(1)\end{array}$ & $\overline{(1.3)}$ & - & $(0.6)$ & - & $(0.4)$ & - \\
\hline \multicolumn{8}{|l|}{ Shoot, new leaf, and stem dry mass production (mg/shoot) } \\
\hline Betula nana & $\begin{array}{c}34 \pm 6 \\
(21)\end{array}$ & $\begin{array}{c}81 \pm 9 \\
(23)\end{array}$ & $\begin{array}{c}70 \pm 8 \\
(15)\end{array}$ & $\begin{array}{c}32 \pm 6 \\
(15)\end{array}$ & $\begin{array}{l}45 \pm 4 \\
(14)\end{array}$ & $\begin{array}{c}65 \pm 5 \\
\quad(16)\end{array}$ & $\begin{array}{l}41 \pm 1 \\
(17)\end{array}$ \\
\hline Vaccinium uliginosum & $\begin{array}{c}26 \pm 2 \\
(20)\end{array}$ & $\begin{array}{c}37 \pm 4 \\
(21)\end{array}$ & $\begin{array}{r}23 \pm 1 \\
(15)\end{array}$ & $\begin{array}{l}9 \pm 2 \\
(14)\end{array}$ & $\begin{array}{l}\text { NP } \\
(13)\end{array}$ & $\begin{array}{l}\text { NP } \\
(12)\end{array}$ & $\begin{array}{l}\text { NP } \\
(14)\end{array}$ \\
\hline Ledum palustre & $\begin{array}{c}47 \pm 5 \\
(13)\end{array}$ & $\begin{array}{c}33 \pm 3 \\
(15)\end{array}$ & $\begin{array}{r}35 \pm 5 \\
(18)\end{array}$ & $\begin{array}{c}24 \pm 1 \\
(6)\end{array}$ & $\begin{array}{c}20 \pm 3 \\
(7)\end{array}$ & $\begin{array}{c}33 \pm 6 \\
(4)\end{array}$ & $\begin{array}{c}16 \pm 2 \\
(6)\end{array}$ \\
\hline Vaccinium vitis-idaea & $\begin{array}{c}40 \pm 3 \\
(13)\end{array}$ & $\begin{array}{c}22 \pm 3 \\
(16)\end{array}$ & $\begin{array}{c}27 \pm 2 \\
(18)\end{array}$ & $16 \pm 1$ & $\begin{array}{c}15 \pm 1 \\
(4)\end{array}$ & $\begin{array}{l}\text { NP } \\
(2)\end{array}$ & $\begin{array}{c}27 \pm 2 \\
(2)\end{array}$ \\
\hline Eriophorum vaginatum & $\begin{array}{c}35 \pm 3 \\
(25)\end{array}$ & $\begin{array}{c}59 \pm 3 \\
(21)\end{array}$ & $\begin{array}{l}\text { NP } \\
(20)\end{array}$ & $\begin{array}{c}73 \pm 7 \\
(19)\end{array}$ & $\begin{array}{c}49 \pm 5 \\
(18)\end{array}$ & $\begin{array}{c}81 \pm 8 \\
\quad(18)\end{array}$ & $\begin{array}{c}23 \pm 7 \\
(18)\end{array}$ \\
\hline Carex bigelowii & $\begin{array}{c}106 \pm 11 \\
(77)\end{array}$ & $\begin{array}{c}126 \pm 11 \\
(106)\end{array}$ & $\begin{array}{c}134 \pm 17 \\
(112)\end{array}$ & $\begin{array}{c}107 \pm 5 \\
(86)\end{array}$ & $\begin{array}{c}102 \pm 11 \\
(89)\end{array}$ & $\begin{array}{c}175 \pm 6 \\
(84)\end{array}$ & $\begin{array}{c}242 \pm 16 \\
(84)\end{array}$ \\
\hline \multicolumn{8}{|l|}{ Peak-season nitrogen content ( $\mathrm{mg} / \mathrm{g}$ dry mass) } \\
\hline Betula nana & $\begin{array}{c}29 \\
(20)\end{array}$ & $\begin{array}{c}14 \pm 0.1 \\
(21)\end{array}$ & $\begin{array}{c}19 \pm 0.4 \\
(16)\end{array}$ & $\begin{array}{c}15 \pm 0.7 \\
(20)\end{array}$ & $\begin{array}{c}19 \pm 0.8 \\
(20)\end{array}$ & $\begin{array}{c}21 \pm 0.5 \\
(19)\end{array}$ & $\begin{array}{c}18 \pm 0.2 \\
(20)\end{array}$ \\
\hline Vaccinium uliginosum & $\overline{(17)}$ & $\begin{array}{l}13 \pm 0.2 \\
(16)\end{array}$ & $\begin{array}{l}16 \pm 0.1 \\
\quad(15)\end{array}$ & $\begin{array}{l}16 \pm 0.5 \\
(17)\end{array}$ & $\begin{array}{l}\text { NP } \\
(17)\end{array}$ & $\begin{array}{l}\text { NP } \\
(17)\end{array}$ & $\begin{array}{l}\text { NP } \\
(17)\end{array}$ \\
\hline Ledum palustre & $\begin{array}{c}22 \\
(15)\end{array}$ & $\begin{array}{c}13 \pm 0.2 \\
(15)\end{array}$ & $\begin{array}{c}15 \pm 0.3 \\
(13)\end{array}$ & $\begin{array}{c}16 \pm 0.3 \\
(15)\end{array}$ & $\begin{array}{c}16 \pm 0.3 \\
(15)\end{array}$ & $\begin{array}{c}18 \pm 0.2 \\
(15)\end{array}$ & $\begin{array}{c}16 \pm 0.1 \\
(16)\end{array}$ \\
\hline Vaccinium vitis-idaea & $\begin{array}{c}13 \\
(18)\end{array}$ & $\begin{array}{c}8 \pm 0.2 \\
(20)\end{array}$ & $\begin{array}{c}11 \pm 0.4 \\
(17)\end{array}$ & $\begin{array}{c}10 \pm 0.2 \\
(22)\end{array}$ & $\begin{array}{c}10 \pm 0.3 \\
(23)\end{array}$ & $\begin{array}{l}\text { NP } \\
(22)\end{array}$ & $\begin{array}{c}11 \pm 0.5 \\
(23)\end{array}$ \\
\hline Eriophorum vaginatum & $\begin{array}{c}15 \\
(16)\end{array}$ & $\begin{array}{c}8 \pm 0.2 \\
(17)\end{array}$ & $\begin{array}{l}\text { NP } \\
(16)\end{array}$ & $\begin{array}{c}15 \pm 0.6 \\
(17)\end{array}$ & $\begin{array}{c}13 \pm 0.4 \\
(17)\end{array}$ & $\begin{array}{c}17 \pm 0.7 \\
(17)\end{array}$ & $\begin{array}{c}11 \pm 0.2 \\
(17)\end{array}$ \\
\hline Carex bigelowii & $\begin{array}{c}24 \\
(37)\end{array}$ & $\begin{array}{c}10 \pm 0.3 \\
(37)\end{array}$ & $\begin{array}{c}11 \pm 0.6 \\
(35)\end{array}$ & $\begin{array}{c}17 \pm 0.8 \\
(36)\end{array}$ & $\begin{array}{c}17 \pm 0.7 \\
(36)\end{array}$ & $\begin{array}{c}13 \pm 0.7 \\
(36)\end{array}$ & $\begin{array}{l}15 \pm 1.4 \\
(37)\end{array}$ \\
\hline
\end{tabular}

mental plots twice, in June 1979 (L. Terwilliger, personal observation) and in mid-July 1979 (Linkins and Neal 1982). Oil was sprayed onto leaves and the moss surface and onto the moss surface beneath the leaves. (5) At five sites along the TAPS haul road and at Cape Thompson, shoot populations, shoot growth, and nutrient content were measured several times during the 1979 growing season under ambient conditions (P. C. Miller, personal observation). In each of the situations, the model was validated by comparing calculated and measured values for peak season new leaf and stem biomass by species, peak season nitrogen and phosphorus contents by species, nitrogen and phosphorus uptake by species, ecosystem respiration, and net ecosystem production.

\section{Validation experiments at Eagle Creek}

Ambient conditions. - A relatively complete set of measurements was available from research at Eagle Creek and was used to validate ARTUS (Table 11). These measurements included thaw depth (P. C. Miller and P. M. Miller, personal observation), evapotrans- piration (Stuart et al. 1982), soil moisture (S. A. Barkley and J. Kellogg, personal observation), ecosystem respiration (Poole and Miller 1982), leaf and stem production (L. Stuart and P. C. Miller, personal observation), leaf nitrogen content (L. Stuart and P. C. Miller, personal observation), total community root length (Miller et al. 1982), average root length to mass ratios (Miller et al. 1982), nitrogen mineralized (Marion and Miller 1982), vascular plant nitrogen uptake (Marion et al. 1982, Stuart and Miller 1982), and soil solution nitrogen (S. A. Barkley and J. Kellogg, personal observation). In addition moss nitrogen uptake was estimated from moss biomass turnover and nitrogen contents of green and brown moss tissues.

Final thaw depth at Eagle Creek was simulated within $20 \%$ of the measured value (Table 11). The simulated rate of thaw was most rapid immediately following snow-melt; then, thaw rate declined in late summer, as measured and predicted at other tundra sites (Nakano and Brown 1972, Haag and Bliss 1974). Similarly, the simulated seasonal patterns of solar radiation, soil temperature, and soil water content closely matched 
measured values (Chapin et al. 1979, Stuart and Miller 1982), indicating that ARTUS successfully simulated the seasonality of the physical environment. Simulated ecosystem respiration was also within the range of measured values. The simulated value for total vascular plant production was $77 \%$ of the measured value, due to low predicted productivity of each component species except Carex bigelowii. Eriophorum vaginatum and the deciduous shrubs Betula nana and Vaccinium uliginosum had simulated production values closest to measured values and showed simulated seasonal patterns of leaf biomass quite similar to those measured at Eagle Creek (Miller et al. 1982) and elsewhere (Chapin et al. 1980). In all of these species, simulations showed a spring decline in total nonstructural carbohydrate (TNC), coincident with leaf initiation, followed by recovery of TNC levels in autumn. These patterns were more pronounced in the deciduous shrubs with their synchronous leaf production than in $E$. vaginatum, which exhibits asynchronous leaf production and turnover. The simulated patterns of total nonstructural carbohydrate and biomass closely match those documented for tundra plants (McCown 1978). Both the seasonal patterns for total nonstructural carbohydrate and biomass and the total annual production were less successfully simulated for $C$. bigelowii and the evergreen shrubs, indicating a need for further research on these species.

The simulated seasonal pattern of nitrogen mineralization closely parallels the seasonal pattern of soil temperature, which is consistent with the conclusion that temperature is the major factor limiting mineralization rate in tundra (Marion and Miller 1982). In contrast, the simulated seasonal pattern of nitrogen uptake more closely parallels the seasonal pattern of root growth, which is consistent with the idea that root surface area is the major factor determining nutrient uptake by plants (Nye and Tinker 1977) and that uptake by tundra plants is relatively insensitive to soil temperature (Chapin and Bloom 1976).

Total simulated community root length was less than was measured, by a factor of 10 (Table 11), indicating that, as in most ecosystems, much more needs to be learned about controls over root biomass and production in tussock tundra. The root : shoot ratio in ARTUS was the ratio of absorbing root to new leaf plus new stem. Because of low simulated values for root biomass, simulated nitrogen uptake did not significantly affect soil inorganic nitrogen concentration, and simulated nitrogen values were less than measured values for some species. Simulated plant nitrogen and phosphorus concentrations were similar to measured values for all species for which data were available except for high phosphorus concentrations in deciduous shrubs.

Dry-fertilizer experiments. - Fertilization with dry fertilizer did not affect the growth of vascular plants until the 2 nd yr after the addition. Nitrogen alone increased growth more than did phosphorus alone, but both together gave the largest response (Shaver and Chapin 1980).

Dry-fertilizer addition was simulated by adding nitrogen at a rate of either 5 or $15 \mathrm{~g} / \mathrm{m}^{2}$ to the green moss layer on 1 July. Fertilizer was moved into the soluble inorganic compartment, taken up by green moss and vascular plants, mineralized, and leached to the next soil layer below. In the simulation the addition of dry fertilizer had little effect on shoot production or nitrogen uptake by the end of the summer season.

Off-road vehicle experiments. - Off-road vehicle tracks leave a signature on the tundra because of the compression of the organic mat, loss of standing dead, and increased production. Carbon dioxide evolution increased by two times in vehicle tracks (Stuart and Miller 1982). The surface of the organic mat subsides, and production and nutrient uptake in the track are increased (Challinor and Gersper 1975, Chapin and Shaver 1981).

Off-road vehicles were simulated in ARTUS by reducing leaf, root, and stem biomass; increasing the bulk density of the organic mat; and increasing the rates of decomposition. The simulated off-road vehicle passes occurred on 15 June and 15 July. The model can allow vehicle damage to occur at three levels of intensity on any day in the growing season. Field data indicate that leaf drop and stem breakage of species were increasingly sensitive to off-road vehicles in the sequence: $V$. uliginosum, B. nana, L. palustre, $V$. vitis-idaea, E. vaginatum, and C. bigelowii (J. Kummerow, personal observation). The simulations with ARTUS indicated the same sequence of sensitivity of species to off-road vehicle passes. The results of off-road vehicle and oil spill simulations were similar and will be discussed in the next section.

Oil spill experiments. - Leaf production was measured in the June spills (L. Terwilliger, personal $o b$ servation, 1980), and ecosystem respiration and leaf production were measured in the mid-July oil spill (A. E. Linkins, personal observation). The mid-July application of ambient-temperature crude oil at $20 \mathrm{~L} / \mathrm{m}^{2}$ had an immediate effect on the growth and production of both the graminoid $E$. vaginatum, and the deciduous shrub $B$. nana. Within $10 \mathrm{~d}$ leaf and root death had occurred on plants contacted by oil. Soil respiration immediately decreased $75 \%$ in the $15 \mathrm{~cm}$ of soil that was permeated by the oil. Soil enzyme activity of cellulase and phosphomonoesterase did not decrease (Linkins and Neal 1982). Total E. vaginatum cover, which was measured the second summer season after the oil application, decreased by $50 \%$, but water potential and root respiration measurements on viable $E$. vaginatum leaves and roots in the oil treatment plots did not differ from control plants. The number of viable mycorrhizal roots and respiration of viable roots in $B$. nana decreased significantly, but leaf water potentials did not change. During the second summer significant early leaf death was observed in July in the oil-treated 
TABLE 12. The effect of changes in species composition on biomass compared to biomass of the standard case where all six vascular species plus moss were present. Species codes: $L=$ Ledum palustre, $V v-i=$ Vaccinium vitis-idaea, $C=C a r e x$ bigelowii, $E=$ Eriophorum vaginatum, $B=$ Betula nana, and $V u=V a c c i n i u m$ uliginosum. The first four columns represent changes in community composition as the result of trampling or off-road vehicles; the fifth column represents early stages of recovery; the sixth column represents recovery after total removal of the previous vegetation.

\begin{tabular}{|c|c|c|c|c|c|c|}
\hline \multirow[b]{2}{*}{ Taxon } & \multicolumn{6}{|c|}{ Community composition } \\
\hline & $\begin{array}{l}\text { Standard } \\
\text { case }\end{array}$ & $\begin{array}{l}L V v-i \\
C E\end{array}$ & $C E$ & $C$ & $\begin{array}{l}B V u \\
C E\end{array}$ & $E$ \\
\hline \multicolumn{7}{|c|}{ Dry biomass $\left(\mathrm{g} \cdot \mathrm{m}^{2} \cdot \mathrm{yr}^{-1}\right)$} \\
\hline Betula nana & 2.2 & & & & 2.5 & \\
\hline Vaccinium uliginosum & 1.6 & & & & 2.1 & \\
\hline Ledum palustre & 16.7 & 16.7 & & & & \\
\hline Vaccinium vitis-idaea & 36.7 & 37.4 & & & & \\
\hline Carex bigelowii & 9.6 & 9.6 & 12.9 & 13.6 & 13.0 & \\
\hline Eriophorum vaginatum & 31.6 & 41.9 & 54.1 & & 38.9 & 62.9 \\
\hline Moss & 117 & 118 & 109 & 107 & 108 & 109 \\
\hline Net ecosystem production & 120 & 128 & 81 & 26 & 69 & 77 \\
\hline
\end{tabular}

plots, and soil respiration and cellulase activity, especially of exocellulase, were significantly reduced in soil where oil was present. Phosphomonoesterase activity did not seem to be affected.

Oil has generally been shown to reduce fungal activity and kill leaves on contact (Babb and Bliss 1974, Linkins and Antibus 1978). Linkins et al. (1978) found that in the coastal tundra at Barrow, Alaska, active root mass and number of shoots were reduced and senescence occurred earlier in the season for $2 \mathrm{yr}$ after oil spill. However, tussock tundra seems to be better able to recover from moderate oil spills than does most coastal tundra. This rapid recovery is probably due to the thickness of the organic horizon in tussock tundra, the relatively limited penetration of the oil within the organic horizon, and the ability of $E$. vaginatum roots to grow through the oiled soil horizon and function normally as measured by root growth, morphology, and respiration.

Oil was added in the ARTUS simulations on 15 June and 15 July. The oil spill was simulated by reducing the leaf mass of all species, reducing the mycorrhizal factor, and reducing the decomposition of cellulose. No new leaf growth was allowed for $7 \mathrm{~d}$ after the oil spill to simulate the persistence of volatile compounds. Water stress developed depending on the heat stress and water-absorbing surface of the plant.

Compared to the standard case, the simulated offroad vehicle and oil spill perturbations reduced the depth of thaw and ecosystem respiration. Total vascular-plant production was reduced more by the 15 June off-road vehicle passage than by the 15 July passage. However, new leaf and new stem production in the remaining shoots was twofold greater after the June off-road vehicle perturbation, which left time for leaf and stem mass to recover. Shoot production in the evergreen shrubs did not recover after either oil spill treatment. Evergreen shrubs lost all old leaves, and sugar reserves fell quickly to near zero, which did not allow regrowth of new leaves or continued root growth.
In the simulated off-road vehicle perturbations, absorbing root lengths of all species except Carex bigelowii were reduced because the number of shoots was reduced. With oil spill the effective root lengths were reduced due to the loss of mycorrhizae. C. bigelowii was little affected by the simulated off-road-vehicle and oil spill perturbations. The only effect built into the model was defoliation, from which the sedge rapidly recovered. Nitrogen uptake in $C$. bigelowii was higher with oil spills than under normal ambient conditions because its effective root length and number of shoots per square metre were unaltered, while uptake by other species was eliminated.

Simulated peak season absorbing-root lengths were similar and higher with a 15 July off-road-vehicle passage and oil spill than with 15 June perturbations. The reasons for the increased root lengths with the lateseason perturbations were unclear. However, nitrogen uptake did not follow this trend.

In the simulations off-road vehicles had no effect on the moss per se, but the defoliation of vascular plants decreased shading and allowed $D$. elongatum to increase in biomass instead of slowly declining through the season as it did with simulated ambient conditions. In ARTUS oil spill killed the moss tissue, but a lateseason spill allowed the accumulation of more moss tissue before death occurred.

Slightly more water drained from the soil after compression in the simulated off-road-vehicle perturbations. This effect was more pronounced earlier in the season when the lower soil horizons had not thawed, because water ran off the surface instead of moving down into the less compressed lower horizons.

\section{Changes in community composition}

The sensitivity of ARTUS to community composition was tested by varying the species present in the community (Table 12). Species were included or excluded in a series of simulations according to a hypothetical scenario of the effects of trampling and off- 
road vehicles. Based on general field observations, the deciduous shrubs appear to be the most sensitive to the effects of trampling and off-road vehicles, $E$. $v a$ ginatum the next most sensitive, then evergreen shrubs, and finally $C$. bigelowii. In the ARTUS simulations of the degradation of tussock tundra, species composition was changed from the standard case where all six vascular plant species were present to a community composed of L. palustre, V. vitis-idaea, C. bigelowii, and $E$. vaginatum, to a community with only $C$. bigelowii and $E$. vaginatum present, and finally to a pure stand of $C$. bigelowii. Field observations indicate that after disturbance $E$. vaginatum increases first, followed by the deciduous shrubs. During the early stages of recovery, the simulated community contained $B$. nana, $V$. uliginosum, $C$. bigelowii, and $E$. vaginatum. A pure stand of $E$. vaginatum was also simulated because $E$. vaginatum often occurs in almost pure stands if the previous vegetation has been removed down to the mineral soil.

Changing the species present in the tussock tundra community simulated by ARTUS had variable effects and indicated that the deciduous shrubs $B$. nan $a$ and $V$. uliginosum contribute little to the net ecosystem production. The presence or absence from the community of either of the two sedges, $C$. bigelowii and $E$. vaginatum, only changed net ecosystem production by the amount of their contribution. In contrast to the insensitivity of the community to deciduous shrubs or sedges, the absence of the evergreen shrubs, L. palustre and $V$. vitis-idaea, had a significant effect on net ecosystem production and nitrogen uptake by the remaining species. In ARTUS simulations, the presence of evergreen shrubs seems to suppress production in deciduous shrubs and sedges; evergreen shrubs seem to be a key factor in controlling certain functions of the tussock tundra ecosystem. These simulations of species removal indicated only short-term responses, which were limited by the shoot densities. If ARTUS was run for several years, allowing shoot densities to change, more growth by remaining species should occur.

Validation in north-central and northwestern Alas$k a$. - The best set of data available for extensive validation of ARTUS was the vascular plant biomass and nutrient content data obtained from sites along the TAPS haul road and at Cape Thompson, even though the seasonal course of environmental data was lacking for most of these sites (Haugen and Brown 1978) (Table 1). Simulated values for thaw depth, ecosystem respiration, peak season leaf and stem production, and nitrogen and phosphorus contents were compared to measured values from these sites (Table 11). Thaw depths were measured by P. C. Miller and P. M. Miller (personal observation) and by Everett (1981) by making 25 probes in tussock and intertussock areas with a metal rod. Thaw depths were not measured at the Timberline site because of the rocky soils. Measured thaw depths were not shallower at the northern sites com- pared to Eagle Creek probably because organic matter and ice contents were highly variable where depth of thaw was measured. Ecosystem respiration measurements were similar at sites south and north of the Brooks Range (Poole and Miller 1982). Peak values of new aboveground biomass, not including secondary growth of woody stems, were measured in 1979 by P. C. Miller et al. (personal observation). New biomass included new leaf and new stem material of $B$. nana, $V$. uliginosum, L. palustre, and $V$. vitis-idaea and new leaf material only for $E$. vaginatum and $C$. bigelowii. Biomass was measured on four composite samples collected from 25 individuals of each species. Shoot densities were measured at each site. These data indicated that production per shoot at Toolik Lake and Sagwon was about half that at the Old Man and Timberline sites. Nitrogen and phosphorus contents of new biomass were usually slightly higher at the northern two sites.

The simulated thaw depths were deeper than those measured at all sites (Table 11). The lack of agreement between similated and measured values may be the result of improper climatic modeling, improper relations between peak thaw and annual mean temperature, or improper values for organic layer thicknesses. Thaw depth varies more with ice and water content of the organic mat than with latitude. At Devon Island $\left(75^{\circ} \mathrm{N}\right)$, thaw depth of the wet meadow and the drained beach ridge was similar to thaw depth measured in the same soil types at Barrow $\left(72^{\circ} \mathrm{N}\right)$ and Eagle Creek $\left(65^{\circ} \mathrm{N}\right)$ (Bliss 1977, Brown et al. 1980). Solar irradiances on the north slope may be overestimated because climatic data from Eagle Creek were used as driving variables for all sites.

The measured values for ecosystem respiration at the four sites along the TAPS haul road were $\approx 50 \%$ larger than the simulated values (Poole and Miller 1982). The measured values were corrected by a factor of 1.41 to account for water displaced from the $\mathrm{NaOH}$ (K. Van Cleve, personal communication). Simulated and measured ecosystem respiration decreased in the northward direction at a similar rate.

Simulated total vascular-plant production was lower than the measured amounts at all sites except Old Man. On a per-shoot basis, simulated production was lower than measured values for all species at all sites except C. bigelowii, which was higher at all sites. Simulated leaf and stem nitrogen contents were close to the measured values at all sites for all species except $C$. bigelowii, which had consistently high simulated nitrogen contents at all sites.

\section{Simulated Summer Heat, Water, Carbon,} Nitrogen, AND Phosphorus Budgets

\section{Heat budget}

ARTUS was used to calculate budgets for heat, water, carbon, nitrogen, and phosphorus during the summer 
TABLE 13. Summary of simulated summer heat, water, and carbon budgets: 1 May to 17 September.

\begin{tabular}{|c|c|c|c|c|c|c|c|}
\hline & \multirow{2}{*}{$\begin{array}{l}\text { Eagle } \\
\text { Creek }\end{array}$} & \multirow[b]{2}{*}{ Old Man } & \multirow[b]{2}{*}{ Timberline } & \multirow[b]{2}{*}{ Toolik } & \multirow[b]{2}{*}{ Sagwon } & \multicolumn{2}{|c|}{ Cape Thompson } \\
\hline & & & & & & East & West \\
\hline \multicolumn{8}{|l|}{ Heat budget $\left(\mathrm{MJ} \cdot \mathrm{m}^{-2} \cdot \mathrm{yr}^{-1}\right)$} \\
\hline Solar incoming & 2115 & 2115 & 2115 & 2115 & 2115 & 2115 & 2115 \\
\hline Solar reflected & 381 & 381 & 381 & 381 & 381 & 381 & 381 \\
\hline Infrared net loss & 892 & 884 & 884 & 899 & 899 & 903 & 903 \\
\hline Evaporative heat loss & 438 & 410 & 240 & 338 & 338 & 358 & 358 \\
\hline \multicolumn{8}{|l|}{ Water budget $(\mathrm{mm} / 5 \mathrm{mo})$} \\
\hline Precipitation & 245 & 245 & 245 & 245 & 245 & 245 & 245 \\
\hline Evapotranspiration & 180 & 168 & 98 & 139 & 139 & 147 & 147 \\
\hline Runoff and drainage & 170 & 232 & 311 & 165 & 165 & 254 & 254 \\
\hline Potential evapotranspiration & 567 & 586 & 582 & 524 & 523 & 524 & 524 \\
\hline \multicolumn{8}{|l|}{ Dry-mass carbon budget $\left(\mathrm{g} \cdot \mathrm{m}^{-2} \cdot \mathrm{yr}^{-1}\right)$} \\
\hline Gross primary production & 610 & 609 & 596 & 373 & 367 & 405 & 425 \\
\hline Net primary production & 215 & 197 & 177 & 142 & 135 & 178 & 151 \\
\hline Decomposition & 95 & 52 & 14 & 30 & 21 & 22 & 22 \\
\hline Net ecosystem production & 120 & 145 & 163 & 111 & 114 & 156 & 129 \\
\hline \multicolumn{8}{|l|}{ Respiration } \\
\hline Vascular plant & 95 & 80 & 35 & 27 & 17 & 24 & 24 \\
\hline Moss & 21 & 28 & 30 & 17 & 17 & 15 & 15 \\
\hline Litterfall (shrub leaf and stem) & 85 & 20 & 21 & 14 & 13 & 11 & 25 \\
\hline New standing dead (graminoid leaf) & 21 & 7 & 5 & 11 & 9 & 27 & 12 \\
\hline Total vascular plant production & 98.5 & 88.4 & 69.5 & 34.2 & 28.1 & 69.7 & 42.8 \\
\hline Betula nana & 2.2 & 2.7 & 48.3 & 3.8 & 6.7 & 21.1 & 11.3 \\
\hline Vaccinium uliginosum & 1.6 & 63.9 & 4.0 & 1.9 & 0.0 & 0.0 & 0.0 \\
\hline Ledum palustre & 16.7 & 1.2 & 2.6 & 3.6 & 2.8 & 1.7 & 10.5 \\
\hline Vaccinium vitis-idaea & 36.7 & 2.9 & 1.8 & 1.5 & 1.4 & 0.0 & 0.0 \\
\hline Eriophorum vaginatum & 31.6 & 2.4 & 0.0 & 5.6 & 8.7 & 42.2 & 17.8 \\
\hline Carex bigelowii & 9.6 & 15.2 & 12.8 & 18.0 & 8.6 & 4.6 & 3.3 \\
\hline Total moss production & 116.9 & 108.2 & 107.4 & 107.3 & 106.7 & 108.0 & 108.1 \\
\hline Sphagnum capilaceum & 52.4 & 48.0 & 47.7 & 47.8 & 47.5 & 48.1 & 48.2 \\
\hline Dicranum elongatum & 27.3 & 25.1 & 24.9 & 24.9 & 24.8 & 25.1 & 25.1 \\
\hline Polytrichum commune & 25.1 & 24.1 & 24.0 & 23.7 & 23.6 & 23.9 & 23.9 \\
\hline Other & 12.1 & 10.9 & 10.8 & 10.9 & 10.8 & 10.9 & 11.0 \\
\hline
\end{tabular}

active season (the "year") for the research sites at Eagle Creek, Old Man, Timberline, Toolik Lake, Sagwon, and Cape Thompson. Based on measured values for Eagle Creek, incoming solar irradiance averaged 15.1 $\mathrm{MJ} \cdot \mathrm{m}^{-2} \cdot \mathrm{d}^{-1}$ or $2115 \mathrm{MJ} \cdot \mathrm{m}^{-2} \cdot \mathrm{yr}^{-1}$ (Table 13). Irradiance on the north slope of the Brooks Range is about two-thirds of that received on the south slope because of increased cloudiness. The input of solar irradiance was not reduced in these simulations because of the lack of data on solar irradiance at sites along the TAPS haul road. The value for irradiance used in ARTUS is comparable to the average value of $10 \mathrm{MJ} \cdot \mathrm{m}^{-2} \cdot \mathrm{d}^{-1}$, which was measured at Barrow (Dingman et al. 1980). The albedo of tussock tundra was $\approx 20 \%$ (Stuart et al. 1982), which gave $381 \mathrm{MJ} \cdot \mathrm{m}^{-2} \cdot \mathrm{yr}^{-1}$ reflected solar irradiance. The measured infrared irradiances from the sky averaged $21 \mathrm{MJ} \cdot \mathrm{m}^{-2} \cdot \mathrm{d}^{-1}(\mathrm{~L}$. Stuart and P. C. Miller, personal observation). The upward flux of infrared irradiance was $27 \mathrm{MJ} \cdot \mathrm{m}^{-2} \cdot \mathrm{d}^{-1}$. The average measured net infrared loss was $\approx 600 \mathrm{MJ} / \mathrm{m}^{2}$ for the summer (1 May to 17 September). Infrared loss from tussock areas was $\approx 1 \mathrm{MJ} \cdot \mathrm{m}^{-2} \cdot \mathrm{d}^{-1}$ higher than that from intertussock areas. Simulated net infrared loss was $892 \mathrm{MJ} / \mathrm{m}^{2}$ for the summer at Eagle Creek. Simulated heat loss by evaporation was $438 \mathrm{MJ} / \mathrm{m}^{2}$ at Eagle Creek. Less heat was lost by evaporation on the North Slope because of lower temperatures and a shorter growing season. The simulated evaporation was probably too high. In the wet meadow at Barrow, evaporation accounted for $\approx 500 \mathrm{MJ} \cdot \mathrm{m}^{-2} \cdot \mathrm{yr}^{-1}$ of the total incoming solar irradiance. Conduction into the soil from 1 May to 15 September should be $\approx 126 \mathrm{MJ} / \mathrm{m}^{2}$ and was not simulated correctly because the summer heat budget did not include heat used in melting snow, which could be $20 \mathrm{MJ} / \mathrm{m}^{2}$. Convection, calculated as the remainder, should be $\approx 82 \mathrm{MJ} \cdot \mathrm{m}^{-2} \cdot \mathrm{yr}^{-1}$.

\section{Water budget}

Precipitation measured through the summer season at Eagle Creek was $245 \mathrm{~mm}$. In the simulations precipitation was kept constant at all sites. Potential evapotranspiration was $\approx 2.4 \mathrm{~mm} / \mathrm{d}$ at midseason or $\approx 240 \mathrm{~mm}$ for the summer (Stuart et al. 1982). Simulated evapotranspiration was $180 \mathrm{~mm}$ at Eagle Creek and decreased to $98 \mathrm{~mm}$ at Timberline (Table 13). The highest rates of evapotranspiration occurred during midsummer. Measured evapotranspiration was $\approx 120$ $\mathrm{mm}$ at Eagle Creek, which was similar to the 70-140 mm estimated for Barrow (Dingman et al. 1980). Other daily rates for potential and actual evapotranspiration, 
respectively, are 3.1 and $1.9 \mathrm{~mm} / \mathrm{d}$ at Devon (Ryden 1981), 2.8 and $2.6 \mathrm{~mm} / \mathrm{d}$ at Barrow (Dingman et al. 1980), 3.6 and $1.9 \mathrm{~mm} / \mathrm{d}$ at Igarka, USSR, and 5.3 and $1.8 \mathrm{~mm} / \mathrm{d}$ at Vorkuta, USSR (Pavlov 1976). Drainage loss simulated in ARTUS ranged between $165 \mathrm{~mm}$ at Toolik and Sagwon, and $311 \mathrm{~mm}$ at Timberline, because of large amounts of excess water early in the season.

\section{Carbon budget}

Gross primary production of dry mass calculated using ARTUS was $\approx 610 \mathrm{~g} / \mathrm{m}^{2}$ at Eagle Creek (Table 13). Gross primary production was higher at Old Man and Timberline than at Toolik, Sagwon, and Cape Thompson, probably due to the shorter growing season and smaller plant biomass at the northern sites. The simulated values for gross primary production for Cape Thompson were close to the value reported for Barrow; $465 \mathrm{~g} \cdot \mathrm{m}^{-2} \cdot \mathrm{yr}^{-1}$ (Miller et al. 1981). Calculated net primary production was $215 \mathrm{~g} \cdot \mathrm{m}^{-2} \cdot \mathrm{yr}^{-1}$ at Eagle Creek. The relatively low net primary production that was simulated for Timberline may be caused by high respiration, which in turn relates to the predominance of woody shrubs at Timberline. These values can be compared to measurements at Barrow, Alaska, where net primary production was $240 \mathrm{~g} \cdot \mathrm{m}^{-2} \cdot \mathrm{yr}^{-1}$, including 162 $\mathrm{g} \cdot \mathrm{m}^{-2} \cdot \mathrm{yr}^{-1}$ for vascular plants and $66 \mathrm{~g} \cdot \mathrm{m}^{-2} \cdot \mathrm{yr}^{-1}$ for mosses.

Simulated carbon budgets for the vascular plants indicated dry mass production of $99 \mathrm{~g} \cdot \mathrm{m}^{-2} \cdot \mathrm{yr}^{-1}$ at Eagle Creek (Table 13). Vascular plant production decreased northward. Carbon budgets for the mosses indicated production rates of $107-117 \mathrm{~g} \cdot \mathrm{m}^{-2} \cdot \mathrm{yr}^{-1}$ at all sites.

Simulated carbon budgets for the dead organic material indicated accumulation, particularly of the longchain recalcitrant compounds. At Eagle Creek, litterfall introduced $\approx 85 \mathrm{~g} / \mathrm{m}^{2}$ annually into the dead organic pool, which included $\approx 8 \mathrm{~g} / \mathrm{m}^{2}$ of lignin, $16 \mathrm{~g} / \mathrm{m}^{2}$ each of cellulose and hemicellulose, and $2 \mathrm{~g} / \mathrm{m}^{2}$ of protein. Litterfall was much lower at the other sites. Decomposition accounted for $95 \mathrm{~g} / \mathrm{m}^{2}$ at Eagle Creek, which included none of the lignin, some of the cellulose and hemicellulose, and all of the protein. In the simulations $\approx 6 \mathrm{~g} / \mathrm{m}^{2}$ of storage carbohydrates were added to the soil in litterfall each year, but they decomposed within 2 wk of snowmelt.

Simulated decomposition of dry matter was 95 $\mathrm{g} \cdot \mathrm{m}^{-2} \cdot \mathrm{yr}^{-1}$ at Eagle Creek, which gave a rate of accumulation of organic matter, or net ecosystem drymatter production, of $120 \mathrm{~g} \cdot \mathrm{m}^{-2} \cdot \mathrm{yr}^{-1}$. Decomposition was lower at the TAPS haul road sites. All simulated values for net ecosystem production or dry-matter accumulations are unrealistically high. Decomposition was probably low at Timberline due to inaccurate consideration of the effects of waterlogging on decomposition in the mineral soil. The reasons for the low decomposition rates at the other sites were unclear.
Carbon-14 dates on organic matter (K. R. Everett, personal observation) indicated rates of accumulation of dry matter of $20-40 \mathrm{~g} \cdot \mathrm{m}^{-2} \cdot \mathrm{yr}^{-1}$ in tussock tundra. Simulated litter production, which included shrub leaf and stem material and standing dead graminoid leaf material, was higher than decomposition and lower than net primary production, indicating increased biomass along with the increased soil organic matter.

\section{Nitrogen budget}

Nitrogen fixation has not been measured in tussock tundra; the annual value for wet meadow at Barrow, $0.07 \mathrm{~g} / \mathrm{m}^{2}$, was used in the ARTUS simulations (Van Cleve 1974, Gersper et al. 1980, Van Cleve and Alexander 1981). Wet plus dry fall nitrogen was assumed to be $0.05 \mathrm{~g} \cdot \mathrm{m}^{-2} \cdot \mathrm{yr}^{-1}$ based on measurements made by G. M. Marion (personal observation) at Eagle Creek and along the TAPS haul road. Van Cleve and Alexander (1981) gave values of this magnitude for Fairbanks, Stordalen, and Glenamoy, but values for Devon and Barrow were $10 \times$ lower. In ARTUS the loss of nitrogen by drainage occurred mainly at soil thaw. We used $0.2 \mathrm{mg} / \mathrm{L}$ as the simulated soil solution nitrogen during the period of thaw. A field measurement of soil solution nitrogen was $1.2 \mathrm{mg} / \mathrm{L}$ on 15 June (S. A. Barkley and J. Kellogg, personal observation), but if we simulated using a concentration of $1.2 \mathrm{mg} / \mathrm{L}$ during the period of thaw, an unrealistically high drainage loss of nitrogen would occur. It is postulated that during the winter, nitrogen compounds break down into shortchain organic forms and become readily available for microbial use and for release into inorganic forms during soil thaw. At soil thaw a burst of microbial activity occurs, releasing a pulse of $\mathrm{CO}_{2}$, as seen by Gosink and Kelly (1979). In the simulations root growth lagged soil thaw. After $\approx 2$ wk root growth and uptake began to lower the amount of inorganic nitrogen in the soil solution.

The simulated loss of nitrogen was $0.02 \mathrm{~g} \cdot \mathrm{m}^{-2} \cdot \mathrm{yr}^{-1}$ at Eagle Creek (Table 14). Mineralization occurred almost wholly in the organic layers, mostly in the hemic and sapric layers. There was very little mineralization in the mineral soil. Mineralization decreased in the northward direction and was unrealistically low at Timberline. The mineralization model was based on measurements in the waterlogged soils at Eagle Creek and may not be valid for better-drained soils at the Timberline site.

The values simulated for nitrogen uptake by vascular plants were reasonable, but nitrogen uptake by mosses was low. The annual incorporation of nitrogen into moss tissue should be $\approx 0.6 \mathrm{~g} / \mathrm{m}^{2}$. The mass flow of nitrogen to the moss because of evaporation only supplied $\approx 0.05 \mathrm{~g} / \mathrm{m}^{2}$ of the total. The main period of evaporation and mass flow was midsummer when soil solutions contained only $0.1 \mathrm{mg} / \mathrm{L}$ of nitrogen. Other processes that were not included in ARTUS, such as diffusion in the soil solution and nitrogen fixation by 
TABLE 14. Summary of simulated nitrogen budget. Units are $\mathrm{g} \cdot \mathrm{m}^{-2} \cdot \mathrm{yr}^{-1}$.

\begin{tabular}{|c|c|c|c|c|c|c|c|}
\hline & \multirow{2}{*}{$\begin{array}{l}\text { Eagle } \\
\text { Creek }\end{array}$} & \multirow[b]{2}{*}{ Old Man } & \multirow[b]{2}{*}{ Timberline } & \multirow[b]{2}{*}{ Toolik } & \multirow[b]{2}{*}{ Sagwon } & \multicolumn{2}{|c|}{ Cape Thompson } \\
\hline & & & & & & East & West \\
\hline \multicolumn{8}{|l|}{ Flows into and out of system } \\
\hline \multicolumn{8}{|l|}{ Input } \\
\hline Nitrogen fixation & 0.00 & 0.00 & 0.00 & 0.00 & 0.00 & 0.00 & 0.00 \\
\hline Atmospheric dry and wet fall & 0.05 & 0.05 & 0.05 & 0.05 & 0.05 & 0.05 & 0.05 \\
\hline \multicolumn{8}{|l|}{ Output } \\
\hline Drainage & 0.02 & 0.02 & 0.03 & 0.02 & 0.02 & 0.03 & 0.03 \\
\hline Released on thaw & 0.70 & 0.93 & 0.98 & 0.50 & 0.51 & 0.98 & 0.98 \\
\hline Mineralized total & 1.85 & 1.01 & 0.27 & 0.58 & 0.41 & 0.42 & 0.42 \\
\hline 1. Fibric & 0.17 & 0.11 & 0.03 & 0.06 & 0.06 & 0.06 & 0.06 \\
\hline 2. Hemic & 1.09 & 0.46 & 0.15 & 0.27 & 0.18 & 0.18 & 0.18 \\
\hline 3. Sapric & 0.58 & 0.44 & 0.09 & 0.25 & 0.17 & 0.18 & 0.18 \\
\hline 4. Mineral & 0.01 & 0.00 & 0.01 & 0.00 & 0.00 & 0.00 & 0.00 \\
\hline Uptake total & 1.07 & 1.13 & 0.60 & 0.48 & 0.43 & 0.62 & 0.61 \\
\hline Vascular plant total & 0.97 & 1.08 & 0.56 & 0.44 & 0.39 & 0.57 & 0.56 \\
\hline Betula nana & 0.05 & 0.06 & 0.45 & 0.07 & 0.13 & 0.30 & 0.17 \\
\hline Vaccinium uliginosum & 0.02 & 0.70 & 0.02 & 0.02 & 0.00 & 0.00 & 0.00 \\
\hline Ledum palustre & 0.33 & 0.03 & 0.02 & 0.09 & 0.08 & 0.04 & 0.26 \\
\hline Vaccinium vitis-idaea & 0.25 & 0.04 & 0.01 & 0.03 & 0.03 & 0.00 & 0.00 \\
\hline Eriophorum vaginatum & 0.19 & 0.02 & 0.00 & 0.03 & 0.05 & 0.19 & 0.09 \\
\hline Carex bigelowii & 0.13 & 0.24 & 0.06 & 0.20 & 0.10 & 0.03 & 0.03 \\
\hline Moss total & 0.10 & 0.04 & 0.04 & 0.04 & 0.04 & 0.05 & 0.05 \\
\hline Sphagum capillaceum & 0.05 & 0.02 & 0.02 & 0.02 & 0.02 & 0.02 & 0.02 \\
\hline Dicranum elongatum & 0.02 & 0.01 & 0.01 & 0.01 & 0.01 & 0.01 & 0.01 \\
\hline Polytrichum commune & 0.02 & 0.01 & 0.01 & 0.01 & 0.01 & 0.01 & 0.01 \\
\hline Other & 0.01 & 0.01 & 0.00 & 0.01 & 0.00 & 0.01 & 0.01 \\
\hline \multicolumn{8}{|l|}{ Litterfall or new standing dead } \\
\hline Vascular plant total & 1.30 & 0.33 & 0.29 & 0.33 & 0.27 & 0.37 & 0.38 \\
\hline Betula nana & 0.00 & 0.01 & 0.08 & 0.01 & 0.02 & 0.06 & 0.04 \\
\hline Vaccinium uliginosum & 0.00 & 0.11 & 0.01 & 0.01 & 0.00 & 0.00 & 0.00 \\
\hline Ledum palustre & 0.20 & 0.02 & 0.06 & 0.08 & 0.07 & 0.04 & 0.21 \\
\hline Vaccinium vitis-idaea & 0.87 & 0.07 & 0.05 & 0.06 & 0.06 & 0.00 & 0.00 \\
\hline Eriophorum vaginatum & 0.16 & 0.01 & 0.00 & 0.03 & 0.05 & 0.23 & 0.10 \\
\hline Carex bigelowii & 0.07 & 0.11 & 0.09 & 0.14 & 0.07 & 0.04 & 0.03 \\
\hline Moss total & 0.29 & 0.20 & 0.20 & 0.18 & 0.18 & 0.18 & 0.19 \\
\hline Sphagnum capillaceum & 0.00 & 0.00 & 0.00 & 0.00 & 0.00 & 0.00 & 0.00 \\
\hline Dicranum elongatum & 0.29 & 0.20 & 0.20 & 0.18 & 0.18 & 0.18 & 0.19 \\
\hline Polytrichum commune & 0.00 & 0.00 & 0.00 & 0.00 & 0.00 & 0.00 & 0.00 \\
\hline Other & 0.00 & 0.00 & 0.00 & 0.00 & 0.00 & 0.00 & 0.00 \\
\hline
\end{tabular}

closely associated blue-green algae, probably supply nitrogen to the mosses.

The simulated addition of nitrogen to dead organic matter through litterfall was high at Eagle Creek due to the contribution of $V$. vitis-idaea. Sixty percent of the nitrogen in plant litter was assumed to be available for decomposition in the soil, and $40 \%$ was assumed to be associated with recalcitrant compounds and effectively lost from the nitrogen cycle. Species differed in the percent of nitrogen that they lost to the soil via litterfall.

\section{Phosphorus budget}

In ARTUS mineralized phosphorus was $\approx 0.1$ of the mineralized nitrogen even though different data bases were used to calculate mineralization of the two nutrients (Table 15). Phosphorus uptake declined at the northern sites along the TAPS haul road but was higher at the two Cape Thompson sites; it also varied by species. The simulated uptake of phosphorus was great- er than the amount mineralized because of the large amount of phosphorus believed to be in the soil solution at the time of thaw.

\section{Simulated Seasonal Progressions of Plant AND SoIl Processes \\ Photosynthesis and growth}

The simulated seasonal progression of plant and soil processes indicated that ARTUS was more accurate for some variables than others. Photosynthesis calculated as milligrams $\mathrm{CO}_{2}$ uptake per gram of dry mass per day was highest in Betula nana followed by $\mathrm{Vac}$ cinium uliginosum, Eriophorum vaginatum, Carex bigelowii, Ledum palustre, and V. vitis-idaea (Fig. 5). This ranking of the simulated photosynthetic rates in the six species is in the same order as maximum photosynthetic rates measured for these species at Eagle Creek by Bigger and Oechel (1982).

Photosynthesis calculated as grams of carbon per 
TABLE 15. Summary of simulated phosphorus budget. Units are $\mathrm{g} \cdot \mathrm{m}^{-2} \cdot \mathrm{yr}^{-1}$.

\begin{tabular}{|c|c|c|c|c|c|c|c|}
\hline & \multirow{2}{*}{$\begin{array}{l}\text { Eagle } \\
\text { Creek }\end{array}$} & \multirow[b]{2}{*}{ Old Man } & \multirow[b]{2}{*}{ Timberline } & \multirow[b]{2}{*}{ Toolik } & \multirow[b]{2}{*}{ Sagwon } & \multicolumn{2}{|c|}{ Cape Thompson } \\
\hline & & & & & & East & West \\
\hline \multicolumn{8}{|l|}{ Flows into and out of system } \\
\hline \multicolumn{8}{|l|}{ Input } \\
\hline Atmospheric dry and wet fall & .0008 & .0008 & .0008 & .0008 & .0008 & .0008 & .0008 \\
\hline $\begin{array}{l}\text { Output } \\
\text { Drainage }\end{array}$ & 0039 & .0016 & 0007 & 0018 & 0015 & 0015 & 0018 \\
\hline $\begin{array}{l}\text { Drainage } \\
\text { Released on thaw }\end{array}$ & $\begin{array}{l}.0039 \\
.0639\end{array}$ & $\begin{array}{l}.0010 \\
.0649\end{array}$ & .0563 & $\begin{array}{l}.0018 \\
.0399\end{array}$ & $\begin{array}{l}.0015 \\
.0378\end{array}$ & $\begin{array}{l}.0015 \\
.0626\end{array}$ & .0626 \\
\hline Mineralized total & .1848 & .1008 & .0275 & .0582 & .0408 & .0425 & .0425 \\
\hline 1. Fibric & .0168 & .0107 & .0027 & .0063 & .0062 & .0061 & .0061 \\
\hline 2. Hemic & .1092 & .0483 & .0151 & .0269 & .0177 & .0182 & .0182 \\
\hline 3. Sapric & .0583 & .0437 & .0086 & .0248 & .0169 & .0181 & .0181 \\
\hline 4. Mineral & .0005 & .0000 & .0009 & .0002 & .0000 & .0000 & .0000 \\
\hline Uptake total & .2387 & .1573 & .0829 & .0922 & .0746 & .1020 & .1014 \\
\hline Vascular plant total & .2299 & .1545 & .0804 & .0894 & .0723 & .0990 & .0983 \\
\hline Betula nana & .1072 & .0199 & .0775 & .0689 & .0663 & .0941 & .0800 \\
\hline Vaccinium uliginosum & .0255 & .1318 & .0019 & .0092 & .0000 & .0000 & .0000 \\
\hline Ledum palustre & .0725 & .0013 & .0009 & .0087 & .0044 & .0016 & .0159 \\
\hline Vaccinium vitis-idaea & .0068 & .0002 & .0000 & .0002 & .0001 & .0000 & .0000 \\
\hline Eriophorum vaginatum & .0154 & .0003 & .0001 & .0013 & .0013 & .0033 & .0023 \\
\hline Carex bigelowii & .0025 & .0009 & .0005 & .0012 & .0003 & .0001 & .0001 \\
\hline Moss total & .0088 & .0029 & .0025 & .0028 & .0023 & .0030 & .0031 \\
\hline Sphagnum capillaceum & .0041 & .0013 & .0012 & .0013 & .0011 & .0014 & .0015 \\
\hline Dicranum elongatum & .0021 & .0007 & .0006 & .0007 & .0006 & .0007 & .0008 \\
\hline Polytrichum commune & .0014 & .0005 & .0004 & .0005 & .0004 & .0005 & .0005 \\
\hline Other & .0011 & .0004 & .0003 & .0004 & .0003 & .0004 & .0004 \\
\hline Litterfall or new standing dead & .1461 & .0433 & .0406 & .0353 & .0329 & .0295 & .0431 \\
\hline Vascular plant total & .1399 & .0347 & .0299 & .0337 & .0260 & .0364 & .0360 \\
\hline Betula nana & .0059 & .0013 & .0095 & .0028 & .0032 & .0077 & .0053 \\
\hline Vaccinium uliginosum & .0016 & .0146 & .0006 & .0008 & .0000 & .0000 & .0000 \\
\hline Ledum palustre & .0274 & .0015 & .0055 & .0077 & .0060 & .0035 & .0191 \\
\hline Vaccinium vitis-idaea & .0826 & .0059 & .0051 & .0056 & .0054 & .0000 & .0000 \\
\hline Eriophorum vaginatum & .0153 & .0011 & .0091 & .0030 & .0047 & .0216 & .0091 \\
\hline Carex bigelowii & .0071 & .1040 & .0000 & .0138 & .0067 & .0036 & .0026 \\
\hline Total moss & .0286 & .0201 & .0199 & .0185 & .0183 & .0183 & .0187 \\
\hline Sphagnum capillaceum & .0000 & .0000 & .0000 & .0000 & .0000 & .0000 & .0000 \\
\hline Dicranum elongatum & .0286 & .0201 & .0199 & .0185 & .0183 & .0183 & .0187 \\
\hline Polytrichum commune & .0000 & .0000 & .0000 & .0000 & .0000 & .0000 & .0000 \\
\hline Other & .0000 & .0000 & .0000 & .0000 & .0000 & .0000 & .0000 \\
\hline
\end{tabular}

shoot per day indicated that the evergreen shrubs $L$. palustre and $V$. vitis-idaea had the highest photosynthetic rates of the six vascular species early in the summer season (Fig. 5). When leaves were produced by the deciduous shrubs $B$. nana and $V$. uliginosum, their photosynthetic rates increased but remained lower than rates of the evergreen shrubs throughout the season. The balance between carbon gain and loss is delicate, and more precise measurements are needed. Respiration losses through the winter are poorly known, and no data were available on root exudation of carbohydrates. Secondary growth was not included in ARTUS.

Simulations with ARTUS indicated three patterns of growth and of changes in storage carbohydrate. In the deciduous shrubs, leaf growth was rapid and occurred within a short period early in the season. Storage carbohydrate levels decreased during the growth flush, and root growth was depressed. In the evergreen shrubs leaf growth was slow and occurred within a relatively short period during the middle of the season. Storage carbohydrate levels increased early in the season, decreased during leaf growth, and increased again following leaf growth. Root growth began early and was slightly suppressed by low carbohydrate levels during the period of leaf growth. In the graminoids leaf growth occurred through a relatively long period and was supported by current photosynthesis. Storage carbohydrate levels remained high in $E$. vaginatum but dropped unrealistically in $C$. bigelowii. Root growth was not depressed during leaf growth in either sedge species.

In the simulated seasonal course, net primary production of vascular plants and mosses was high from early June until about 1 August (Fig. 6). Murray and Miller (1982) measured a similar pattern of leaf expansion in early June and leaf senescence beginning in early August in tussock tundra at Eagle Creek during the summers of 1977 and 1978. The difference between the net primary production curve and net ecosystem production curve is total decomposition of organic matter. In the simulations decomposition was low early 

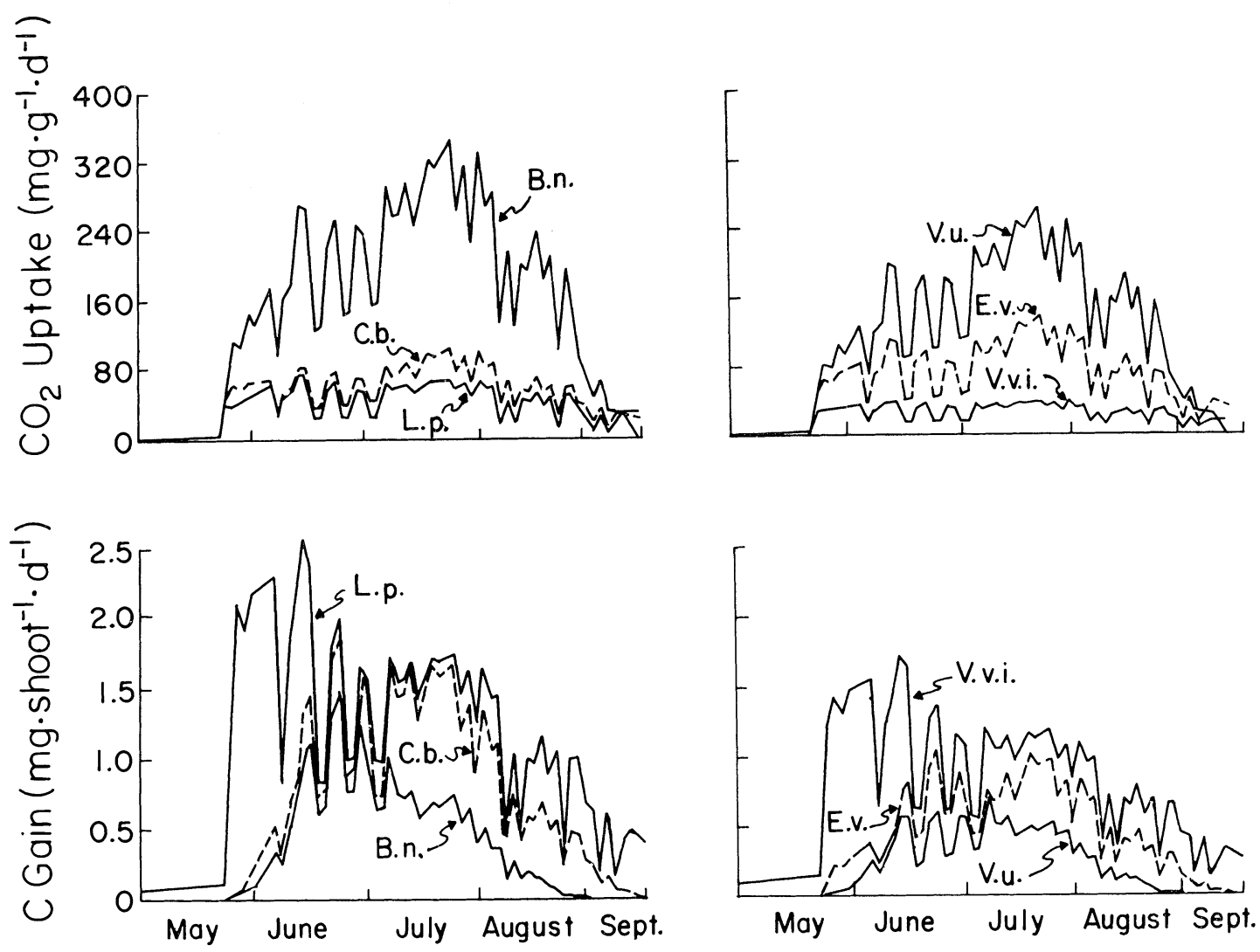

FIG. 5. Simulated seasonal course of photosynthesis measured as $\mathrm{CO}_{2}$ release and as carbon gain for Betula nana (B.n.), Carex bigelowii (C.b.), Ledum palustre (L.p.), Vaccinium uliginosum (V.u.), Eriophorum vaginatum (E.v.), and Vaccinium vitis-idaea (V.v.i.).

in the summer when temperatures were low and depth of thaw was shallow, but decomposition increased after the middle of June. Early in the season when production rates were high, tussock tundra accumulated carbon. Later in the summer, production decreased, but respiration rates remained high; net ecosystem production was negative, and carbon was lost from the system. However over the total summer season more carbon was gained than lost. In the ARTUS simulations, total ecosystem respiration peaked after the middle of July. Microbial respiration contributed more to total ecosystem respiration than did the vascular plants or mosses.

\section{Nitrogen cycling}

In the ARTUS simulations, a pulse of inorganic nitrogen was released into the soil solution when the soil solution thawed. Mineralization then proceeded relatively rapidly and used all the potentially mineralizable nitrogen within $3 \mathrm{wk}$ after thaw in the fibric horizon (Fig. 7). The amount of nitrogen in the frozen soil solution was relatively large, $0.7 \mathrm{~g} / \mathrm{m}^{2}$, and could supply a large fraction of the annual nitrogen uptake when mineralization stopped. Mineralization in the mineral soil was exceedingly low. The mineralization rates for the mineral horizon at Eagle Creek were used to calculate mineralization at the Timberline site; the resulting mineralization rates were low relative to required plant uptake rates. Mineralization rates calculated for the mineral horizon at Eagle Creek probably cannot be extrapolated to well-drained mineral soils.

The enzyme nitrogen mineralization model (Table 6) gave lower rates for nitrogen mineralization than did the incubation nitrogen mineralization model (Table 7). Simulated nitrogen uptake in $V$. vitis-idaea was high early in the season because its shallow roots took up nitrogen from the upper layers of the soil as they thawed early in the summer season. To enable $V$. vitisidaea to obtain the amount of nitrogen needed for growth, its uptake adjustment factor was large and for a short period of time gave $V$. vitis-idaea a large nitrogen uptake relative to the other species (Fig. 7). Deeperrooted shrubs had access to a more continuous nitrogen supply as deeper soil layers thawed later in the summer. In ARTUS nitrogen uptake rates increased in late summer in $V$. uliginosum and $E$. vaginatum, similar to the 

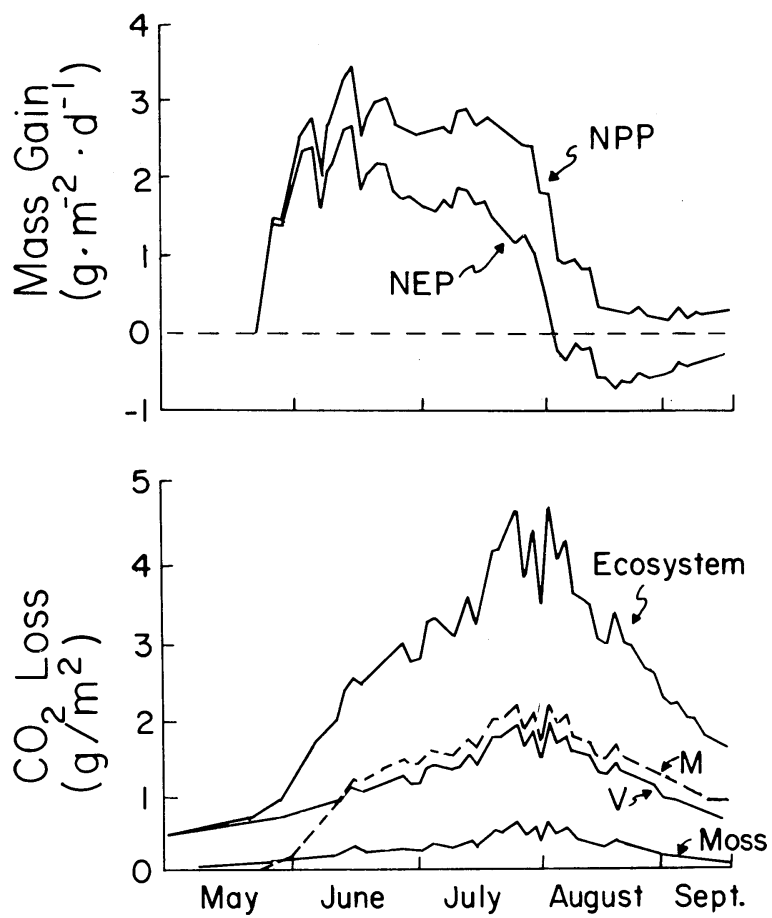

FIG. 6. Simulated seasonal course of net primary dry mass production (NPP) and net ecosystem dry mass production (NEP) and of respiration for the total ecosystem, mycorrhizae (M), vascular plants (V), and moss.

increased rates measured by L. Stuart and P. C. Miller, (personal observation).

\section{Sensitivity AnAlysis of Model}

A simple sensitivity analysis was carried out to assess the response of ARTUS to changes in a number of important variables and processes at Eagle Creek. The driving variables of temperature, irradiance, and precipitation; processes including photosynthesis, respiration, mineralization, and nutrient uptake; state variables such as organic matter thickness, initial biomass, and shoot density; and parameters including nitrogen required for new growth, nitrogen content at leaf death, and maximum potential growth rate were altered by \pm a given percentage. The sensitivity analyses were compared to the values from the ambient, standard case simulations for Eagle Creek.

The sensitivity of the responding variables to changes in climatic, soil, and species variables was calculated by subtracting the value for each responding variable from the value for the standard case and then dividing by the standard case value. The relative sensitivity of the responding variables to changes in climate, soil, and species variables was calculated as the percentage change in the responding variable divided by the percentage change of the variable modified for that particular sensitivity test. Thus relative sensitivity is a general measure of model sensitivity, which allows comparison between sensitivity runs despite differ-
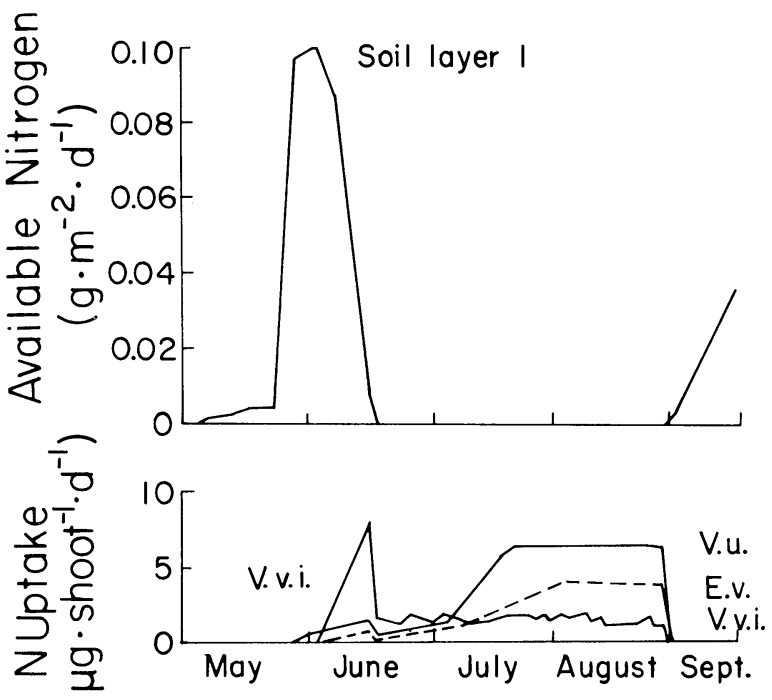

FIG. 7. Simulated seasonal course of available nitrogen in the upper layer of the soil at Eagle Creek and of nitrogen uptake by Vaccinium uliginosum (V.u.), Vaccinium vitis-idaea (V.v.i.), and Eriophorum vaginatum (E.v.).

ences in the absolute changes made in climatic, soil, or species variables for the individual sensitivity run.

\section{Sensitivity to changes in climatic variables}

Annual mean temperatures at Eagle Creek were varied by $\pm 4^{\circ} \mathrm{C}$ (Table 16). Depth of thaw increased 52\% with increased temperatures and decreased $50 \%$ with decreased temperature. Evaporation increased very little with the increased temperature but decreased with the decreased temperature. Drainage decreased by 69 $\mathrm{mm}$ with decreased temperature, although evapotranspiration decreased only $33 \mathrm{~mm}$, and precipitation was constant. The major effect of temperature may be through its effect on the length of the thawed season and the depth of the thawed soil (Billings et al. 1982). Of the parameters examined, drainage was most sensitive to temperature changes. Net vascular plant production increased $40 \%$ with a $4^{\circ}$ increase in temperature. Net moss production decreased slightly, but decomposition increased $45 \%$. With a $4^{\circ}$ decrease in temperature, net ecosystem production decreased by $17 \%$. Nitrogen mineralization increased $44 \%$ with increased temperatures, and vascular plant uptake of nitrogen increased $77 \%$, but more nitrogen was also lost through drainage. With decreased temperature less nitrogen was mineralized, taken up, and lost. Of the 26 sensitivity analyses run with ARTUS changing climatic, soil, and species variables, more responding variables showed a higher degree of relative sensitivity to increased temperature than to any other factor. The ARTUS model indicates that tussock tundra is more 
TABLE 16. Results of the sensitivity analysis of the effects of change in climatic and soil variables on ecosystem processes involving water, carbon, and nitrogen.

\begin{tabular}{|c|c|c|c|c|c|c|c|c|c|c|c|}
\hline \multirow[b]{4}{*}{ Variable responding } & \multirow{4}{*}{$\begin{array}{l}\text { Stan- } \\
\text { dard } \\
\text { case* }\end{array}$} & \multicolumn{6}{|c|}{ Climatic variable changed } & \multirow{2}{*}{\multicolumn{4}{|c|}{ Soil variable changed }} \\
\hline & & \multirow{2}{*}{\multicolumn{2}{|c|}{ Temperature }} & \multirow{2}{*}{\multicolumn{2}{|c|}{$\begin{array}{l}\text { Solar } \\
\text { irradiance }\end{array}$}} & \multicolumn{2}{|c|}{$\begin{array}{l}\text { Precipitation } \\
\text { increase }\end{array}$} & & & & \\
\hline & & & & & & \multirow{2}{*}{$\begin{array}{c}\text { Proba- } \\
\text { bility } \\
+100 \%\end{array}$} & \multirow{2}{*}{$\begin{array}{c}\text { Amount/ } \\
\mathrm{d} \\
+50 \%\end{array}$} & \multicolumn{2}{|c|}{$\begin{array}{l}\text { Initial organic } \\
\text { thickness }\end{array}$} & \multicolumn{2}{|c|}{ Mineralization } \\
\hline & & $+4^{\circ} \mathrm{C}$ & $-4^{\circ} \mathrm{C}$ & $+20 \%$ & $-50 \%$ & & & $+50 \%$ & $-50 \%$ & $+100 \%$ & $-100 \%$ \\
\hline \multicolumn{12}{|l|}{ Water $(\mathrm{mm} / \mathrm{yr})$} \\
\hline Evaporation & 180 & 187 & 147 & 190 & 147 & 163 & 193 & 197 & 148 & 180 & 180 \\
\hline Runoff and drainage & 170 & 269 & 101 & 161 & 201 & 412 & 247 & 95 & 260 & 170 & 170 \\
\hline \multicolumn{12}{|c|}{ Gross primary production of dry biomass $\left(\mathrm{g} \cdot \mathrm{m}^{-2} \cdot \mathrm{yr}^{-1}\right)$} \\
\hline $\begin{array}{l}\text { Respiration (vascular and } \\
\text { moss) }\end{array}$ & 116 & 170 & 74 & 119 & 106 & 122 & 115 & 113 & 118 & 117 & 114 \\
\hline \multicolumn{12}{|l|}{ Net primary production } \\
\hline tiont & 99 & 139 & 51 & 103 & 77 & 96 & 98 & 96 & 99 & 106 & 87 \\
\hline Net moss production & 117 & 116 & 115 & 117 & 91 & 119 & 118 & 117 & 117 & 118 & 116 \\
\hline Decomposition & 95 & 138 & 66 & 97 & 93 & 91 & 95 & 122 & 55 & 178 & 0 \\
\hline Net ecosystem production & 120 & 118 & 100 & 123 & 75 & 124 & 122 & 90 & 101 & 46 & 203 \\
\hline \multicolumn{12}{|l|}{ Nitrogen $\left(\mathrm{g} \cdot \mathrm{m}^{-2} \cdot \mathrm{yr}^{-1}\right)$} \\
\hline Mineralization & 1.85 & 2.67 & 1.27 & 1.87 & 1.80 & 1.77 & 1.83 & 2.37 & 1.06 & 3.45 & 0 \\
\hline Vascular-plant uptake & 1.0 & 1.77 & 0.49 & 1.06 & 0.79 & 0.86 & 0.96 & 0.84 & 1.11 & 1.14 & 0.41 \\
\hline Moss uptake & 0.10 & 0.10 & 0.10 & 0.10 & 0.10 & 0.12 & 0.11 & 0.10 & 0.10 & 0.10 & 0.10 \\
\hline Drainage loss & 0.02 & 0.03 & 0.01 & 0.02 & 0.02 & 0.05 & 0.03 & 0.01 & 0.03 & 0.02 & 0.02 \\
\hline
\end{tabular}

* Species present are: Ledum palustre, Vaccinium uliginosum, Vaccinium vitis-idaea, Carex bigelowii, Eriophorum vaginatum, Betula nana.

$\dagger$ Includes leaf, stem, and root production.

sensitive to external environmental factors, such as increased temperature, than to internal ecosystem variables.

Incoming solar irradiance was varied by +20 and $-50 \%$ (Table 16). Increasing solar irradiance by $20 \%$ increased evaporation and decreased drainage. Leaf productivity increased by only $4 \%$; moss production was unchanged. Net ecosystem production increased by $3 \%$. Mineralized nitrogen increased $\approx 1 \%$; nitrogen uptake increased $\approx 6 \%$. Drainage loss of nitrogen was unchanged. Decreasing solar irradiance by $50 \%$ decreased all the variables responding except drainage, which increased, and nitrogen taken up by mosses and lost through drainage, which were unchanged. Net ecosystem production was reduced by $37 \%$. ARTUS indicates that solar irradiance may be a limiting factor in tussock tundra ecosystems.

Precipitation was changed by increasing the probablity of rain on a given day by $100 \%$, i.e., the frequency of storms and fog, and by increasing the amount of rain on a rainy day by $50 \%$, i.e., more intense storms (Table 16). Increasing the probability of rainy days had greater effects than increasing the amount of precipitation per day. With increased probability of rain, precipitation for the summer season increased from 245 to $512 \mathrm{~mm}$. Evapotranspiration decreased and drainage of water increased to $412 \mathrm{~mm} / \mathrm{yr}$. Net vascular plant production went down slightly, and moss production increased slightly; net ecosystem production increased by only $3 \%$. The amount of nitrogen min- eralized decreased as did vascular-plant uptake of nitrogen. Uptake of nitrogen by mosses increased but not enough to offset the decrease in uptake by vascular plants. Nitrogen lost through drainage was $250 \%$ of the standard-case value. Increasing the amount of rain on a rainy day, without changing the frequency of rainy days, increased precipitation to $357 \mathrm{~mm}$, evaporation by $13 \mathrm{~mm}$, and drainage by $77 \mathrm{~mm}$; solar irradiance decreased slightly. Decreases in vascular plant and moss production and net ecosystem production were similar to decreases when the probability of rain was altered; however, vascular-plant uptake of nitrogen was not decreased as much, and nitrogen loss through drainage was $150 \%$ of the standard case. Changing the precipitation regimes affects processes largely through its effects on solar irradiance and soil temperature.

\section{Sensitivity to changes in soil variables}

The initial thickness of the organic layer was varied by $\pm 50 \%$ (Table 16 ). With an increase in organic thickness, net ecosystem production decreased by $25 \%$. More nitrogen was made available through increased mineralization, but vascular plants did not increase their uptake of nitrogen because their roots were in layers of the soil that did not thaw. Compared to increasing organic thickness, decreasing initial organic thickness had an opposite effect on all responding variables. The changes were of a greater magnitude when initial organic thickness was reduced; the most sensitive response was in drainage, which increased $53 \%$. 
TABLE 17. Results of the sensitivity analysis of the effect of changes in species properties on ecosystem processes involving water, carbon, and nitrogen.

\begin{tabular}{|c|c|c|c|c|c|c|c|}
\hline \multirow[b]{2}{*}{ Variable responding } & \multirow{2}{*}{$\begin{array}{l}\text { Standard } \\
\text { case }\end{array}$} & \multicolumn{2}{|c|}{$\begin{array}{l}\text { Nutrient uptake } \\
\text { adjustment factor }\end{array}$} & \multicolumn{2}{|c|}{ Initial biomass } & \multicolumn{2}{|c|}{$\begin{array}{l}\mathrm{N} \text { content of } \\
\text { new biomass }\end{array}$} \\
\hline & & $+100 \%$ & $-100 \% *$ & $+50 \%$ & $-50 \%$ & $+50 \%$ & $-50 \%$ \\
\hline \multicolumn{8}{|l|}{ Water (mm/yr) } \\
\hline Evaporation & 180 & 180 & 180 & 180 & 180 & 180 & 180 \\
\hline Runoff and drainage & 170 & 170 & 170 & 170 & 170 & 170 & 170 \\
\hline \multicolumn{8}{|c|}{ Gross primary production of dry biomass $\left(\mathrm{g} \cdot \mathrm{m}^{-2} \cdot \mathrm{yr}^{-1}\right)$} \\
\hline Respiration (vascular and moss) & 116 & 118 & 113 & 133 & 97 & 112 & 116 \\
\hline Net primary production & & & & & & & \\
\hline Net vascular-plant production $\dagger$ & 99 & 107 & 87 & 89 & 105 & 85 & 110 \\
\hline Net moss production & 117 & 117 & 119 & 114 & 114 & 117 & 118 \\
\hline Decomposition & 95 & 95 & 95 & 95 & 95 & 95 & 95 \\
\hline Net ecosystem production & 120 & 128 & 110 & 107 & 124 & 107 & 132 \\
\hline \multicolumn{8}{|l|}{ Nitrogen $\left(\mathrm{g} \cdot \mathrm{m}^{-2} \cdot \mathrm{yr}^{-1}\right)$} \\
\hline Mineralization & 1.85 & 1.85 & 1.85 & 1.85 & 1.85 & 1.85 & 1.85 \\
\hline Vascular-plant uptake & 1.0 & 1.79 & 0 & 0.88 & 1.03 & 0.85 & 1.13 \\
\hline Moss uptake & 0.10 & 0.10 & 0.12 & 0.12 & 0.08 & 0.10 & 0.10 \\
\hline Drainage loss & 0.02 & 0.02 & 0.02 & 0.02 & 0.02 & 0.02 & 0.02 \\
\hline
\end{tabular}

* A value of 0.0001 was used to simulate the elimination of mycorrhizal uptake without producing the errors that would be caused by dividing by zero.

† Includes leaf, stem, and root production.

Mineralization was changed from the standard case by reducing it to zero or doubling it (Table 16). Doubling mineralization increased net vascular plant production by only $7 \%$ but increased decomposition by $87 \%$ and reduced net ecosystem production by $62 \%$. Without mineralization, vascular plant production was reduced by $12 \%$; decomposition was reduced to zero, and net ecosystem production increased by $69 \%$. In ARTUS net ecosystem production has a strong inverse relationship to decomposition.

\section{Sensitivity to changes in species variables}

The uptake adjustment factor, which was used to simulate mycorrhizal uptake, was doubled or reduced to 0.0001 (Table 17). Doubling the uptake adjustment factor increased net vascular production by $8 \%$. Nitrogen uptake increased by $79 \%$, while drainage loss was unaffected. Nitrogen content increased in all species except Vaccinium vitis-idaea, in which it was unchanged. Moss production was unchanged. Net ecosystem production increased by $7 \%$. Using a value only slightly larger than zero, which eliminated mycorrhizal uptake without producing errors caused by dividing by zero, reduced vascular plant production by $12 \%$ and net primary production by $5 \%$. Without competition for nitrogen by the vascular plants, moss nitrogen uptake increased by $20 \%$.

The initial biomasses for leaves, stems, and roots were varied by $\pm 50 \%$ (Table 17). Increasing initial biomasses increased respiration by $15 \%$ and decreased vascular plant, moss, and net ecosystem production and the amount of nitrogen taken up by vascular plants. The uptake of nitrogen by moss increased because increased litterfall provided a large source of nitrogen made available to mosses by leaching. When the initial biomasses were reduced by $50 \%$, respiration decreased by $16 \%$, but net ecosystem production increased by only $3 \%$. Litter production was reduced $46 \%$, and less nitrogen was available to the mosses by leaching.

The nitrogen content of new biomass was varied by $\pm 50 \%$. Increasing the nitrogen required for new growth decreased net vascular-plant production by $14 \%$; decreasing the required nitrogen increased production by $11 \%$. Moss production was unaffected.

In ARTUS changing photosynthesis by $\pm 50 \%$ had very little effect on the responding variables. Respiration changed by $<1 \%$. Net vascular plant production increased $6 \%$ with increased photosynthesis but decreased only $2 \%$ with decreased photosynthesis. Decomposition and moss production were not affected. Net ecosystem production reflected the change in vascular plant production and increased $6 \%$ with a $50 \%$ increase in photosynthesis and decreased $2 \%$ with a $50 \%$ decrease. Increased and decreased respiration only affected net ecosystem production by $\approx 4 \%$. ARTUS indicates that carbon is not a limiting factor in tussock tundra. In the 26 sensitivity analyses done using ARTUS, the responding variables were least sensitive to a 50\% reduction in photosynthesis and third least sensitive to a $50 \%$ increase in photosynthesis.

Changing the potential maximum rate of growth of leaves, stems, and roots by $+50 \%$ increased net vascular plant production by $9 \%$; a decrease of $50 \%$ decreased production by $13 \%$. Moss production was not affected. Roots showed a greater response than leaves or stems, because in ARTUS roots have first priority on available resources. The response of a species depended on its innate maximum growth rate, as affected by carbohydrate or nitrogen limitation, and on the tim- 
TABle 17. Continued.

\begin{tabular}{|c|c|c|c|c|c|c|c|c|c|}
\hline \multicolumn{2}{|c|}{$\begin{array}{c}\text { N content at tissue } \\
\text { death }\end{array}$} & \multicolumn{2}{|c|}{ Photosynthesis } & \multicolumn{2}{|c|}{ Respiration } & \multicolumn{2}{|c|}{$\begin{array}{l}\text { Maximum } \\
\text { growth rate }\end{array}$} & \multicolumn{2}{|c|}{ Shoot density } \\
\hline$+50 \%$ & $-50 \%$ & $+50 \%$ & $-50 \%$ & $+50 \%$ & $-50 \%$ & $+50 \%$ & $-50 \%$ & $+100 \%$ & $+300 \%$ \\
\hline $\begin{array}{l}180 \\
170\end{array}$ & $\begin{array}{l}180 \\
170\end{array}$ & $\begin{array}{l}180 \\
170\end{array}$ & $\begin{array}{l}180 \\
170\end{array}$ & $\begin{array}{l}180 \\
170\end{array}$ & $\begin{array}{l}180 \\
170\end{array}$ & $\begin{array}{l}180 \\
170\end{array}$ & $\begin{array}{l}180 \\
170\end{array}$ & $\begin{array}{l}180 \\
170\end{array}$ & $\begin{array}{l}180 \\
170\end{array}$ \\
\hline 93 & 118 & 117 & 115 & 162 & 69 & 124 & 105 & 205 & 380 \\
\hline $\begin{array}{r}53 \\
117 \\
95 \\
75\end{array}$ & $\begin{array}{r}107 \\
117 \\
95 \\
128\end{array}$ & $\begin{array}{r}105 \\
117 \\
95 \\
127\end{array}$ & $\begin{array}{r}97 \\
117 \\
95 \\
118\end{array}$ & $\begin{array}{r}96 \\
117 \\
95 \\
117\end{array}$ & $\begin{array}{r}104 \\
117 \\
95 \\
125\end{array}$ & $\begin{array}{r}108 \\
117 \\
95 \\
130\end{array}$ & $\begin{array}{r}86 \\
117 \\
95 \\
108\end{array}$ & $\begin{array}{r}185 \\
103 \\
95 \\
192\end{array}$ & $\begin{array}{r}357 \\
33 \\
95 \\
294\end{array}$ \\
\hline $\begin{array}{l}1.85 \\
0.51 \\
0.10 \\
0.02\end{array}$ & $\begin{array}{l}1.85 \\
1.08 \\
0.10 \\
0.02\end{array}$ & $\begin{array}{l}1.85 \\
1.07 \\
0.10 \\
0.02\end{array}$ & $\begin{array}{l}1.85 \\
0.90 \\
0.10 \\
0.02\end{array}$ & $\begin{array}{l}1.85 \\
0.91 \\
0.10 \\
0.02\end{array}$ & $\begin{array}{l}1.85 \\
1.05 \\
0.10 \\
0.02\end{array}$ & $\begin{array}{l}1.85 \\
0.98 \\
0.10 \\
0.02\end{array}$ & $\begin{array}{l}1.85 \\
0.88 \\
0.10 \\
0.02\end{array}$ & $\begin{array}{l}1.85 \\
1.55 \\
0.17 \\
0.02\end{array}$ & $\begin{array}{l}1.85 \\
2.10 \\
0.31 \\
0.02\end{array}$ \\
\hline
\end{tabular}

ing of root and leaf growth in that species. The response of changing potential maximum rate of growth indicated that in ARTUS growth is limited by the availability of resources and not by the innate maximum growth rate of the individual species.

The density of growing points was increased by $100 \%$ and by $300 \%$ (Table 17). Increasing growing-point density increased net vascular plant production, net ecosystem production, and the amount of nitrogen taken up by both vascular plants and mosses. Moss production decreased, probably due to decreased irradiance at the moss surfaces because of shading by vascular plants.

Evaporation, drainage, decomposition, mineralized nitrogen, and drainage loss of nitrogen responded to changes in climatic and soil variables but were unaffected by changes in species variables. In ARTUS the plant community did not affect soil temperatures and therefore did not affect evaporation and drainage. Decomposition, mineralized nitrogen, and drainage loss of nitrogen in ARTUS are controlled by climatic variables; therefore, changes in species variables did not change them from the standard case values.

Ranking of the relative sensitivities of climatic, soil, and species variables used in the sensitivity analysis of ARTUS indicates that the model is more sensitive to climatic and soil variables than to species variables (Table 18). The tussock tundra system as encoded in ARTUS was most sensitive to $\pm 4^{\circ} \mathrm{C}$ air temperature changes, decreased solar irradiance, and changes in the initial organic thickness that altered the seasonal depth of thaw.

The strong effect of increased shoot density on the responding variables is an artifact of the model structure because most variables are calculated on the basis of the number of shoots per square metre. If the effect of shoot density is discounted, the only species variable ranked in the top 11 variables is increased nitrogen content at leaf death. The tussock tundra system may be nitrogen limited because increasing the required levels of nitrogen in plant tissues eliminated growth in a number of species. The model is more sensitive to changes in respiration than to changes in photosynthesis, but ARTUS is not sensitive to variables affecting carbon accumulation.

Several simplifications, such as the treatment of photosynthesis and respiration, were included in ARTUS; some of these could be improved. The data on photosynthetic rate of vascular plants indicate a high level of physiological plasticity and ecotypic differentiation that must be taken into account to predict carbon balance across large environmental gradients. The maximal photosynthetic rates used in ARTUS (Table 4) were from a single data set that was collected under similar measurement conditions using the same technique (Bigger and Oechel 1982). These data allow comparison of species differences but do not accommodate the variability found in nature.

The ability to predict photosynthesis and respiration at a given site or to generalize over larger areas in the Arctic is limited by several factors. While acclimation has been well demonstrated in the literature, the basis for its quantitative prediction in nature is not in hand. Second, data on photosynthesis in the Arctic are insufficient to assess quantitatively the nature and extent of local variability in patterns and rates or the extent of ecotypic differentiation throughout the Arctic. Third, few data are available on whole-plant carbon balance, including root and stem respiration rates. Other functional relationships in the carbon balance need to be developed experimentally and included in ARTUS. These include the feedback of carbohydrate reserves on rates of photosynthesis and respiration and the response of photosynthesis and respiration to various 
TABLE 18. Ranking of the mean relation sensitivity of climatic (C), soil (S), and species (P) variables used in the ARTUS sensitivity runs.

\begin{tabular}{|c|c|c|}
\hline Rank & Variable & $\begin{array}{c}\bar{x} \text { rela- } \\
\text { tive } \\
\text { sensi- } \\
\text { tivity }\end{array}$ \\
\hline 1 & Temperature $+4^{\circ} \mathrm{C}(\mathrm{C})$ & 80.3 \\
\hline 2 & Solar $-20 \%(C)$ & 52.9 \\
\hline 3 & Temperature $-4^{\circ} \mathrm{C}(\mathrm{C})$ & 49.7 \\
\hline 4 & Initial organic thickness $-50 \%(\mathrm{C})$ & 39.5 \\
\hline 5 & Shoot density $+100 \%(\mathrm{P})$ & 38.5 \\
\hline 6 & Shoot density $+300 \%(\mathrm{P})$ & 36.3 \\
\hline 7 & Initial organic thickness $+50 \%(\mathrm{C})$ & 31.5 \\
\hline 8 & $\mathrm{~N}$ content at death $+50 \%(\mathrm{C})$ & 27.7 \\
\hline 9 & Solar $+20 \%(C)$ & 27.4 \\
\hline 10 & Precipitation probability $+100 \%(\mathrm{C})$ & 27.3 \\
\hline 11 & Mineralization $+100 \%$ (S) & 21.1 \\
\hline 12 & Mineralization $-100 \%$ (S) & 18.9 \\
\hline 13 & Precipitation amount $+50 \%(\mathrm{C})$ & 18.2 \\
\hline 14 & Initial biomass $+50 \%(\mathrm{P})$ & 16.9 \\
\hline 15 & Initial biomass $-50 \%(\mathrm{P})$ & 16.0 \\
\hline 16 & Respiration $+50 \%(\mathrm{P})$ & 14.1 \\
\hline 17 & Respiration $-50 \%(\mathrm{P})$ & 9.5 \\
\hline 18 & $\begin{array}{l}\text { Nutrient uptake adjustment factor } \\
+100 \%(\mathrm{P})\end{array}$ & 8.6 \\
\hline 19 & $\mathrm{~N}$ content new biomass $-50 \%(\mathrm{P})$ & 7.6 \\
\hline 20 & Maximum growth rate $+50 \%(\mathrm{P})$ & 7.3 \\
\hline 21 & $\mathrm{~N}$ content new biomass $+50 \%(\mathrm{P})$ & 7.1 \\
\hline 22 & $\mathrm{~N}$ content at death $-50 \%(\mathrm{P})$ & 5.2 \\
\hline 23 & Maximum growth rate $-50 \%(\mathrm{P})$ & 4.9 \\
\hline 24 & Photosynthesis $+50 \%(\mathrm{P})$ & 4.3 \\
\hline 25 & $\begin{array}{l}\text { Nutrient uptake adjustment factor } \\
-100 \%(\mathrm{P})\end{array}$ & 3.8 \\
\hline 26 & Photosynthesis $-50 \%(\mathrm{P})$ & 1.9 \\
\hline
\end{tabular}

nutrient conditions, particularly the relation between nitrogen content and photosynthetic rate. The following relationships for mosses should also be added to ARTUS. (1) Politrichaceous mosses can probably take up nutrients from the soil and transport these nutrients through their axes. They may have access to a nutrient pool not available to other mosses nor to many vascular species. (2) Mosses support nitrogen fixation at rates which depend upon species' light and moisture levels.

The rate of decomposition is probably oversimplified in ARTUS. The assumptions of uniform biochemical composition of organic material, lack of oxygen tension limitations, lack of enzyme activity below $0^{\circ} \mathrm{C}$, omission of the lignin and lignocellulose components that constitute $5-38 \%$ of the plant structural material (Heal et al. 1981), and omission of the dynamics of lignin and lignocellulose degradation all contribute to oversimplified estimations of decomposition. Even though these limitations exist in ARTUS, addressing the functional components of decomposition and the factors regulating them gives insight into the stability and responsiveness of decomposition in tussock tundra soils.

Most of the processes involved in nitrogen and phosphorus cycling are not well established for tussock tundra, particularly soil equilibrium reactions and the ecosystem input and output values.
Although microclimatological data have been measured at Eagle Creek for three summers and standard screen temperatures have been measured for several additional years, adequate climatological information, including irradiance and soil surface temperature, is almost nonexistent for other locations in northern Alaska (Haugen and Brown 1978). This lack of basic data seriously weakens the extensive validations and extrapolations of ARTUS in the broader arctic context.

\section{IMPLICATIONS OF RESEARCH FINDINGS AND ARTUS SIMULATIONS FOR MANAGEMENT AND UNDERSTANDING TUNDRA ECOLOGY}

In tussock tundra ecological and biological processes are closely controlled by nutrient limitations, primarily of nitrogen and phosphorus. Nutrient limitations are in delicate balance with site water and heat balance because of the influences of water and heat on the growth of mosses and the sequestering of nutrients in dead moss organic matter. In spite of nutrient limitations and controls by water and heat, field experiments indicate that carbon is often limiting to ecosystem function. Any loss in the ability to incorporate carbon is detrimental to plant growth and survival and to decomposition and mineralization.

By far the major source of nutrients is from decomposition and mineralization of organic nutrients. Any loss of organic material from the site or alteration of the organic material induces major changes in production and often in species composition. Frequent fertilization increases the growth of graminoids and decreases the abundance of evergreen shrubs. The effect of losses of nutrients in organic material may persist because of the slow rate of nutrient accumulation in the tussock tundra ecosystem.

Nutrient availability appears to be relatively high in the surface organic layer, because of higher rates of decomposition and mineralization, and at the freezethaw interface, because of the physical disruption of the organic matter and release of inorganic nutrients by the freeze-thaw action.

Mycorrhizae are unquestionably important in the uptake of nutrients by vascular plants. Disruption of the soil environment to the detriment of mycorrhizae disrupts the nutrient balance of vascular plant species. Mycorrhizae are reduced or eliminated by waterlogging and oil spills.

The site water balance affects the production and decomposition of the organic matter. The growth rates of moss depend mostly on the water balance of the site. Moss growth acts as a mechanism adjusting the resistance between the soil water and the evaporating surface, so the moss water content at the evaporating surface remains within relatively narrow limits.

The prinicpal rate regulators are moisture and temperature, as they govern production, decomposition, and nutrient cycling. In tundra soils these processes are for the most part carried out in the upper part of the 
thin, seasonally thawed or active layer, half or more of which is composed of organic materials. The stability of the active later is governed by the stability of the underlying ice-rich permanently frozen materials, which in turn depend upon the physical integrity of the organic part of the active layer. One of the major ecological and engineering problems facing land use planners in tundra regions is minimizing disruption of the active layer. There is often a need to predict the course of events set in motion when the stability of the active layer is disrupted.

A major control of the depth of thaw in the active layer is the ice content of the soil. Excluding the formation of ice lenses and ice wedges, the ice content varies greatly between organic and mineral soils. Removal of the organic mat decreases the water storage capacity. The heat used for melting ice in the soil layer is reduced, and the soil thaws more deeply. Dry organic material acts as an insulator preventing thaw. Waterlogged organic material is slow to thaw because of its high ice content.

Major disturbances to the organic mat, which is usually formed by Sphagnum sp., C. bigelowii, and $E$. vaginatum, are the result of compression rather than fertilization, impoundment, or oil spill. Compression affects thermal and moisture conduction within the active layer. Some results of the disturbance are immediately apparent and can be transitory, while others are subtle, additive, long-lasting, and in some cases irreversible.

The predictive capabilities of ARTUS are only now being tested, and caution should be used in basing scientific and management decisions on model simulations. However, ARTUS should be able to identify and quantify the interactions of the tundra plant-soil system to the extent that it can predict the magnitude and direction of plant responses to changes in state variables. Using ARTUS in conjunction with mapped, regional geobotanical units such as those delineated by Walker et al. (1980), planners who are considering alternatives for tussock tundra areas would have the tools for enlightened site selection and the ability to predict the consequences of alternative land use decisions. The model can be used to understand the effect of local, intermittent impoundments and local, incomplete drainage interruptions caused by the construction of roads and building pads. ARTUS should be able to predict the effect of oil spills, either as a spray or surface flow, that occur in wet or moist tundra. Such a perturbation may totally eliminate some species, may have no effect on others, and might even increase biomass production in some. Although the effect of salt water spills in wet and moist tundra has not been considered by this research, ARTUS should be able to predict the effects of such a perturbation that should eliminate shallow-rooted, woody vegetation and decrease biomass production in all species except graminoids. Salt water may also increase soil temperature and the depth of thaw. The model should also aid in predicting the effects of fertilization of tundra ecosystems, which include the selection of graminoids over evergreen shrubs, increased mineralization, increased decomposition, increased moss cover, and increased biomass production. ARTUS should be of assistance in assessing long-term regional environmental problems such as the effects of road dust, which has a graded influence for a distance of up to $5 \mathrm{~km}$ from the road.

It is still unclear how far the tundra ecosystem can be perturbed and still recover. Irreversible changes are apparent within a few years when the permafrost or the organic mat are altered severely. Moderate changes are apparent after $10 \mathrm{yr}$, even though the perturbations themselves are no longer visible. Because of the lack of precision in current field and laboratory measurements, it is difficult to determine whether the ecosystem is returning to a stable state or degenerating after moderate impacts. The challenge of developing a simulation model increases the need among investigators for accurate and precise measurements. The model also defines gaps in existing knowledge of how the tundra ecosystem functions. With a broadened and improved data base, the model can provide an objective framework to project current conditions into the future.

\section{ACKNOWLEDGMENTS}

This study has been supported by the Department of Energy, Office of Health and Environmental Research, Office of Environment on contract DE-AC03-77EV01525. We thank Rhonda Watson, Beth Sigren, Marti Poole, Penny Rafter, and Chris Miller for their help in preparing the manuscript and Dr. George Cox and Dr. William H. Schlesinger for their helpful editorial suggestions. This manuscript was completed after the death of Dr. Phil Miller. It is dedicated to his efforts to pursue ecosystem studies and ecosystem modelling in tundra and chapparal.

\section{Literature Cited}

Allan, R. J., J. Brown, and S. Rieger. 1969. Poorly drained soils with permafrost in interior Alaska. Soil Science Society of America Proceedings 33:599-605.

Alpert, P., and W. C. Oechel. 1982. Bryophyte distribution, water relations, and ecology in Alaskan tussock tundra. Holarctic Ecology 5:99-108.

Alpert, P., and W. C. Oechel. 1984, in press. Microdistribution and water loss resistances of selected bryophytes in an Alaskan Eriophorum tussock tundra. Holarctic Ecology.

Babb, T. A., and L. C. Bliss. 1974. Susceptibility to environmental impact in the Queen Elizabeth Islands. Arctic 27:234-236.

Barel, D., and R. J. Barsdate. 1978. Phosphorus dynamics of wet coastal tundra soils near Barrow, Alaska. Pages 516537 in D. C. Adriano and I. L. Brisbin, Jr., editors. Environmental chemistry and cycling processes. Symposium Series CONF-760429, United States Department of Energy, National Technical Information Service, Springfield, Virginia, USA.

Barkley, S. A., D. Barel, W. A. Stoner, and P. C. Miller. 1978. Controls on decomposition and mineral release in wet meadow tundra simulation approach. Pages 754-778 in D. C. Adriano and I. L. Brisbin, Jr., editors. Environmental chemistry and cycling processes. Symposium Series CONF760429 , United States Department of Energy, National Technical Information Service, Springfield, Virginia, USA.

Bigger, C. M., and W. C. Oechel. 1982. Nutrient effect on maximum photosynthesis in arctic plants. Holarctic Ecology 5:158-163. 
Billings, W. D., P. J. Godfrey, B. F. Chabot, and D. P. Bourque. 1971. Metabolic acclimation to temperature in arctic and alpine ecotypes of Oxyria digyna. Arctic and Alpine Research 3:277-289.

Billings, W. D., J. O. Luken, D. A. Mortensen, and K. M. Peterson. 1982. Arctic tundra: a source or sink for atmospheric carbon dioxide in a changing environment. Oecologia (Berlin) 53:7-11.

Bliss, L. C., editor. 1977. Truelove Lowland, Devon Island, Canada: a high arctic ecosystem. University of Alberta Press, Edmonton, Alberta, Canada.

Brown, J., P. C. Miller, L. L. Tieszen, and F. L. Bunnell, editors. 1980. An arctic ecosystem: the coastal tundra at Barrow, Alaska. Dowden, Hutchinson and Ross, Stroudsburg, Pennsylvania, USA.

Brunt, D. 1932. Notes on radiation in the atmosphere. International Quarterly Journal of the Royal Meteorological Society 58:389-420.

Bunnell, F. L., S. F. MacLean, and J. Brown. 1975. Barrow, Alaska, U.S.A. In T. Rosswall and O. W. Heal, editors. Structure and function of tundra ecosystems. Ecological Bulletins.-NFR 20:73-124.

Burns, R. G. 1978. Soil enzymes. Academic Press, New York, New York, USA.

Challinor, J. L., and P. L. Gersper. 1975. Vehicle perturbation effects upon soil-plants. I. Effects on the chemical regimes. Soil Science Society of America Proceedings 39: 689-695.

Chapin, F. S., III, R. S. Barsdate, and D. Barel. 1978. Phosphorus cycling in Alaskan coastal tundra: a hypothesis for the regulation of nutrient cycling. Oikos 31:189-199.

Chapin, F. S., III, and A. Bloom. 1976. Phosphate absorption: adaptations of tundra graminoids to a low temperature, low phosphorus environment. Oikos 27:111-121.

Chapin, F. S., III, D. A. Johnson, and J. D. McKendrick. 1980. Seasonal movement of nutrients in plants of differing growth form in an Alaskan tundra ecosystem: implications for herbivory. Journal of Ecology 68:168-209.

Chapin, F. S., III, and G. R. Shaver. 1981. Changes in soil properties and vegetation following disturbance of Alaskan arctic vegetation. Journal of Applied Ecology 18:605-617.

Chapin, F. S., III, and M. Slack. 1979. Effect of defoliation upon root growth, phosphate absorption and respiration in nutrient limited tundra graminoids. Oecologia (Berlin) 42 : 67-79.

Chapin, F. S., III, and P. R. Tryon. 1982. Phosphate absorption and root respiration of different plant growth forms from northern Alaska. Holarctic Ecology 5:164-171.

Chapin, F. S., III, and K. Van Cleve. 1978. Nitrogen and phosphorus distribution in an Alaskan tussock tundra ecosystem: natural patterns and implications for development. Pages 738-753 in D. C. Adriano and I. L. Brisbin, editors. Environmental chemistry and cycling processes. Symposium Series CONF-760429, United States Department of Energy, National Technical Information Service, Springfield, Virginia, USA.

Chapin, F. S., III, K. Van Cleve, and M. C. Chapin. 1979. Soil temperature and nutrient cycling in the tussock growth form of Eriophorum vaginatum L. Journal of Ecology 67: 169-189.

Dingman, S. L., R. G. Barry, G. Weller, C. Benson, E. F. LeDrew, and C. W. Goodwin. 1980. Climate, snow cover, microclimate, and hydrology. Pages 30-65 in J. Brown, P. C. Miller, L. L. Tieszen, and F. L. Bunnell, editors. An arctic ecosystem: the coastal tundra at Barrow, Alaska. Dowden, Hutchinson, and Ross, Stroudsburg, Pennsylvania, USA.

Ellis, S. 1980. An investigation of weathering in some arcticalpine soils on the northeast flank of Oksskolten, North Norway. Journal of Soil Science 31:371-385.
Eriksson, K. E. 1978. Enzyme mechanisms involved in cellulose hydrolysis by the root fungus Sporutrichum pulverulentum. Biotechnical Review 20:317-332.

Everett, K. R. 1973. Evolution of the soil landscape in the sand region of the arctic coastal plain as exemplified at Atkasook, Alaska. Arctic and Alpine Research 32:207-223.

Everett, K. R. 1981. Soil landscapes at selected sites along environmental gradients in northern Alaska. Department of the Army, Research Triangle Park, North Carolina, USA.

Fetcher, N., and G. R. Shaver. 1983. Life histories of tillers of Eriophorum vaginatum in relation to tundra disturbance. Journal of Ecology 71:131-147.

Flint, P. S., and P. L. Gersper. 1974. Nitrogen nutrient levels in arctic tundra soils. Pages 375-387 in A. J. Holding, O. W. Heal, S. F. MacLean, Jr., and P. W. Flanigan, editors. Soil organisms and decomposition in tundra. Tundra Biome Steering Committee, Stockholm, Sweden.

Gersper, P. L. 1972. Chemical and physical soil properties and their seasonal dynamics at the Barrow intensive site. Pages 87-93 in S. Bowen, editor. Proceedings of the 1972 Tundra Biome Symposium, Lake Wilderness Center, University of Washington, July 1972. United States Tundra Biome, Cold Regions Research and Engineering Laboratory, Hanover, New Hampshire, USA.

Gersper, P. L., V. Alexander, S. A. Barkley, R. J. Barsdate, and P. S. Flint. 1980. The soils and their nutrients. Pages 219-254 in J. Brown, P. C. Miller, L. L. Tieszen, and F. L. Bunnell, editors. An arctic ecosystem: the coastal tundra at Barrow, Alaska. Dowden, Hutchinson, and Ross, Stroudsburg, Pennsylvania, USA.

Gilardi, J. 1984. Plant growth and phenological development as related to thermal environment in north slope Alaska. Thesis. San Diego State University, San Diego, California, USA.

Gosink, T. A., and J. J. Kelly. 1979. Carbon monoxide evolution from arctic surfaces during spring thaw. Journal of Geophysical Research 84:C 11, 7041.

Haag, R. W., and L. C. Bliss. 1974. Energy budget changes following surface disturbance to upland tundra. Journal of Applied Ecology 11:355-374.

Hackett, W. F., W. J. Connors, T. K. Kirk, and J. G. Zeikus. 1977. Microbial decomposition of synthetic ${ }^{14} \mathrm{C}$-labelled lignins in nature: lignin biodegradation in a variety of natural materials. Applied Environmental Microbiology 33: 43-51.

Halsted, R. L., and R. B. McKercher. 1975. Biochemistry and cycling of phosphorus. Pages 31-63 in E. A. Paul and A. D. McLaren, editors. Soil biochemistry. Marcel Dekker, New York, New York, USA.

Haugen, R. K., and J. Brown. 1978. Climatic and dendroclimatic indices in the discontinuous permafrost zone of the central Alaskan uplands. Pages 392-398 in Proceedings of the Third International Conference on Permafrost. Volume 1. National Research Council of Canada, Ottawa, Ontario, Canada.

Heal, O. W., P. W. Flanagan, D. D. French, and S. F. MacLean, Jr. 1981. Decomposition and accumulation of organic matter in tundra. Pages 587-633 in L. C. Bliss, O. W. Heal, and J. J. Moore, editors. Tundra ecosystems: a comparative analysis. Cambridge University Press, Cambridge, England.

Hedges, A., and R. S. Wolfe. 1974. Extracellular enzymes from myxobacter AL-1 that exhibits both Bl-4 glucanase and chitosanase activities. Journal of Bacteriology 120:844853.

Herbein, S. A. 1981. Soil phosphatases: factors affecting enzyme activity in arctic tussock tundra and Virginia soils. Thesis. Biology Department, Virginia Polytechnic Institute and State University, Blacksburg, Virginia, USA.

Hicklenton, P. R., and W. C. Oechel. 1977. The influence 
of light intensity and temperature on the field carbon dioxide exchange rate of Dicranum fuscescens in the subarctic. Arctic and Alpine Research 9:407-419.

Hulten, E. 1968. Flora of Alaska and neighboring territories. Stanford University Press, Stanford, California, USA.

Johnson, D. A., and L. L. Tieszen. 1976. Aboveground biomass allocation, leaf growth, and photosynthesis pattern in tundra plant forms in arctic Alaska. Oecologia (Berlin) 24:159-173.

Kanda, T., D. Wakabayaski, and K. Nisizawa. 1976. Xylanase activity of an endocellulase of carboxymethyl-cellulase type from Irpex lactens. Journal of Biochemistry 79: 989-995.

Kirk, T. K., H. H. Yang, and P. Keyser. 1978. The chemistry and physiology of the fungal denaturation of lignin. Developments in Industrial Microbiology 19:51-61.

Kummerow, J., and W. Russell. 1980. Seasonal root growth in the arctic tussock tundra. Oecologia (Berlin) 47:196-199.

Lawrence, B. A., M. C. Lewis, and P. C. Miller. 1978. A simulation model of population processes of arctic tundra graminoids. Pages 599-619 in L. L. Tieszen, editor. Vegetation and production ecology of an Alaskan arctic tundra. Springer-Verlag, New York, New York, USA.

Likens, G. E., F. H. Bormann, R. S. Pierce, J. S. Eaton, and N. M. Johnson. 1977. Biogeochemistry of a forest ecosystem. Springer-Verlag, New York, New York, USA.

Limbach, W. E., W. C. Oechel, and W. Lowell. 1982. Photosynthetic and respiratory response to temperature and light of three Alaskan tundra growth forms. Holarctic Ecology 5:150-157.

Linkins, A. E. 1981. Cellulose hydrolysis in tussock tundra soils. Thirty-second Alaskan Science Conference. University of Alaska Publications, Fairbanks, Alaska, USA.

Linkins, A. E., and R. K. Antibus. 1978. Ectomycorrhizal fungi of Salix rotundifolia Trautv. II. Impact of surface applied Prudhoe crude oil on mycorrhizal root respiration and cold acclimation. Arctic 31:381-393.

Linkins, A. E., R. M. Atlas, and P. Gustin. 1978. Effect of surface applied crude oil on soil and vascular plant root respiration, soil cellulase, and aryl hydrocarbon hydroxylase at Barrow, Alaska. Arctic 31:355-365.

Linkins, A. E., J. M. Melillo, and R. L. Sinsabaugh. 1983. Regulation of cellulose hydrolysis in terrestrial and aquatic ecosystems. In C. A. Reddy and J. Tiege, editors. Proceedings of the Third International Symposium on Microbial Ecology. Ann Arbor Press, Ann Arbor, Michigan, USA.

Linkins, A. E., and J. L. Neal. 1982. Soil cellulase, chitinase, and protease activity in Eriophorum vaginatum tussock tundra at Eagle Summit, Alaska. Holarctic Ecology 5:135138.

Marion, G. M., J. Kummerow, and P. C. Miller. 1981. Predicting nitrogen mineralization in chaparral soils. Soil Science Society of America Journal 45:956-961.

Marion, G. M., and P. C. Miller. 1982. Nitrogen mineralization in a tussock tundra soil. Arctic and Alpine Research 14:287-293.

Marion, G. M., P. C. Miller, J. Kummerow, and W. C. Oechel. 1982. Competition for nitrogen in a tussock tundra ecosystem. Plant and Soil 66:317-327.

McCown, B. H. 1978. The interaction of organic nutrients, soil nitrogen and soil temperature on plant growth and survival in the arctic environment. Pages 435-456 in L. L. Tieszen, editor. Vegetation and production ecology of an Alaskan arctic tundra. Springer-Verlag, New York, New York, USA.

McKendrick, J. D., V. J. Ott, and G. A. Mitchell. 1978. Effect of nitrogen and phosphorus fertilization on carbohydrate and nutrient levels in Dupontia fisheri and Arctagrostis latifolia. Pages 509-537 in L. L. Tieszen, editor.
Vegetation and production ecology of an Alaskan arctic tundra. Springer-Verlag, New York, New York, USA.

McLaren, A. D. 1975. Soil as a system of humus and clay immobilization enzymes. Chemica Scripta 8:97-99.

Miller, O. K., Jr. 1982. Mycorrhizae, mycorrhizal fungi and fungal biomass in subalpine tundra at Eagle Summit, Alaska. Holarctic Ecology 5:125-134.

Miller, P. C. 1981. Carbon balance in northern ecosystems and the potential effects of carbon dioxide induced climatic change. Report of a workshop. San Diego, California, 7-9 March 1980. United States Department of Energy, Washington, D.C., USA.

- 1982. The availability and utilization of resources in tundra ecosystems. Holarctic Ecology 5:85-220.

Miller, P. C., R. Mangan, and J. Kummerow. 1982. Vertical distribution of organic matter in eight vegetation types near Eagle Summit, Alaska. Holarctic Ecology 5:117-124.

Miller, P. C., and W. A. Stoner. 1979. Canopy structure and environmental interactions. Pages 163-173 in D. Solbrig, S. Jain, G. B. Johnson, and P. H. Raven, editors. Plant population biology. Columbia University Press, New York, New York, USA.

Miller, P. C., W. A. Stoner, and L. L. Tieszen. 1976. A model of stand photosynthesis for the wet meadow tundra at Barrow, Alaska. Ecology 57:411-430.

Miller, P. C., W. A. Stoner, L. L. Tieszen, M. Allessio, B. McCown, F. S. Chapin, III, and G. Shaver. 1978. A model of carbohydrate, nitrogen, phosphorus allocation and growth in tundra production. Pages 577-598 in L. L. Tieszen, editor. Vegetation and production ecology of an Alaskan arctic tundra. Springer-Verlag, New York, New York, USA.

Miller, P. C., and L. L. Tieszen. 1972. A preliminary model of processes affecting primary production in the arctic tundra. Arctic and Alpine Research 4:1-18.

Miller, P. C., P. J. Webber, W. C. Oechel, and L. Tieszen. 1981. Biophysical processes and primary production. Pages 66-101 in J. Brown, P. C. Miller, L. L. Tieszen, and F. L. Bunnell, editors. An arctic ecosystem: the coastal tundra at Barrow, Alaska. Dowden, Hutchinson, and Ross, Stroudsburg, Pennsylvania, USA.

Morgan, J. M. 1976. A simulation model of the growth of the wheat plant. Dissertation. Macquarie University, Sydney, Australia.

Murray, F. W. 1967. On the computation of saturation vapor pressure. Journal of Applied Meteorology 6:203-204.

Murray, C., and P. C. Miller. 1982. Phenological observations of major plant growth forms and species in montane and Eriophorum vaginatum tussock tundra in central Alaska. Holarctic Ecology 5:109-116.

Nakano, N., and J. Brown. 1972. Mathematical modeling and validations of the thermal regimes in tundra soils, Barrow, Alaska. Arctic and Alpine Research 4:19-38.

Nye, P. H., and P. B. Tinker. 1977. Solute movement in the soil-plant system. University of California Press, Berkeley, California, USA.

Oberbauer, S., and P. C. Miller. 1979. Plant water relations in montane and tussock tundra vegetation types in Alaska. Arctic and Alpine Research 11:69-81.

Oberbauer, S., and P. C. Miller, 1981. Some aspects of plant water relations in Alaskan arctic tundra species. Arctic and Alpine Research 13:205-218.

Oberbauer, S., and P. C. Miller. 1982. Growth of Alaskan tundra plants in relation to water potential. Holarctic Ecology 5:194-199.

Oechel, W. C. 1976. Seasonal patterns of temperature response of $\mathrm{CO}_{2}$ flux and acclimation in arctic mosses growing in situ. Photosynthetica 10:447-456.

Oechel, W. C., and N. J. Collins. 1976. Comparative $\mathrm{CO}_{2}$ exchange patterns in mosses from the two tundra habitats 
at Barrow, Alaska. Canadian Journal of Botany 54:13551369.

Oechel, W. C., and B. Sveinbjornsson. 1978. Primary production processes in arctic bryophytes at Barrow, Alaska. Pages 269-298 in L. L. Tieszen, editor. Vegetation and production ecology of the Alaskan arctic tundra. SpringerVerlag, New York, New York, USA.

Pavlov, A. V. 1976. Heat transfer of the soil and atmosphere at northern and temperate altitudes. Draft Translation 511, Cold Regions Research and Engineering Laboratory, Hanover, New Hampshire, USA.

Penman, H. L. 1948. Natural evaporation from open water, bare soil and grass. Royal Society of London Proceedings (A) 193:120-145.

Polar Research Board. 1982. Arctic terrestrial environmental research programs of the Office of Energy Research, Department of Energy: evaluation and recommendations. National Academic Press, Washington, D.C., USA.

Poole, D. K., and P. C. Miller. 1982. Carbon dioxide flux from three arctic tundra types in north-central Alaska, U.S.A. Arctic and Alpine Research 14:27-32.

Reese, E. T. 1977. Degradation of polymorphic carbohydrates by microbial enzymes. Pages 311-367 in F. A. Loews and V. C. Runeckles, editors. The structure, biosynthesis, and degradation of wood. Plenum, New York, New York, USA.

Rinderknecht, H., M. C. Goekas, P. Silverman, and B. J. Havenback. 1968. A new ultrasensitive method for the determination of proteolytic activity. Clinical Chemistry Acta 21:197-203.

Ryden, B. E. 1981. Hydrology of northern tundra. Pages 115-139 in L. C. Bliss, O. W. Heal, and J. J. Moore, editors. Tundra ecosystems: a comparative analysis. International Biological Programme 25, Cambridge University Press, Cambridge, England.

Saebo, S. 1969. On the mechanism behind the effect of freezing and thawing on dissolved phosphorus in Sphagnum fuscum peat. Meldinger frä Norges Landbrukshogskole 48:1-10.

Shaver, G. R. 1981. Mineral nutrition and leaf longevity in an evergreen shrub Ledum palustre ssp. decumbens. Oecologia (Berlin) 49:362-365.

Shaver, G. R., and F. S. Chapin, III. 1980. Response to fertilization by various plant growth forms in an Alaskan tundra: nutrient accumulation and growth. Ecology 61:662675.

Shaver, G. R., and J. C. Cutler. 1979. The vertical distribution of live vascular phytomass in cotton grass tussock tundra. Arctic and Alpine Research 11:335-342.

Shvetsova, V. M., and V. L. Voznesensky. 1970. Diurnal and seasonal variations in the rate of photosynthesis in some plants of Western Taimyr. Botanichnye Zhurnal (Kiev) 55:66-76.

Sinsabaugh, R., E. F. Benfield, and A. E. Linkins. 1981. Cellulase activity associated with the decomposition of leaf litter in a woodland stream. Oikos 36:184-190.

Skre, O., and W. C. Oechel. 1979. Moss production in a black spruce Picea mariana forest with permafrost near Fairbanks, Alaska, as compared with two permafrost fire stands. Holarctic Ecology 2:245-254.

Skre, O., and W. C. Oechel. 1981. Moss functioning in different taiga ecosystems in interior Alaska. I. Seasonal, phenotypic, and drought effects on photosynthesis and response patterns. Oecologia (Berlin) 48:50-59.

Skre, O., W. C. Oechel, and P. M. Miller. 1983. Moss leaf water content and solar radiation at the moss surface in a mature black spruce forest in central Alaska. Canadian Journal of Forestry 13:860-868.

Smith, E. M., and E. B. Hadley. 1974. Photosynthetic and respiratory acclimation to temperature in Ledum groen- landicum populations. Arctic and Alpine Research 6:1327.

Sorensen, T. 1941. Temperature relations and phenology of the northeast Greenland flowering plants. Meddelelser om Gronland 125:1-305.

Spaulding, B. P. 1978. The effect of biocidal treatments on respiration and enzymatic activities of Douglas-fir needle litter. Soil Biology Biochemistry 10:537-543.

Stanford, G., and S. J. Smith. 1972. Nitrogen mineralization potential of soils. Soil Science Society of America Proceedings 36:465-472.

Stoner, W. A., P. C. Miller, and W. C. Oechel. 1978a. Simulation of the effect of the tundra vascular plant canopy on the productivity of four moss species. Pages 371-387 in L. L. Tieszen, editor. Vegetation and production ecology of an Alaskan arctic tundra. Springer-Verlag, New York, New York, USA.

Stoner, W. A., P. C. Miller, and L. L. Tieszen. 1978b. A model of plant growth and phosphorus allocation for $\mathrm{Du}$ pontia fisheri in coastal wet meadow tundra. Pages 559576 in L. L. Tieszen, editor. Vegetation and production ecology of an Alaskan arctic tundra. Springer-Verlag, New York, New York, USA.

Stoner, W. A., P. M. Miller, and P. C. Miller. 1982. Seasonal dynamics and standing crops of biomass and nutrients in a subarctic tundra vegetation. Holarctic Ecology 5:172-179.

Stuart, L., and P. C. Miller. 1982. Soil oxygen flux measured polarographically in an Alaskan tussock tundra. Holarctic Ecology 5:139-144.

Stuart, L., S. Oberbauer, and P. C. Miller. 1982. Evapotranspiration measurements in Eriophorum vaginatum tussock tundra in Alaska. Holarctic Ecology 5:145-149.

Sveinbjornsson, B., and W. C. Oechel. 1983. The effect of temperature preconditioning on the temperature sensitivity of net $\mathrm{CO}_{2}$ flux in geographically diverse populations of the moss Polytrichum commune. Ecology 64:1 100-1108.

Tabatabai, M. A., and J. M. Bremner. 1969. Use of p-nitrophenyl phosphate for assay of soil phosphatase activity. Soil Biology Biochemistry 1:301-307.

Tieszen, L. L. 1978. Photosynthesis in the principal Barrow, Alaska species: a summary of field and laboratory responses. Pages 241-268 in L. L. Tieszen, editor. Vegetation and production ecology of an Alaskan arctic tundra. Springer-Verlag, New York, New York, USA.

Van Cleve, K. 1974. Organic matter quality in relation to decomposition. Pages 311-324 in A. J. Holding, O. W. Heal, S. F. MacLean, Jr., and P. W. Flanagan, editors. Soil organisms and decomposition in tundra. Tundra Biome Steering Committee, Stockholm, Sweden.

Van Cleve, K., and V. Alexander. 1981. Nitrogen cycling in terrestrial tundra and boreal ecosystems. In F. E. Clark and T. Rosswall, editors. Nitrogen cycling in terrestrial ecosystems: Processes, ecosystem strategies, management impacts. Ecological Bulletins-NFR 33:375-404.

Walker, D. A., K. R. Everett, P. J. Webber, and J. Brown. 1980. Geobotanical atlas of the Prudhoe Bay Region, Alaska. United States Army Corps of Engineers, Cold Regions Research and Engineering Laboratory, Hanover, New Hampshire, USA.

Waterhouse, D. F., R. H. Hackman, and J. W. McKeller. 1961. An investigation of chitinase activity in cockroach and termite extracts. Journal of Industrial Physics 6:96112 .

Webber, P. J., and J. D. Ives. 1978. Damage and recovery of tundra vegetation. Environmental Conservation 5:171182.

Wein, R. W., and L. C. Bliss. 1973. Changes in arctic Eriophorum tussock communities following fire. Ecology 54: 845-852.

Wein, R. W., and L. C. Bliss. 1974. Primary production in 
arctic cotton grass tussock tundra communities. Arctic and Alpine Research 6:261-274.

Wilimovsky, N. J., and J. N. Wolfe. 1966. Environments of the Cape Thompson region, Alaska. United States Atomic Energy Commission, Washington, D.C., USA

\section{APPENDIX 1}

$A=$ fraction of potentially mineralizable nitrogen multiplied by $10^{4}$.

ABSMOSSCOVER = ABSCOVER.

ABSCOVER = absolute cover of moss species $\left(\mathrm{m}^{2} / \mathrm{m}^{2}\right)$.

ACCRATE = acclimation rate for moss photosynthesis temperature optimum $\left({ }^{\circ} \mathrm{C} / \mathrm{d}\right)$.

AIRTERM = contribution of wind to potential evaporation $(\mathrm{mm} / \mathrm{d})$.

ALBEDO = surface albedo (ratio).

AVAILNT $=$ nitrogen available for vascular plant or moss growth $\left(\mathrm{g} /\right.$ shoot or $\left.\mathrm{g} / \mathrm{m}^{2}\right)$ or nitrogen available for plant uptake from a given soil layer $\left(\mathrm{g} / \mathrm{m}^{2}\right)$.

AVAILSG = total nonstructural carbohydrate available for vascular plant or moss growth $\left(\mathrm{g} /\right.$ shoot or $\left.\mathrm{g} / \mathrm{m}^{2}\right)$.

AVAILPO $=$ phosphorus available for moss growth $\left(\mathrm{g} / \mathrm{m}^{2}\right)$.

$\mathrm{B}=$ constant for nitrogen mineralization.

$\mathrm{BD}=$ soil bulk density $\left(\mathrm{g} / \mathrm{cm}^{3}\right)$.

BIOMASS = vascular biomass: leaf, stem, and root (g/shoot).

CELL $=$ cellulose in a given soil layer $\left(\mathrm{g} / \mathrm{m}^{2}\right)$.

CHIT $=$ chitin in a given soil layer $\left(\mathrm{g} / \mathrm{m}^{2}\right)$.

COMPENSATE $=$ compensation point for vascular-plant photosynthesis $\left(\mathrm{MJ} \cdot \mathrm{m}^{-2} \cdot \mathrm{d}^{-1}\right)$.

COMPENSATION = compensation point corrected for $24-\mathrm{h}$ arctic day $\left(\mathrm{MJ} \cdot \mathrm{m}^{-2} \cdot \mathrm{d}^{-1}\right)$.

$\mathrm{DAY}=$ number of days since 1 May.

DAY0 = number of days after 1 May when TMP was negative for the last time in the spring.

DAYLFGRO2 = last day for leaf growth.

DECOMP = dry-matter decomposition in a given soil layer $\left(\mathrm{g} \cdot \mathrm{m}^{-2} \cdot \mathrm{d}^{-1}\right)$.

DELTASOILDEPTH $=$ change in thawed soil depth on a given day $(\mathrm{cm})$.

DELTAVP = difference between saturated and actual vapor pressure of air.

DEPTHFACTOR = maximum moss depth per average solar input $\left(\mathrm{cm} \cdot \mathrm{m}^{2} \cdot \mathrm{MJ}^{-1}\right)$.

DEPTHPO = phosphorus content of aboveground dying vascular plants $\left(\mathrm{g} / \mathrm{m}^{2}\right)$.

DKCELL $=$ decomposed cellulose in a given soil layer $\left(\mathrm{g} \cdot \mathrm{m}^{-2} \cdot \mathrm{d}^{-1}\right)$.

DKCHIT $=$ decomposed chitin in a given soil layer $\left(\mathrm{g} \cdot \mathrm{m}^{-2} \cdot \mathrm{d}^{-1}\right)$.

DKHEMI $=$ decomposed hemicellulose in a given soil layer $\left(\mathrm{g} \cdot \mathrm{m}^{-2} \cdot \mathrm{d}^{-1}\right)$.

DKLIGN $=$ decomposed lignin in a given soil layer $\left(\mathrm{g} \cdot \mathrm{m}^{-2} \cdot \mathrm{d}^{-1}\right)$.

DKOPO4 = decay of organic phosphates in a given soil layer $\left(\mathrm{g} \cdot \mathrm{m}^{-2} \cdot \mathrm{d}^{-1}\right)$.

DKPECT $=$ decomposed pectin in a given soil layer $\left(\mathrm{g} \cdot \mathrm{m}^{-2} \cdot \mathrm{d}^{-1}\right)$.

DKPROT $=$ decomposed protein in a given soil layer $\left(\mathrm{g} \cdot \mathrm{m}^{-2} \cdot \mathrm{d}^{-1}\right)$.

DKTNC $=$ decomposed total nonstructural carbohydrate in given soil layer $\left(\mathrm{g} \cdot \mathrm{m}^{-2} \cdot \mathrm{d}^{-1}\right)$.

DRAIN $=$ drainage

DRAINAGE = water drained from given soil layer $(\mathrm{mm} / \mathrm{d})$.

EVAP $=$ water evaporated from soil surface $(\mathrm{mm} / \mathrm{d})$.

EXCHANGNT $=$ exchangeable nitrogen in given soil layer $\left(\mathrm{g} / \mathrm{m}^{2}\right)$.

EXCHANGPO = soil exchangeable inorganic phosphorus in given soil layer $\left(\mathrm{g} / \mathrm{m}^{2}\right)$.
$F=$ fraction of leaf mass dying due to cold.

FERTADD $=$ nitrogen fertilizer available to soil $\left(\mathrm{g} / \mathrm{m}^{2}\right)$.

FERTN $=$ nitrogen fertilizer added to soil $\left(\mathrm{g} / \mathrm{m}^{2}\right)$.

FIELDCAP = field capacity of given soil layer $\left(\mathrm{g} / \mathrm{cm}^{3}\right)$.

FOV $=$ relative overcast skies (fraction of sky covered by clouds).

GLFM2LF $=$ specific leaf mass $\left(\mathrm{g} / \mathrm{m}^{2}\right)$.

GPM2 = shoot density $\left(\right.$ shoots $\left./ \mathrm{m}^{2}\right)$.

GROFACTOR = ratio of actual to potential growth (fraction).

HEATSUM = sum of the daily mean soil temperature above zero ('day).

HEMI $=$ hemicellulose in a given soil layer $\left(\mathrm{g} / \mathrm{m}^{2}\right)$.

HTMIN = minimum heat sum for leaf and stem growth ( ${ }^{\circ}$ day).

HTSUMGND = sum of the daily mean ground surface temperature above zero ('day).

INITLFMS $=$ initial leaf mass $(\mathrm{g} / \mathrm{shoot})$

IRNET = net long-wave radiation $\left(\mathrm{MJ} \cdot \mathrm{m}^{-2} \mathrm{~d}^{-1}\right)$.

IRSKY $=$ long-wave radiation from the sky $\left(\mathrm{MJ} \cdot \mathrm{m}^{-2} \cdot \mathrm{d}^{-1}\right)$.

IRUP = long-wave radiation from the tundra surface $\left(\mathrm{MJ} \cdot \mathrm{m}^{-2} \cdot \mathrm{d}^{-1}\right)$.

$\mathrm{K}=$ constant for soil mineralization.

$\mathrm{LAI}=$ vascular-plant leaf area index $\left(\mathrm{m}^{2} / \mathrm{m}^{2}\right)$.

LFALLOCATION = allocation of growth to leaves (fraction).

LFDETH $=$ leaf death $\left(g \cdot \operatorname{shoot}^{-1} \cdot d^{-1}\right)$.

LFGRO = leaf growth $\left(\mathrm{g} / \operatorname{shoot}^{-1} \cdot \mathrm{d}^{-1}\right)$.

LFGROMX = maximum possible leaf growth rate $\left(\mathrm{g} \cdot \operatorname{shoot}^{-1} \cdot \mathrm{d}^{-1}\right)$.

LFGROTF = leaf growth temperature function (fraction).

LFMS $=$ leaf dry mass $(\mathrm{g} / \mathrm{shoot})$.

LFN = leaf nitrogen ( $\mathrm{mg} / \mathrm{g}$ dry mass).

LFNDETH $=$ leaf nitrogen content at death $(\mathrm{mg} / \mathrm{g})$.

LFNEWMS $=$ new leaf mass grown this year $(\mathrm{g} / \mathrm{shoot})$.

LEPDETH $=$ leaf phosphorus content at death $(\mathrm{mg} / \mathrm{g})$.

LFRSP $=$ leaf respiration as sugar produced $\left(g \cdot \operatorname{shoot}^{-1} \cdot \mathrm{d}^{-1}\right)$.

LFSG = leaf storage carbohydrate $\left(\mathrm{CH}_{2} \mathrm{O}, \mathrm{mg} / \mathrm{g}\right.$ dry mass $)$.

LIMRATIO = $($ sugar demand/sugar availability $) /($ nitrogen demand/nitrogen availability). (Expressed as a fraction.)

M1, M2, M3, M4 = moss maintenance respiration factors.

MAINTRSP $=$ moss maintenance respiration $\left(\mathrm{CH}_{2} \mathrm{O}\right.$, $\left.\mathrm{g} \cdot \mathrm{m}^{-2} \cdot \mathrm{d}^{-1}\right)$.

MAXDEPTH $=$ maximum depth of mosses for a given solar irradiance $(\mathrm{cm})$.

MAXGRO = maximum dry-mass growth rate of mosses $\left(\mathrm{g} \cdot \mathrm{g}^{-1} \cdot \mathrm{d}^{-1}\right)$.

MINDETHTEMP = minimum temperature below which death begins $\left({ }^{\circ} \mathrm{C}\right)$.

MINERALTHICK $=$ thickness of the mineral soil layer $(\mathrm{cm})$.

MOSSBULKDEN $=$ moss bulk density $\left(\mathrm{g} / \mathrm{cm}^{3}\right)$.

MOSSDEATH $=$ death of moss tissue $\left(\mathrm{g} / \mathrm{m}^{2}\right)$.

MOSSDETHPO $=$ phosphorus content of dying mosses $\left(\mathrm{g} / \mathrm{m}^{2}\right)$.

MOSSGRO $=$ moss dry mass growth $\left(g \cdot \mathrm{m}^{-2} \cdot \mathrm{d}^{-1}\right)$.

MOSSMS $=$ moss biomass $\left(\mathrm{g} / \mathrm{m}^{2}\right)$.

MOSSNT $=$ moss nitrogen content of all species $\left(\mathrm{g} / \mathrm{m}^{2}\right)$.

MOSSNUP $=$ nitrogen taken up by moss $\left(\mathrm{g} / \mathrm{m}^{2}\right)$.

MOSSPO $=$ moss phosphorus content of all species $\left(\mathrm{g} / \mathrm{m}^{2}\right)$.

MOSSPS $=$ moss photosynthesis $\left(\mathrm{CH}_{2} \mathrm{O}, \mathrm{g} \cdot \mathrm{m}^{-2} \cdot \mathrm{d}^{-1}\right)$.

MOSSPUP $=$ phosphorus taken up by moss $\left(\mathrm{g} / \mathrm{m}^{2}\right)$.

MOSSSG = moss totalnonstructural carbohydrate $\left(\mathrm{CH}_{2} \mathrm{O}, \mathrm{g} / \mathrm{m}^{2}\right)$.

$\mathrm{MYCO}=$ nutrient uptake adjustment factor $(\mathrm{m} / \mathrm{m})$.

NFIELD = actual nitrogen mineralized $(\mathrm{mg} / \mathrm{kg})$.

$\mathrm{NO}=$ potentially mineralizable nitrogen in a given soil layer $(\mathrm{mg} / \mathrm{kg})$.

NOPT $=$ optimum nitrogen mineralized $(\mathrm{mg} / \mathrm{kg})$.

NTCONC $=$ nitrogen concentration of rain $(\mathrm{mg} / \mathrm{L})$.

NTDEMAND = nitrogen demand for vascular plant growth (g/shoot).

NTDRAIN = movement of soluble nitrogen from one soil horizon to another $\left(\mathrm{g} / \mathrm{m}^{2}\right)$. 
NTLEACH $=$ nitrogen lost from dead vascular plants by leaching $\left(\mathrm{g} / \mathrm{m}^{2}\right)$.

NTMIN = dry mass of nitrogen mineralized in a given layer $\left(\mathrm{g} \cdot \mathrm{m}^{-2} \cdot \mathrm{d}^{-1}\right)$.

NTPRECIP $=$ nitrogen in precipitation $\left(\mathrm{g} / \mathrm{m}^{2}\right)$.

NTUP $=$ nitrogen taken up by one species $(\mathrm{g} /$ shoot $)$.

OMTHICK $=$ thickness of all organic soil layers $(\mathrm{cm})$.

OPTWC $=$ optimum moss water content (g/g dry mass).

ORGANIC $=$ total organic phosphorus in a given soil layer $\left(\mathrm{g} / \mathrm{m}^{2}\right)$.

ORGANICP $=$ organic phosphorus in a given soil layer $\left(\mathrm{g} / \mathrm{m}^{2}\right)$.

PARTMOSSNUP = moss nitrogen uptake due to evaporation from top soil layer $\left(\mathrm{g} / \mathrm{m}^{2}\right)$.

PEAKLFMS = maximum observed leaf dry mass ( $\mathrm{g} / \mathrm{shoot}$ ).

PEAKRTMS $=$ maximim observed root dry mass $(\mathrm{g} / \mathrm{shoot})$.

PECT $=$ pectin in a given soil layer $\left(\mathrm{g} / \mathrm{m}^{2}\right)$.

PERCENTNT $=$ percent nitrogen in biomass.

PMAX = maximum photosynthetic rate $\left(\mathrm{CO}^{2}\right.$ uptake, $\left.\mathrm{mg} \cdot \mathrm{g}^{-1} \cdot \mathrm{h}^{-1}\right)$.

POCONTENT $=$ phosphorus concentration of rain $(\mathrm{mg} / \mathrm{LO})$. PODRAIN = phosphorus drained from given soil layer $\left(\mathrm{g} / \mathrm{m}^{2}\right)$.

POLEACH $=$ phosphorus lost from dead vascular plants by

leaching $\left(\mathrm{g} / \mathrm{m}^{2}\right)$ or fraction of phosphorus lost by leaching (fraction).

POPRECIP $=$ phosphorus in precipitation $\left(\mathrm{g} / \mathrm{m}^{2}\right)$.

POTEVAP $=$ potential evaporation $(\mathrm{mm} / \mathrm{d})$.

POTLFGRO = potential leafgrowth on a given day (g/shoot).

POTRTGRO $=$ potential root growth $\left(\mathrm{g} \cdot \mathrm{shoot}^{-1} \cdot \mathrm{d}^{-1}\right)$.

POTSTGRO $=$ potential stem growth $\left(\mathrm{g} \cdot \mathrm{shoot}^{-1} \cdot \mathrm{d}^{-1}\right)$.

POUP $=$ phosphorus taken up by roots $(\mathrm{g} / \mathrm{g}$ root $)$.

PRECIP $=$ precipitation $(\mathrm{mm} / \mathrm{d})$.

PROT $=$ protein in a given soil layer $\left(\mathrm{g} / \mathrm{m}^{2}\right)$.

$\mathrm{PS}=$ sugar gained from photosynthesis $\left(\mathrm{g} \cdot \operatorname{shoot}^{-1} \cdot \mathrm{d}^{-1}\right)$.

PUPCAP = phosphate root uptake capacity (g/g root).

$\mathrm{Q}_{10}=$ respiration rate parameter.

QNET = contribution of radiation to potential evaporation (mm/d).

$\mathrm{R}=$ respiration rate function (tissue $\mathrm{C}, \mathrm{g} \cdot \mathrm{g}^{-1} \cdot \mathrm{d}^{-1}$ ).

$\mathrm{RO}=$ respiration rate of temperature (TO).

$\mathrm{RH}=$ relative humidity $(\%)$.

$\mathrm{RNET}=$ net radiation $\left(\mathrm{MJ} \cdot \mathrm{m}^{-2} \cdot \mathrm{d}^{-1}\right)$.

$\mathrm{RSP}=$ total vascular-plant respiration (as sugar) for given species $\left(g \cdot \operatorname{shoot}^{-1} \cdot d^{-1}\right)$.

RTALLOCATION = allocation of growth to roots (fraction).

RTDETHPO $=$ phosphorus content of dying roots in a given layer $\left(\mathrm{g} / \mathrm{m}^{2}\right)$.

RTDIS = fraction of total absorbing roots in a given layer (fraction).

RTGRO = root growth $\left(g \cdot \operatorname{shoot}^{-1} \cdot \mathrm{d}^{-1}\right)$.

RTGROMX = maximum possible root growth rate $\left(\mathrm{g} \cdot \operatorname{shoot}^{-1} \cdot \mathrm{d}^{-1}\right)$.

RTLGTH = effective root length of a species in a given soil layer $(\mathrm{m} / \mathrm{shoot})$.

RTMS = absorbing root dry mass (g/shoot).

$\mathrm{RTN}=$ root nitrogen (mg/g dry mass).

RTNTF = relative root growth factor within soil layer based on $\mathrm{N}$ (fraction).

RTSG = root storage carbohydrate in a given soil layer $\left(\mathrm{CH}_{2} \mathrm{O}\right.$, $\mathrm{mg} / \mathrm{g}$ dry mass).

SDEMAND = total nonstructural carbohydrate demand for growth $(\mathrm{g} /$ shoot).

SLINORGN $=$ SLINORGNT.

SLINORGNT = soluble inorganic nitrogen in the soil solution $\left(\mathrm{g} / \mathrm{m}^{2}\right)$.

SLINORGPO = soluble inorganic phosphorus in the soil solution $\left(\mathrm{g} / \mathrm{m}^{2}\right)$.

SLOPE $=$ slope of the vapor pressure curve $\left(/{ }^{\circ} \mathrm{C}\right)$.

SMAX = annual maximum daily solar irradiance $\left(\mathrm{MJ} \cdot \mathrm{m}^{-2} \cdot \mathrm{d}^{-1}\right)$.

SMIN = annual minimum daily solar irradiance $\left(\mathrm{MJ} \cdot \mathrm{m}^{-2} \cdot \mathrm{d}^{-1}\right)$.
SOILCELL $=$ cellulose content in given soil layer $\left(\mathrm{g} / \mathrm{m}^{2}\right)$.

SOILDEPTH $=$ depth of thawed soil on given day $(\mathrm{cm})$.

SOILHEMI = hemicellulose content in given soil layer $\left(\mathrm{g} / \mathrm{m}^{2}\right)$.

SOILLIGN = lignin content in given soil layer $\left(\mathrm{g} / \mathrm{m}^{2}\right)$.

SOILNT $=$ initial soil introgen in given layer (\%).

SOILPORG $=$ soil organic phosphorus in a given soil layer $\left(\mathrm{g} / \mathrm{m}^{2}\right)$.

SOILTNC $=$ total nonstructural carbohydrate in given layer $\left(\mathrm{g} / \mathrm{m}^{2}\right)$.

SOLAR = solar irradiance above vascular-plant canopy $\left(\mathrm{MJ} \cdot \mathrm{m}^{-2} \cdot \mathrm{d}^{-1}\right)$.

SOLARABS $=$ solar irradiance absorbed by vascular plant canopy $\left(\mathrm{MJ} \cdot \mathrm{m}^{-2} \cdot \mathrm{d}^{-1}\right)$.

SOLARBEFORE $=$ solar irradiance available at moss surface before attenuation by daily humidity $\left(\mathrm{MJ} / \mathrm{m}^{2}\right)$.

SOLARF $=$ solar irradiance function (fraction).

SOLARFACTOR = photosynthetic potential as fraction of maximum rate (fraction).

SOLARMOSS = solar irradiance incident on moss $\left(\mathrm{MJ} \cdot \mathrm{m}^{-2} \cdot \mathrm{d}^{-1}\right)$.

SOLARPS = solar irradiance incident on vascular plants $\left(\mathrm{MJ} \cdot \mathrm{m}^{-2} \cdot \mathrm{d}^{-1}\right)$.

STALLOCATION = allocation of growth to stems (fraction).

STANDDEADNT $=$ nitrogen in standing dead plant material $\left(\mathrm{g} / \mathrm{m}^{2}\right)$.

STGRO $=$ stem growth $\left(g \cdot \operatorname{shoot}^{-1} \cdot \mathrm{d}^{-1}\right)$.

STMS = stem and large root dry mass (g/shoot).

$\mathrm{STN}=$ stem nitrogen $(\mathrm{mg} / \mathrm{g}$ dry mass).

STSG = stem storage carbohydrate $\left(\mathrm{CH}_{2} \mathrm{O}, \mathrm{mg} / \mathrm{g}\right.$ dry mass $)$.

SYSTEMLOSS = loss of nitrogen from the soil by deep drainage $\left(\mathrm{g} / \mathrm{m}^{2}\right)$.

$\mathrm{TO}=$ base temperature defining the vascular plant respiration rate function $\left({ }^{\circ} \mathrm{C}\right)$.

TAMP $=$ annual temperature fluctuation about the mean $\left({ }^{\circ} \mathrm{C}\right)$.

TGND $=$ mean tundra surface temperature on a given day $\left({ }^{\circ} \mathrm{C}\right)$.

THAWF $=$ fraction of soil layer that is thawed (fraction).

THAWTHICK $=$ thickness of thawed soil in given layer $(\mathrm{cm})$.

THAWWATER $=$ water thawed in a given soil layer on given day $\left(\mathrm{g} / \mathrm{cm}^{3}\right)$.

THETAMIN = minimum soil water content of given soil layer $\left(\mathrm{g} / \mathrm{cm}^{3}\right)$.

THICK $=$ thickness of given soil layer $(\mathrm{cm})$.

TMEAN $=$ annual mean air temperature $\left({ }^{\circ} \mathrm{C}\right)$.

$\mathrm{TMP}=$ mean air temperature on a given day $\left({ }^{\circ} \mathrm{C}\right)$.

$\mathrm{TMPF}=$ temperature function (fraction).

TOPT $=$ temperature optimum for moss photosynthesis $\left({ }^{\circ} \mathrm{C}\right)$.

TOTALOGANIC $=$ total organic content of soil in given layer $\left(\mathrm{g} / \mathrm{m}^{2}\right)$.

TOTNT $=$ nitrogen content of vascular plant (g/shoot).

TOTNTUP = nitrogen taken up by one species from all soil layers (g/shoot).

TOTNUP $=$ VASCNTUP.

TOTRTLGTH = effective root length over all soil layers (cm/shoot).

TOTSG $=$ total vascular nonstructural carbohydrate ( $\mathrm{g} /$ shoot).

TOTTRMS = total vascular root mass over all soil layers (g/shoot).

TSOIL $=$ soil temperature of given soil layer $\left({ }^{\circ} \mathrm{C}\right)$

TURNDETH = leaf death per day due to seasonal leaf turnover $\left(\mathrm{g} \cdot \operatorname{shoot}^{-1} \cdot \mathrm{d}^{-1}\right)$.

TURNOVERMASS = vascular biomass turning over $\left(\mathrm{g} \cdot \operatorname{shoot}^{-1} \cdot \mathrm{d}^{-1}\right)$.

VAIR = vapor pressure of the air $\left(\mathrm{mb}^{*}\right)$.

VAIRSAT $=$ saturated vapor pressure of the air $\left(\mathrm{mb}^{*}\right)$.

VASCNTUP = vascular-plant nitrogen uptake from given soil layer $\left(\mathrm{g} / \mathrm{m}^{2}\right)$.

* In the output of the program, the units are converted to megapascals. 
VASCRTLGTH = vascular-plant effective root length $\left(\mathrm{cm} / \mathrm{m}^{2}\right)$.

WATER $=$ soil water content of given soil layer $\left(\mathrm{g} / \mathrm{cm}^{3}\right)$.

WATERF $=$ soil water function (fraction).

$\mathrm{WC}=$ moss water content ( $\mathrm{g} / \mathrm{g}$ dry mass).
WIND $=$ total wind passage $(\mathrm{km} / \mathrm{d})$.

$\mathrm{X}=$ correction factor to convert maximum vascular-plant photosynthesis to mean (fraction).

ZEROWC $=$ moss water content at photosynthetic compensation point ( $\mathrm{g} / \mathrm{g}$ dry mass).

\section{APPENDIX 2}

PARAMETER VAlUes FOR ARTUS

TABLE A1. Parameter values for equations calculating vascular-plant growth and nutrient balance at death.

\begin{tabular}{|c|c|c|c|c|c|c|c|c|c|c|}
\hline \multirow[b]{3}{*}{ Parameter } & \multirow[b]{3}{*}{ Program name* } & \multirow{2}{*}{\multicolumn{6}{|c|}{ Value }} & \multicolumn{2}{|c|}{ Confidence $†$} & \multirow[b]{3}{*}{ Reference } \\
\hline & & & & & & & & \multirow{2}{*}{$\begin{array}{l}\text { Eagle } \\
\text { Creek }\end{array}$} & \multirow{2}{*}{$\begin{array}{c}\text { Tus- } \\
\text { sock } \\
\text { tundra }\end{array}$} & \\
\hline & & B.n. & V.u. & L.d. & V.v. $-i$. & E.v. & C.b. & & & \\
\hline $\begin{array}{l}\text { Maximum leaf growth rate } \\
\left(\mathrm{mg} \cdot \operatorname{shoot}^{-1} \cdot \mathrm{d}^{-1}\right)\end{array}$ & LFGROMX & 6 & 6 & 3.7 & 3.6 & 6 & 3 & $\mathrm{~b}$ & $\mathrm{c}$ & Stoner et al. (1982) \\
\hline $\begin{array}{l}\text { Minimum heat sum for growth } \\
\text { (degree-day) }\end{array}$ & HTMIN & 32 & 32 & 260 & 315 & 10 & 10 & d & d & estimate \\
\hline Last day for leaf growth & DAYLFGROW2 & 66 & 66 & 92 & 95 & 106 & 106 & d & d & estimate \\
\hline Maximum root growth rate $(\mathrm{mg} / \mathrm{g})$ & RTGROMX & 1.5 & 1.5 & 1.0 & 1.0 & 2.0 & 3.0 & d & d & estimate \\
\hline $\begin{array}{l}\text { Maximum observed leaf dry mass } \\
(\mathrm{mg} / \text { shoot })\end{array}$ & PEAKLFMS & 17 & 17 & 23 & 40 & 35 & 106 & d & d & estimate \\
\hline $\begin{array}{l}\text { Maximum possible root dry mass } \\
(\mathrm{mg} / \text { shoot })\end{array}$ & PEAKRTMS & 50 & 50 & 150 & 120 & 20 & 100 & d & d & estimate \\
\hline $\begin{array}{l}\text { Optimum air temperature for leaf } \\
\text { growth }\left({ }^{\circ} \mathrm{C}\right)\end{array}$ & $\cdots$ & 10 & 10 & 15 & 20 & 22 & 10 & d & d & estimate \\
\hline $\begin{array}{l}\text { Minimum air temperature for leaf } \\
\text { growth }\left({ }^{\circ} \mathrm{C}\right)\end{array}$ & $\cdots$ & 0 & 0 & 5 & 2 & 2 & 0 & $\mathrm{~d}$ & d & estimate \\
\hline $\begin{array}{l}\text { Optimum soil temperature for root } \\
\text { growth }\left({ }^{\circ} \mathrm{C}\right)\end{array}$ & $\cdots$ & 15 & 15 & 15 & 15 & 15 & 15 & d & d & estimate \\
\hline Nitrogen content at leaf death $(\mathrm{mg} / \mathrm{g})$ & LFNDETH & 7.0 & 7.0 & 6.5 & 6.5 & 7.0 & 8.5 & b & c & $\begin{array}{l}\text { F. W. Murray (per- } \\
\text { sonal communication) }\end{array}$ \\
\hline $\begin{array}{l}\text { Phosphorous content at leaf death } \\
(\mathrm{mg} / \mathrm{g})\end{array}$ & LFPDETH & 0.8 & 0.8 & 0.8 & 0.5 & 1.3 & 0.7 & b & $\mathrm{c}$ & $\begin{array}{l}\text { F. W. Murray (per- } \\
\text { sonal communication) }\end{array}$ \\
\hline $\begin{array}{l}\text { Beginning day for leaf death due to cold } \\
(1 \text { May = day 1) }\end{array}$ & $\cdots$ & 60 & 60 & 45 & 45 & 80 & 60 & d & d & estimate \\
\hline Fraction of leaf mass dying due to cold & $\mathrm{F}$ & 0.05 & 0.05 & 0.01 & 0.01 & 0.05 & 0.05 & $\cdots$ & d & estimate \\
\hline $\begin{array}{l}\text { Temperature below which death begins } \\
\left({ }^{\circ} \mathrm{C}\right)\end{array}$ & MINDETHTEMP & 10 & 10 & 4 & 3 & 5 & 5 & $\cdots$ & $\mathrm{d}$ & estimate \\
\hline $\begin{array}{l}\text { Beginning day for leaf death due to } \\
\text { turnover }(1 \text { May = day } 1)\end{array}$ & $\cdots$ & 1000 & 1000 & 75 & 75 & 1 & 1 & $\cdots$ & $\mathrm{d}$ & estimate \\
\hline $\begin{array}{l}\text { Death per day due to seasonal leaf } \\
\text { turnover }(\mathrm{g} / \text { shoot })\end{array}$ & TURNDEATH & 0 & 0 & 0.01 & 0.01 & 0.03 & 0.02 & $\cdots$ & $\mathrm{d}$ & estimate \\
\hline
\end{tabular}

* See Appendix 1 for definitions.

$\dagger$ For explanation of degree of confidence symbols a-d, see Table 2.

TABLE A2. Parameter values for equations calculating vascular-plant photosynthesis.

\begin{tabular}{|c|c|c|c|c|c|}
\hline \multirow[b]{2}{*}{ Parameter and species } & \multirow[b]{2}{*}{ Program name* } & \multirow[b]{2}{*}{ Value } & \multicolumn{2}{|c|}{ Confidence $\dagger$} & \multirow[b]{2}{*}{ Reference } \\
\hline & & & $\begin{array}{l}\text { Eagle } \\
\text { Creek }\end{array}$ & $\begin{array}{c}\text { Tus- } \\
\text { sock } \\
\text { tundra }\end{array}$ & \\
\hline $\begin{array}{l}\text { Maximum photosynthetic rate } \\
\quad\left(\mathrm{CO}_{2}, \mathrm{mg} \cdot \mathrm{g}^{-1} \cdot \mathrm{h}^{-1}\right)\end{array}$ & PMAX & & & & \\
\hline $\begin{array}{l}\text { Betula nana } \\
\text { Vaccinium uliginosum }\end{array}$ & & 29.3 & $\mathrm{c}$ & c & Bigger and Oechel (1982) \\
\hline Ledum palustre & & $\begin{array}{r}29.3 \\
9.1\end{array}$ & $\begin{array}{l}\mathrm{c} \\
\mathrm{c}\end{array}$ & $\begin{array}{l}\mathrm{c} \\
\mathrm{c}\end{array}$ & Bigger and Oechel (1982) \\
\hline Vaccinium vitis-idaea & & 4.5 & c & c & Bigger and Oechel (1982) \\
\hline Eriophorum vaginatum & & 16.2 & $\mathrm{c}$ & c & Bigger and Oechel (1982) \\
\hline Carex bigelowii & & 14.0 & c & c & Bigger and Oechel (1982) \\
\hline Arctagrostis latifolia & & 47.0 & d & $\mathrm{d}$ & Johnson and Tieszen (1976) \\
\hline
\end{tabular}




\section{APPENDIX 2}

TABle A2. Continued.

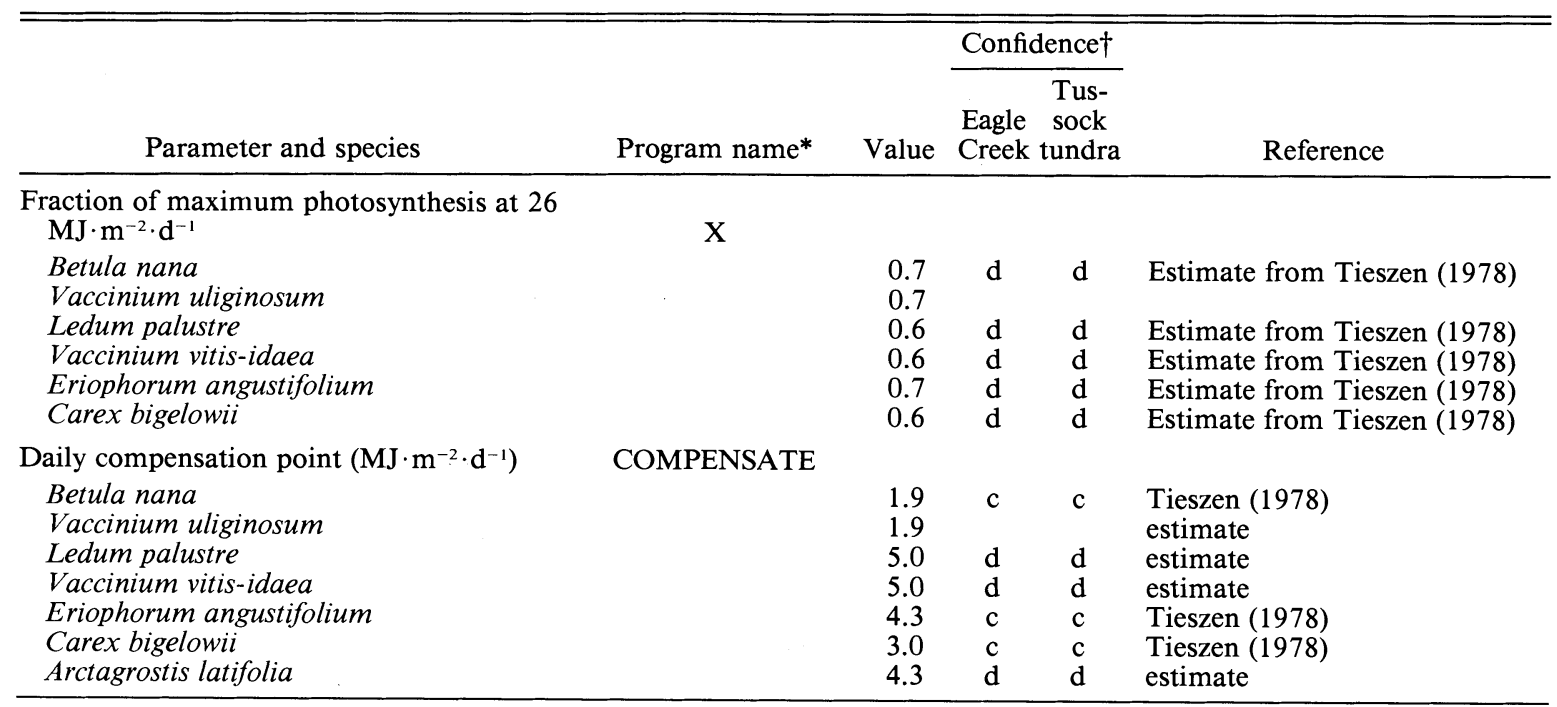

* See Appendix 1 for definitions.

$\dagger$ For explanation of degree of confidence symbols a-d, see Table 2.

TABLE A3. Initial values (early season) for the compartments or variables of the four moss types.

\begin{tabular}{|c|c|c|c|c|c|}
\hline \multirow[b]{2}{*}{ Compartment or variable } & \multirow[b]{2}{*}{ Program name* } & \multirow[b]{2}{*}{ Value } & \multicolumn{2}{|c|}{ Confidence $\dagger$} & \multirow[b]{2}{*}{ Reference } \\
\hline & & & $\begin{array}{l}\text { Eagle } \\
\text { Creek }\end{array}$ & $\begin{array}{l}\text { Tus- } \\
\text { sock } \\
\text { tundra }\end{array}$ & \\
\hline Cover (absolute percent) & ABSCOVER & & & & \\
\hline Sphagnum capillaceum & & 21.2 & a & $\mathrm{b}$ & Alpert and Oechel (1982) \\
\hline Dicranum elongatum & & 11.0 & $\mathrm{a}$ & $\mathrm{b}$ & Alpert and Oechel (1982) \\
\hline Polytrichum commune & & 7.4 & a & b & Alpert and Oechel (1982) \\
\hline Other & & 5.8 & a & $\mathrm{b}$ & Alpert and Oechel (1982) \\
\hline Biomass $\left(\mathrm{g} / \mathrm{m}^{2}\right)$ & MOSSMS & & & & \\
\hline Sphagnum capillaceum & & 134 & b & $\mathrm{c}$ & Chapin et al. (1979) \\
\hline Dicranum elongatum & & 70 & $\mathrm{~d}$ & $\mathrm{~d}$ & estimate \\
\hline Polytrichum commune & & 36 & d & $\mathrm{d}$ & estimate \\
\hline Polytrichum stems & & 47 & $\mathrm{~d}$ & $\mathrm{~d}$ & estimate \\
\hline Other & & 30 & $\mathrm{~d}$ & $\mathrm{~d}$ & Chapin et al. (1979) \\
\hline Total & & 317 & & & Shaver and Cutler (1979) \\
\hline $\begin{array}{l}\text { Total nonstructural carbohydrate } \\
\text { (g/g dry mass) }\end{array}$ & MOSSSG & & & & \\
\hline Sphagnum capillaceum & & 0.05 & c & $\mathrm{c}$ & estimate \\
\hline Dicranum elongatum & & 0.05 & b & $\mathrm{c}$ & Hicklenton and Oechel (1977) \\
\hline Polytrichum commune & & 0.05 & c & $\mathrm{c}$ & $\begin{array}{l}\text { F. S. Chapin (personal obser- } \\
\text { vation) }\end{array}$ \\
\hline Other & & 0.05 & c & $\mathrm{c}$ & $\begin{array}{l}\text { F. S. Chapin (personal obser- } \\
\text { vation) }\end{array}$ \\
\hline Nitrogen content (g/g dry mass) & MOSSNT & & & & \\
\hline Sphagnum capillaceum & & 0.008 & $\mathrm{~b}$ & $\mathrm{c}$ & $\begin{array}{l}\text { S. K. Skre and W. C. Oechel } \\
\text { (personal observation) }\end{array}$ \\
\hline Dicranum elongatum & & 0.008 & $\mathrm{~d}$ & $\mathrm{~d}$ & estimate \\
\hline Polytrichum commune & & 0.010 & $\mathrm{a}$ & $\mathrm{b}$ & Chapin et al. (1980) \\
\hline Other & & 0.008 & $\mathrm{~d}$ & $\mathrm{~d}$ & estimate \\
\hline Phosphorus content ( $\mathrm{g} / \mathrm{g}$ dry mass) & MOSSPO & & & & \\
\hline Sphagnum capillaceum & & 0.001 & $\mathrm{~b}$ & c & estimate \\
\hline Dicranum elongatum & & 0.001 & b & c & estimate \\
\hline Polytrichum commune & & 0.001 & $\mathrm{a}$ & b & Chapin et al. (1980) \\
\hline Other & & 0.001 & $\mathrm{~b}$ & $\mathrm{c}$ & estimate \\
\hline
\end{tabular}

* See Appendix 1 for definitions.

$\dagger$ For explanation of degree of confidence symbols a-d, see Table 2. 
TABle A4. Parameter values for equations calculating the carbon and nutrient balance of the four moss types.

\begin{tabular}{|c|c|c|c|c|c|}
\hline \multirow[b]{2}{*}{ Parameter and species } & \multirow[b]{2}{*}{ Program name* } & \multirow[b]{2}{*}{ Value } & \multicolumn{2}{|c|}{ Confidence $\dagger$} & \multirow[b]{2}{*}{ Reference } \\
\hline & & & $\begin{array}{l}\text { Eagle } \\
\text { Creek }\end{array}$ & $\begin{array}{c}\text { Tus- } \\
\text { sock } \\
\text { tundra }\end{array}$ & \\
\hline $\begin{array}{l}\text { Water content at photosynthetic } \\
\text { compensation ( } \mathrm{g} / \mathrm{g} \text { dry mass) }\end{array}$ & ZEROWC & & & & \\
\hline Sphagnum capillaceum & & 0.62 & b & $\mathrm{c}$ & Skre and Oechel (1981) \\
\hline Dicranum elongatum & & 0.25 & b & $\mathrm{c}$ & estimate \\
\hline Polytrichum commune & & 0.25 & $\mathrm{c}$ & $\mathrm{d}$ & Skre and Oechel (1981) \\
\hline Other & & 0.25 & d & $\mathrm{d}$ & estimate \\
\hline $\begin{array}{l}\text { Water content for maximum photo- } \\
\text { synthesis ( } \mathrm{g} / \mathrm{g} \text { dry mass) }\end{array}$ & OPTWC & & & & \\
\hline Sphagnum capillaceum & & 7.25 & b & $\mathrm{c}$ & Skre and Oechel (1981) \\
\hline Dicranum elongatum & & 2.0 & $\mathrm{c}$ & $\mathrm{c}$ & estimate \\
\hline Polytrichum commune & & 1.0 & b & $\mathrm{c}$ & Skre and Oechel (1981) \\
\hline Other & & 2.0 & $\mathrm{~d}$ & $\mathrm{~d}$ & estimate \\
\hline $\begin{array}{l}\text { Maximum photosynthetic rate } \\
\left(\mathrm{CO}_{2} \text { uptake per unit dry mass, }\right. \\
\left.\left[\mathrm{mg} \cdot \mathrm{g}^{-1} \cdot \mathrm{h}^{-1}\right]\right)\end{array}$ & PMAX & & & & \\
\hline Sphagnum capillaceum & & 1.27 & $\mathrm{~b}$ & c & Skre and Oechel (1981) \\
\hline Dicranum elongatum & & 1.05 & b & $\mathrm{c}$ & Oechel (1976) \\
\hline Polytrichum commune & & 1.27 & $\mathrm{~b}$ & $\mathrm{c}$ & Skre and Oechel (1981) \\
\hline Other & & 1.05 & $\mathrm{~d}$ & $\mathrm{~d}$ & estimate \\
\hline \multicolumn{6}{|l|}{$\begin{array}{l}\text { Maintenance respiration at four } \\
\text { temperatures }\left(\mathrm{CO}_{2} \text { release per }\right. \\
\left.\text { unit dry mass }\left[\mathrm{g} \cdot \mathrm{g} \text { dry }{ }^{-1} \cdot \mathrm{d}^{-1}\right]\right)\end{array}$} \\
\hline \multicolumn{6}{|l|}{ Sphagnum capillaceum } \\
\hline $0^{\circ} \mathrm{C}$ & & 0.001 & b & $\mathrm{b}$ & Skre and Oechel (1981) \\
\hline $10^{\circ}$ & & 0.005 & & & \\
\hline $20^{\circ}$ & & 0.008 & & & \\
\hline \multirow{2}{*}{\multicolumn{6}{|c|}{$\begin{array}{l}\text { Dicranum elongatum and other } \\
\text { mosses }\end{array}$}} \\
\hline & & & & & \\
\hline $0^{\circ} \mathrm{C}$ & & 0.003 & b & b & Oechel (1976) \\
\hline $10^{\circ}$ & & 0.008 & & & \\
\hline $20^{\circ}$ & & 0.019 & & & \\
\hline $30^{\circ}$ & & 0.035 & & & \\
\hline Polytrichum commune & & & & & \\
\hline $0^{\circ} \mathrm{C}$ & & 0.0128 & b & b & $\begin{array}{l}\text { Sveinbjornsson and Oechel } \\
\text { (1983) }\end{array}$ \\
\hline $10^{\circ}$ & & 0.0288 & & & \\
\hline $\begin{array}{l}20^{\circ} \\
30^{\circ}\end{array}$ & & $\begin{array}{l}0.0619 \\
0.0747\end{array}$ & & & \\
\hline $\begin{array}{l}\text { Maximum rate of growth } \\
\left(\text { dry mass, } g \cdot g^{-1} \cdot d^{-1}\right)\end{array}$ & MAXGRO & & & & \\
\hline Sphagnum capillaceum & & 0.03 & d & $\mathrm{d}$ & estimate \\
\hline Dicranum elongatum & & 0.03 & d & d & \\
\hline Polytrichum commune & & 0.04 & d & d & \\
\hline Other & & 0.03 & d & $\mathrm{d}$ & \\
\hline Bulk density $\left(\mathrm{g} / \mathrm{cm}^{3}\right)$ & MOSSBULKDEN & & & & \\
\hline Sphagnum capillaceum & & 0.018 & b & $\mathrm{b}$ & Skre et al. (1983) \\
\hline Dicranum elongatum & & 0.008 & b & b & Skre et al. (1983) \\
\hline Polytrichum commune & & 0.008 & b & b & Skre et al. (1983) \\
\hline Other & & 0.008 & $\mathrm{~d}$ & $\mathrm{~d}$ & Skre et al. (1983) \\
\hline Acclimatization rate $\left({ }^{\circ} \mathrm{C} / \mathrm{d}\right)$ & ACCRATE & & & & \\
\hline Sphagnum capillaceum & & 0.75 & & & Hicklenton and Oechel (1977) \\
\hline Dicranum elongatum & & 0.75 & & & \\
\hline Polytrichum commune & & 0.75 & & & \\
\hline Other & & 0.75 & & & \\
\hline $\begin{array}{l}\text { Depth per average solar input } \\
\left(\mathrm{cm} /\left[\mathrm{MJ} \cdot \mathrm{m}^{-2} \cdot \mathrm{d}^{-1}\right]\right)\end{array}$ & DEPTHFACTOR & & & & \\
\hline Sphagnum capillaceum & & 0.42 & $\mathrm{~b}$ & b & Skre and Oechel (1981) \\
\hline Dicranum elongatum & & 0.07 & $\mathrm{~b}$ & b & Skre and Oechel (1981) \\
\hline Polytrichum commune & & 0.11 & $\mathrm{~b}$ & b & Skre and Oechel (1981) \\
\hline Other & & 0.07 & $\mathrm{~b}$ & $\mathrm{~b}$ & Skre and Oechel (1981) \\
\hline
\end{tabular}




\section{APPENDIX 2}

TABle A4. Continued.

\begin{tabular}{|c|c|c|c|c|c|}
\hline \multirow[b]{2}{*}{ Parameter and species } & \multirow[b]{2}{*}{ Program name* } & \multirow[b]{2}{*}{ Value } & \multicolumn{2}{|c|}{ Confidence $†$} & \multirow[b]{2}{*}{ Reference } \\
\hline & & & $\begin{array}{l}\text { Eagle } \\
\text { Creek }\end{array}$ & $\begin{array}{l}\text { Tus- } \\
\text { sock } \\
\text { tundra }\end{array}$ & \\
\hline Maintenance respiration factors & M 1 & & & & \\
\hline Sphagnum capillaceum & & 0.009 & b & b & Oechel (1976) \\
\hline Dicranum elongatum & & 0.021 & b & b & Oechel (1976) \\
\hline Polytrichum commune & & 0.009 & b & b & Oechel (1976) \\
\hline Other & & 0.021 & b & b & Oechel (1976) \\
\hline Sphagnum capillaceum & M2 & 1.8 & b & b & Oechel (1976) \\
\hline Dicranum elongatum & & 3.9 & b & b & Oechel (1976) \\
\hline Polytrichum commune & & 1.8 & b & b & Oechel (1976) \\
\hline Other & & 3.9 & b & b & Oechel (1976) \\
\hline Sphagnum capillaceum & M3 & 0.6 & b & b & Oechel (1976) \\
\hline Dicranum elongatum & & 0.6 & b & b & Oechel (1976) \\
\hline Polytrichum commune & & 0.8 & b & b & Oechel (1976) \\
\hline Other & & 0.6 & b & b & Oechel (1976) \\
\hline Sphagnum capillaceum & M4 & 15.0 & b & b & Oechel (1976) \\
\hline Dicranum elongatum & & 15.0 & b & b & Oechel (1976) \\
\hline Polytrichum commune & & 15.0 & b & b & Oechel (1976) \\
\hline Other & & 15.0 & b & b & Oechel (1976) \\
\hline
\end{tabular}

* See Appendix 1 for definitions.

$\dagger$ For explanation of degree of confidence symbols a-d, see Table 2.

TABLE A5. Soil parameters and early season values for the soil compartments and variables for Eriophorum vaginatum tussock tundra at Eagle Creek.

\begin{tabular}{|c|c|c|c|c|c|}
\hline \multirow[b]{2}{*}{ Compartment or variable } & \multirow[b]{2}{*}{$\begin{array}{c}\text { Program } \\
\text { name* }\end{array}$} & \multirow[b]{2}{*}{ Value } & \multicolumn{2}{|c|}{ Confidence $†$} & \multirow[b]{2}{*}{ Reference } \\
\hline & & & $\begin{array}{l}\text { Eagle } \\
\text { Creek }\end{array}$ & $\begin{array}{l}\text { Tussock } \\
\text { tundra }\end{array}$ & \\
\hline Maximum thickness of active layer $(\mathrm{cm})$ & & 60 & a & $\mathrm{b}$ & Chapin et al. (1979) \\
\hline $\begin{array}{l}\text { Bulk density }\left(\mathrm{g} / \mathrm{cm}^{3}\right) \\
\text { Fibric } \\
\text { Hemic } \\
\text { Sapric } \\
\text { Mineral }\end{array}$ & BD & $\begin{array}{l}0.13 \pm 0.04 \\
0.18 \pm 0.10 \\
0.25 \pm 0.05 \\
1.46 \pm 0.47\end{array}$ & $\begin{array}{l}\mathrm{a} \\
\mathrm{b} \\
\mathrm{a} \\
\mathrm{b}\end{array}$ & $\begin{array}{l}\mathrm{b} \\
\mathrm{b} \\
\mathrm{b} \\
\mathrm{c}\end{array}$ & $\begin{array}{l}\text { Chapin et al. (1979) } \\
\text { Chapin et al. (1979) } \\
\text { Chapin et al. (1979) } \\
\text { Chapin et al. (1979) }\end{array}$ \\
\hline $\begin{array}{l}\text { Soil moisture content (g/g dry mass) } \ddagger \\
\text { Fibric } \\
\text { Hemic } \\
\text { Sapric } \\
\text { Mineral }\end{array}$ & & $\begin{array}{l}4.51 \pm 1.19 \\
4.53 \pm 1.45 \\
3.62 \pm 0.83 \\
0.47 \pm 0.05\end{array}$ & $\begin{array}{l}\mathrm{a} \\
\mathrm{b} \\
\mathrm{b} \\
\mathrm{a}\end{array}$ & $\begin{array}{l}b \\
b \\
b \\
b\end{array}$ & $\begin{array}{l}\text { Chapin et al. (1979) } \\
\text { Chapin et al. (1979) } \\
\text { Chapin et al. (1979) } \\
\text { Chapin et al. (1979) }\end{array}$ \\
\hline $\begin{array}{l}\text { Organic carbon content }(\%) \\
\text { Fibric } \\
\text { Hemic } \\
\text { Sapric } \\
\text { Mineral }\end{array}$ & & $\begin{array}{r}43.7 \pm 0.6 \\
41.7 \pm 0.4 \\
41.0 \pm 0.8 \\
5.9 \pm 0.6\end{array}$ & $\begin{array}{l}\mathrm{a} \\
\mathrm{a} \\
\mathrm{a} \\
\mathrm{a}\end{array}$ & $\begin{array}{l}\mathrm{a} \\
\mathrm{a} \\
\mathrm{a} \\
\mathrm{c}\end{array}$ & $\begin{array}{l}\text { Chapin et al. (1979) } \\
\text { Chapin et al. (1979) } \\
\text { Chapin et al. (1979) } \\
\text { Chapin et al. (1979) }\end{array}$ \\
\hline $\begin{array}{l}\text { Organic carbon distribution in profile }(\% \\
\text { Fibric } \\
\text { Hemic } \\
\text { Sapric } \\
\text { Mineral }\end{array}$ & & $\begin{array}{r}18 \\
16 \\
19 \\
7\end{array}$ & $\begin{array}{l}\mathrm{a} \\
\mathrm{a} \\
\mathrm{a} \\
\mathrm{a}\end{array}$ & $\begin{array}{l}\mathrm{c} \\
\mathrm{c} \\
\mathrm{c} \\
\mathrm{c}\end{array}$ & $\begin{array}{l}\text { Everett (1981) } \\
\text { Everett (1981) } \\
\text { Everett (1981) } \\
\text { Everett (1981) }\end{array}$ \\
\hline $\begin{array}{l}\text { Lignin content }(\%) \\
\text { Fibric } \\
\text { Hemic } \\
\text { Sapric } \\
\text { Mineral }\end{array}$ & & $\begin{array}{l}28 \\
22 \\
26 \\
\cdots\end{array}$ & & & $\begin{array}{l}\text { Linkins (1981) } \\
\text { Linkins }(1981) \\
\text { Linkins }(1981) \\
\text { Linkins (1981) }\end{array}$ \\
\hline
\end{tabular}




\section{APPENDIX 2}

TABle A5. Continued.

\begin{tabular}{|c|c|c|c|c|c|}
\hline \multirow[b]{2}{*}{ Compartment or variable } & \multirow[b]{2}{*}{$\begin{array}{c}\text { Program } \\
\text { name* }\end{array}$} & \multirow[b]{2}{*}{ Value } & \multicolumn{2}{|c|}{ Confidence $\dagger$} & \multirow[b]{2}{*}{ Reference } \\
\hline & & & $\begin{array}{l}\text { Eagle } \\
\text { Creek }\end{array}$ & $\begin{array}{c}\text { Tussock } \\
\text { tundra }\end{array}$ & \\
\hline \multicolumn{6}{|l|}{ Cellulose content $(\%)$} \\
\hline $\begin{array}{l}\text { Fibric } \\
\text { Hemic } \\
\text { Sapric } \\
\text { Mineral }\end{array}$ & & $\begin{array}{l}23 \\
22 \\
16 \\
\cdots\end{array}$ & & & $\begin{array}{l}\text { Linkins (1981) } \\
\text { Linkins (1981) } \\
\text { Linkins (1981) } \\
\text { Linkins (1981) }\end{array}$ \\
\hline \multicolumn{6}{|l|}{ Hemicellulose (\%) } \\
\hline $\begin{array}{l}\text { Fibric } \\
\text { Hemic } \\
\text { Sapric } \\
\text { Mineral }\end{array}$ & & $\begin{array}{l}19 \\
13 \\
10 \\
\cdots\end{array}$ & & & \\
\hline \multicolumn{6}{|l|}{ Protein content $(\%)$} \\
\hline $\begin{array}{l}\text { Fibric } \\
\text { Hemic } \\
\text { Sapric } \\
\text { Mineral }\end{array}$ & & $\begin{aligned} 7.19 & \pm 1.06 \S(\mathrm{e}) \\
11.38 & \pm 1.63 \\
14.88 & \pm 1.50 \\
1.50 & \pm 0.44\end{aligned}$ & $\begin{array}{l}\mathrm{a} \\
\mathrm{a} \\
\mathrm{a} \\
\mathrm{a}\end{array}$ & $\begin{array}{l}\mathrm{a} \\
\mathrm{a} \\
\mathrm{a}\end{array}$ & $\begin{array}{l}\text { Chapin et al. (1979) } \\
\text { Chapin et al. (1979) } \\
\text { Chapin et al. (1979) } \\
\text { Chapin et al. (1979) }\end{array}$ \\
\hline \multicolumn{6}{|l|}{ TNC content $(\%)$} \\
\hline Fibric & & $3 \% \|$ & & a & $\begin{array}{l}\text { K. R. Everett } \\
\quad \text { (personal observation) }\end{array}$ \\
\hline $\begin{array}{l}\text { Hemic } \\
\text { Sapric } \\
\text { Mineral }\end{array}$ & & $\begin{array}{l}3 \% \\
3 \% \\
0\end{array}$ & & $\begin{array}{l}\mathrm{a} \\
\mathrm{a}\end{array}$ & \\
\hline
\end{tabular}

* See Appendix 2 for definitions.

$\dagger$ For explanation of degree of confidence symbols a-d, see Table 2.

‡ Initially set to zero until thawed; ARTUS uses water in units of $\mathrm{g} / \mathrm{cm}^{3}$.

$\S$ Protein content calculated from percent nitrogen times 6.25 .

|| Not measured at Eagle Creek; other site average for tussock tundra in Alaska.

TABLE A6. Parameter values to calculate enzyme activities. Values were measured at $20^{\circ} \mathrm{C}$, corrected to $350 \%$ moisture content for tussock and $425 \%$ moisture content in intertussock areas. Values are means \pm SE, $n=64$.

\begin{tabular}{|c|c|c|c|c|}
\hline \multirow[b]{2}{*}{ Maximum rate of decomposition of: } & \multirow[b]{2}{*}{ Value } & \multicolumn{2}{|c|}{ Confidence† } & \multirow[b]{2}{*}{ Reference } \\
\hline & & $\begin{array}{l}\text { Eagle } \\
\text { Creek }\end{array}$ & $\begin{array}{c}\text { Tus- } \\
\text { sock } \\
\text { tundra }\end{array}$ & \\
\hline \multicolumn{5}{|l|}{ Tussock } \\
\hline $\begin{array}{l}\text { Cellulose decomposed by endocellulase } \\
\text { (units } \cdot \mathrm{h}^{-1} \cdot \mathrm{g}^{-1} \text { soil dry mass) }\end{array}$ & $300 \pm 50$ & b & b & Linkins et al. 1983 \\
\hline $\begin{array}{l}\text { Cellulose decomposed by exocellulase (glucose, } \\
\mathrm{mg} \cdot \mathrm{h}^{-1} \cdot \mathrm{g}^{-1} \text { soil dry mass) }\end{array}$ & $43 \pm 12$ & b & b & Linkins et al. 1983 \\
\hline Phosphorus in organic compounds (PNP, $\mathrm{mg} \cdot \mathrm{h}^{-1} \cdot \mathrm{g}^{-1}$ ) & $2.7 \pm 0.8$ & b & $\mathrm{b}$ & Herbein (1981) \\
\hline Protein (amino acid, $\mathrm{mg} \cdot \mathrm{h}^{-1} \cdot \mathrm{g}^{-1}$ soil dry mass) & $0.60 \pm 0.20$ & b & $\mathrm{b}$ & Linkins and Neal (1982) \\
\hline $\begin{array}{l}\text { Chitin ( } n \text {-acetyl glucosamine, } \mathrm{mg} \cdot \mathrm{h}^{-1} \cdot \mathrm{g}^{-1} \\
\text { soil dry mass) }\end{array}$ & $2.5 \pm 0.2$ & b & $\mathrm{c}$ & Linkins and Neal (1982) \\
\hline \multicolumn{5}{|l|}{ Intertussock } \\
\hline $\begin{array}{l}\text { Cellulose decomposed by endocellulase } \\
\text { (units } \cdot h^{-1} \cdot g^{-1} \text { soil dry mass) }\end{array}$ & $200 \pm 42$ & b & $\mathrm{b}$ & Linkins and Neal (1982) \\
\hline $\begin{array}{l}\text { Cellulose decomposed by exocellulase (glucose, } \\
\mathrm{mg} \cdot \mathrm{h}^{-1} \cdot \mathrm{g}^{-1} \text { soil dry mass) }\end{array}$ & $27 \pm 6$ & b & $\mathrm{b}$ & Linkins and Neal (1982) \\
\hline $\begin{array}{l}\text { Phosphorus in organic compounds (PNP, } \mathrm{mg} \cdot \mathrm{h}^{-1} \cdot \mathrm{g}^{-1} \\
\text { soil dry mass) }\end{array}$ & $2.9 \pm 0.3$ & $\mathrm{~b}$ & $\mathrm{~b}$ & Herbein (1981) \\
\hline Protein (amino acids, $\mathrm{mg} \cdot \mathrm{h}^{-1} \cdot \mathrm{g}^{-1}$ soil dry mass) & $0.20 \pm 0.02$ & $\mathrm{~b}$ & b & Linkins and Neal (1982) \\
\hline $\begin{array}{l}\text { Chitin ( } n \text {-acetyl glucosamine, } \mathrm{mg} \cdot \mathrm{h}^{-1} \cdot \mathrm{g}^{-1} \\
\text { soil dry mass) }\end{array}$ & $1.2 \pm 0.01$ & $\mathrm{~b}$ & $\mathrm{~b}$ & Linkins and Neal (1982) \\
\hline
\end{tabular}

† For explanation of degree of confidence symbols a-d, see Table 2. 
TABLE A7. Parameter values to calculate phosphorus cycling.

\begin{tabular}{|c|c|c|c|c|c|}
\hline \multirow[b]{2}{*}{ Parameter and species } & \multirow[b]{2}{*}{ Program name* } & \multirow[b]{2}{*}{ Value } & \multicolumn{2}{|c|}{ Confidence $†$} & \multirow[b]{2}{*}{ Reference } \\
\hline & & & $\begin{array}{l}\text { Eagle } \\
\text { Creek }\end{array}$ & $\begin{array}{l}\text { Tussock } \\
\text { tundra }\end{array}$ & \\
\hline $\begin{array}{l}\text { Phosphorus concentration of rain } \\
(\mathrm{mg} / \mathrm{L})\end{array}$ & POCONTENT & 0.003 & $\mathrm{c}$ & c & G. Marion (personal observation) \\
\hline $\begin{array}{l}\text { Proportion of phosphorus leached from } \\
\text { senesced plant material }\end{array}$ & POLEACH & 0.13 & a & a & Van Cleve and Alexander (1981) \\
\hline Soil organic phosphorus $\left(\mathrm{g} / \mathrm{m}^{2}\right)$ & SOILPORG & & & & \\
\hline $\begin{array}{l}\text { Fibric } \\
\text { Hemic } \\
\text { Sapric } \\
\text { Mineral }\end{array}$ & & $\begin{array}{l}3.5 \\
16 \\
45 \\
65\end{array}$ & $\begin{array}{l}\mathrm{a} \\
\mathrm{a} \\
\mathrm{a} \\
\mathrm{a}\end{array}$ & $\begin{array}{l}\mathrm{b} \\
\mathrm{b} \\
\mathrm{b} \\
\mathrm{b}\end{array}$ & $\begin{array}{l}\text { Chapin and Van Cleve }(1978) \\
\text { Chapin and Van Cleve }(1978) \\
\text { Chapin and Van Cleve }(1978) \\
\text { Chapin and Van Cleve }(1978)\end{array}$ \\
\hline Soil inorganic phosphorus $\left(\mathrm{g} / \mathrm{m}^{2}\right)$ & SLINORGPO & & & & \\
\hline Fibric & & 0.0083 & $\mathrm{~b}$ & $\mathrm{c}$ & $\begin{array}{l}\text { S. A. Barkley and J. Kellog } \\
\text { (personal observation) }\end{array}$ \\
\hline Hemic & & 0.0111 & $\mathrm{~b}$ & c & $\begin{array}{l}\text { S. A. Barkley and J. Kellog } \\
\text { (personal observation) }\end{array}$ \\
\hline Sapric & & 0.0075 & b & c & $\begin{array}{l}\text { S. A. Barkley and J. Kellog } \\
\text { (personal observation) }\end{array}$ \\
\hline Mineral & & 0.0059 & b & $\mathrm{c}$ & $\begin{array}{l}\text { S. A. Barkley and J. Kellog } \\
\text { (personal observation) }\end{array}$ \\
\hline $\begin{array}{l}\text { Soil exchangeable inorganic phos- } \\
\text { phorus }\left(\mathrm{g} / \mathrm{m}^{2}\right)\end{array}$ & EXCHANGPO & & & & \\
\hline Fibric & & 0.3 & $\mathrm{~d}$ & d & estimate \\
\hline Hemic & & 0.7 & d & d & estimate \\
\hline Sapric & & 1.0 & $\mathrm{~d}$ & d & estimate \\
\hline Mineral & & 2.0 & d & d & estimate \\
\hline $\begin{array}{l}\text { Phosphorus uptake rate of roots } \\
\qquad\left(g \cdot g^{-1} \cdot d^{-1}\right)\end{array}$ & PUPCAP & & & & \\
\hline Betula nana & & 8.1 & $\mathrm{~b}$ & $\mathrm{~b}$ & Chapin and Tryon (1982) \\
\hline Vaccinium uliginosum & & 2.3 & $\mathrm{~b}$ & $\mathrm{~b}$ & Chapin and Tryon (1982) \\
\hline Ledum palustre & & 1.2 & $\mathrm{~b}$ & b & Chapin and Tryon (1982) \\
\hline Vaccinium vitis-idaea & & 4.9 & b & b & Chapin and Tryon (1982) \\
\hline Eriophorum vaginatum & & 23.5 & $\mathrm{~b}$ & $\mathrm{~b}$ & Chapin and Tryon (1982) \\
\hline Carex aquatilis & & 15.0 & $\mathrm{~b}$ & b & Chapin and Tryon (1982) \\
\hline $\begin{array}{l}\text { Mycorrhizal factor in unsaturated } \\
\text { soils } \ddagger\end{array}$ & PMYCO & & & & \\
\hline Betula nana & & 57 & a & $\mathrm{d}$ & $\begin{array}{l}\text { Calculated, see text } \\
\text { (Phosphorus cycling) }\end{array}$ \\
\hline Vaccinium ulinginosum & & 60 & a & $\mathrm{d}$ & $\begin{array}{l}\text { Calculated, see text } \\
\text { (Phosphorus cycling) }\end{array}$ \\
\hline Ledum palustre & & 70 & a & $\mathrm{d}$ & $\begin{array}{l}\text { Calculated, see text } \\
\text { (Phosphorus cycling) }\end{array}$ \\
\hline Vaccinium vitis-idaea & & 4.3 & a & $\mathrm{d}$ & $\begin{array}{l}\text { Calculated, see text } \\
\text { (Phosphorus cycling) }\end{array}$ \\
\hline Carex aquatilis & & 1 & & & \\
\hline Eriophorum vaginatum & & 1 & & & \\
\hline
\end{tabular}

* See Appendix 1 for definitions.

† For explanation of degree of confidence symbols a-d, see Table 2.

$\ddagger$ Mycorrhizal factor $=1$ in saturated soils. 
TABLE A8. Parameter values to calculate major driving environmental variables, heat exchange, and water balance. Ranges of values are given in parentheses.

\begin{tabular}{|c|c|c|c|c|c|}
\hline \multirow[b]{2}{*}{ Equation } & \multirow[b]{2}{*}{ Program name* } & \multirow[b]{2}{*}{ Value } & \multicolumn{2}{|c|}{ Confidencet } & \multirow[b]{2}{*}{ Reference } \\
\hline & & & $\begin{array}{l}\text { Eagle } \\
\text { Creek }\end{array}$ & $\begin{array}{l}\text { Tussock } \\
\text { tundra }\end{array}$ & \\
\hline \multicolumn{6}{|l|}{ Climate } \\
\hline $\begin{array}{l}\text { Annual maximum daily solar } \\
\text { irradiance }\left(\mathrm{MJ} \cdot \mathrm{m}^{-2} \cdot \mathrm{d}^{-1}\right)\end{array}$ & SMAX & 22 & a & b & $\begin{array}{l}\text { L. Stuart and P. C. Miller } \\
\text { (personal observation) }\end{array}$ \\
\hline $\begin{array}{l}\text { Annual minimum daily solar } \\
\text { irradiance }\left(\mathrm{MJ} \cdot \mathrm{m}^{-2} \cdot \mathrm{d}^{-1}\right)\end{array}$ & SMIN & 0 & a & $\mathrm{b}$ & $\begin{array}{l}\text { L. Stuart and P. C. Miller } \\
\text { (personal observation) }\end{array}$ \\
\hline $\begin{array}{l}\text { Annual mean air temperature } \\
\left({ }^{\circ} \mathrm{C}\right)\end{array}$ & TMEAN & -8 & $\mathrm{a}$ & $\mathrm{c}$ & Haugen and Brown (1978) \\
\hline $\begin{array}{l}\text { Annual temperature fluctuation } \\
\text { about the mean }\left({ }^{\circ} \mathrm{C}\right)\end{array}$ & TAMP & 23 & a & $\mathrm{c}$ & \\
\hline Total daily wind passage $(\mathrm{km} / \mathrm{d})$ & WIND & $(96-216)$ & b & $\mathrm{c}$ & $\begin{array}{l}\text { L. Stuart and P. C. Miller } \\
\text { (personal observation) }\end{array}$ \\
\hline Surface albedo (ratio) & ALBEDO & $0.18(0.10-0.25)$ & a & $\mathrm{b}$ & $\begin{array}{l}\text { L. Stuart and P. C. Miller } \\
\text { (personal observation) }\end{array}$ \\
\hline Precipitation $(\mathrm{mm} / \mathrm{d})$ & PRECIP & $(0.5-10.5)$ & b & $\mathrm{c}$ & $\begin{array}{l}\text { L. Stuart and P. C. Miller } \\
\text { (personal observation) }\end{array}$ \\
\hline Relative humidity (ratio) & RH & $(0.6-1.0)$ & b & $\mathrm{c}$ & $\begin{array}{l}\text { L. Stuart and P. C. Miller } \\
\text { (personal observation) }\end{array}$ \\
\hline Relative overcast skies (ratio) & FOV & $(0.0-1.0)$ & b & c & $\begin{array}{l}\text { L. Stuart and P. C. Miller } \\
\text { (personal observation) }\end{array}$ \\
\hline \multicolumn{6}{|l|}{ Soil water } \\
\hline $\begin{array}{l}\text { Maximum possible soil water } \\
\text { content }\left(\mathrm{g} / \mathrm{cm}^{3}\right)\end{array}$ & THETAMAX & 0.9 & a & b & $\begin{array}{l}\text { S. A. Barkley and J. Kellogg } \\
\text { (personal observation) }\end{array}$ \\
\hline Field capacity $\left(\mathrm{g} / \mathrm{cm}^{3}\right)$ & FIELDCAP & 0.6 & a & b & $\begin{array}{l}\text { S. A. Barkley and J. Kellogg } \\
\text { (personal observation) }\end{array}$ \\
\hline $\begin{array}{l}\text { Air-dry soil water content } \\
\left(\mathrm{g} / \mathrm{cm}^{3}\right)\end{array}$ & THETAMIN & 0.1 & a & b & $\begin{array}{l}\text { S. A. Barkley and J. Kellogg } \\
\text { (personal observation) }\end{array}$ \\
\hline
\end{tabular}

* See Appendix 1 for definitions.

$\dagger$ For explanation of degree of confidence symbols a-d, see Table 2. 